\title{
Development Impacts of Irregular Migration: A Study from a Central Province in Vietnam
}

\author{
By
}

Hang Thi Trinh

Student ID: 300343601

A 120-point thesis submitted to Victoria University of Wellington, as partial fulfilment of requirements for the degree of

\section{Master of Development Studies}

School of Geography, Environmental and Earth Sciences Supervisor: Dr. Polly Stupples

March, 2017 
This page is intentionally left blank 


\begin{abstract}
Migration is often viewed negatively in development policy terms, and much understandings of migration often portray it as a threat to social security in destination countries, however, the sustainable livelihood approach presents migration as a livelihoods strategy, suggesting that policy should, instead, support human mobility. In the current context where regular labour migration offers various consequences resulting in both positive and negative impacts, irregular labour migration, though complex because of its undocumented nature, has become the choice of many unskilled and low-skilled workers from Vietnam. This study employs a case-study qualitative approach to look at the case of irregular migrant workers from a central province of Vietnam migrating overseas for economic purposes. It applies the New Economics of Labour Migration theory and the Sustainable Livelihoods Approach and brings together their shared premise of viewing migration as a household calculated strategy to sustain rural livelihoods, to explore whether irregular migration can be a sustainable livelihood strategy for the rural people of Ha Tinh province. The study finds that irregular labour migration is a household calculated strategy and, similar to regular migration, it brings about social and economic benefits that affect the migrants, their families and home communities. Although such migration is complex and vulnerable, it is well thought through by migrants and fits in the context of rural Ha Tinh as a flexible, quick and convenient strategy to gain income for the rural poor. The research also finds that the local people have established their own supporting networks and found their own ways to mitigate the risks and ensure their irregular migration is successful in terms of economic gains. The combination of an economic migration theory and a livelihood approach offers this research an in-depth discussion on the complexity of irregular labour migration and its impacts on various aspects of social and economic development.
\end{abstract}

Keywords: development, irregular migration, labour migration, sustainable rural livelihoods, Vietnam. 
This page is intentionally left blank 


\section{Acknowledgements}

This thesis is dedicated to two women of Ha Tinh who are dear to me - my grandmother, whom I last saw during my time in the field, and my mother, whose efforts to maintain her health while I am away, fuelled me with determination to finish this research.

I am grateful to my research participants who have welcomed me into their homes and offered me their honesty and life stories. This research would not be possible without the genuine sharing, support and trust that they have rendered, and for that, I cannot thank them enough.

To my supervisor, Dr. Polly Stupples, I am incredibly thankful for your dedication to quality and commitment to guiding my research. I thank you for never doubting my ability; your guidance, knowledge, patience and consistency motivated me during the write-up of this thesis.

I am also grateful to Professor John Overton, the Director of the Masters in Development Studies programme at VUW. His teaching and sharing of in-depth knowledge of development inspired me throughout the time of my study, and I believe, will further guide my future work after the completion of this degree.

I appreciate the kind staff members of the School of Geography, Environmental and Earth Sciences for their support that have made my thesis year so enjoyable. To my family and friends in Vietnam, the pursuit of this academic journey would not have been fulfilled without your unfailing encouragement, love and support. Thank you for always and forever being the place where I belong.

To my classmates of Development Studies - Phonexay, Visal, Jasmin, Hawa, Sila, Ezzy and Sam, I could not have done this without you! Your daily dose of inspiration, motivation, understanding and support means so much to me. I thank you for being my companions in development studies; your sharing and understanding, often in times when I am in doubt, or when I lost my sanity, always lifted my spirit and motivated me to get back up. I have become a better 
person knowing and learning from you, and I hope the bond that we have built over the past two years continues to grow stronger into our future.

To MFAT/ NZAID, who has kindly sponsored my study at VUW and provided excellent support during the past two years, I am forever thankful for this opportunity. 


\section{Acronyms}

\begin{tabular}{|c|c|}
\hline $\mathrm{ADB}$ & Asian Development Bank \\
\hline AEC & ASEAN Economic Community \\
\hline ASEAN & Association of South East Asia Nations \\
\hline CPV & Communist Party of Vietnam \\
\hline DFID & Department for International Development \\
\hline DOLISA & Department of Labour, Invalids and Social Affairs \\
\hline EWEC & East-West Economic Corridor \\
\hline FAO & Food and Agriculture Organization \\
\hline GDP & Gross Domestic Product \\
\hline GMS & Greater Mekong Sub-region \\
\hline GNI & Gross National Income \\
\hline GSO & General Statistics Office of Vietnam \\
\hline IDS & Institute of Development Studies \\
\hline IFAD & International Fund for Agricultural Development \\
\hline ILO & International Labour Organisation \\
\hline IMF & International Monetary Fund \\
\hline IOM & International Organization for Migration \\
\hline MARD & Ministry of Agriculture and Rural Development \\
\hline MNP & Movement of Natural Persons \\
\hline MOET & Ministry of Education and Training \\
\hline MOLISA & Ministry of Labour, Invalids and Social Affairs \\
\hline MOU & Memorandum of Understanding \\
\hline MRA & Mutual Recognition Arrangements \\
\hline NA & National Assembly \\
\hline NELM & New Economics of Labour Migration \\
\hline ODA & Official Development Assistance \\
\hline OECD & $\begin{array}{l}\text { Organization for Economic Co-operation and } \\
\text { Development }\end{array}$ \\
\hline SEZ & Special Economic Zones \\
\hline SLA & Sustainable Livelihood Approach \\
\hline SRV & Socialist Republic of Vietnam \\
\hline TPP & Trans Pacific Partnership \\
\hline UN & United Nations \\
\hline UNDP & United Nations Development Programme \\
\hline USD & United States Dollar \\
\hline VND & Vietnam Dong \\
\hline VUW & Victoria University of Wellington \\
\hline WTO & World Trade Organisation \\
\hline
\end{tabular}


This page is intentionally left blank 


\section{Table of Contents}

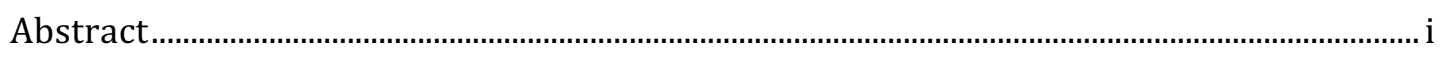

Acknowledgements............................................................................................................... iii

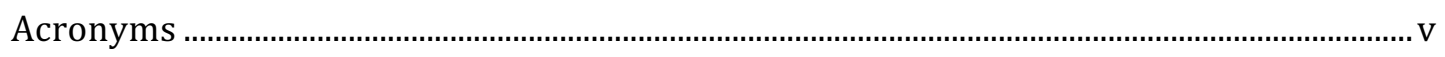

Table of Contents .............................................................................................................. vii

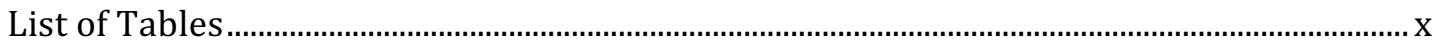

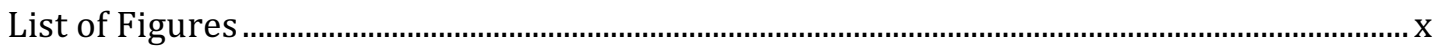

List of Boxes ............................................................................................................................ $\mathrm{X}$

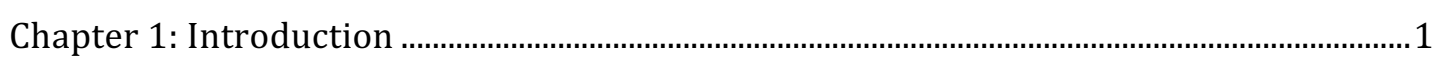

1.1. Thesis background...........................................................................................

1.1.1. Irregular migration from Vietnam .....................................................................

1.1.2. Vietnamese irregular economic migration - definition of a complex

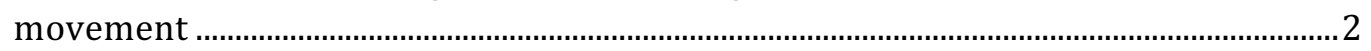

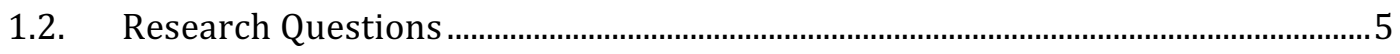

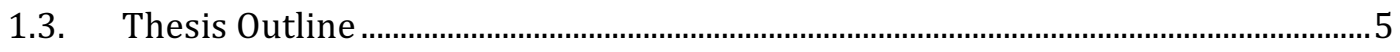

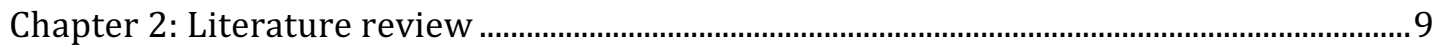

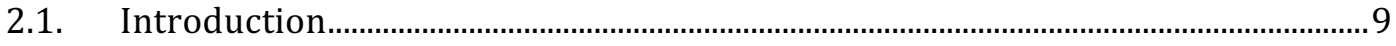

2.2. Migration and Development in the global context - a paradigm shift..................

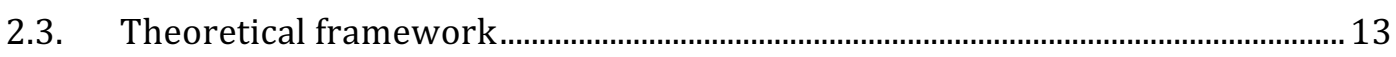

2.3.1. Maximizing income - from individualism to the household decision....... 13

2.3.2. Integrating NELM with the sustainable livelihood approach to understand migration as a household calculated livelihood strategy ......................... 16

2.4. Irregular migration in the global context .................................................................. 20

2.5. Migration and Development in Vietnam ................................................................ 21

2.5.1. Vietnamese regular labour migration ........................................................... 21

2.5.2. Gender and migration in Vietnam .................................................................. 23

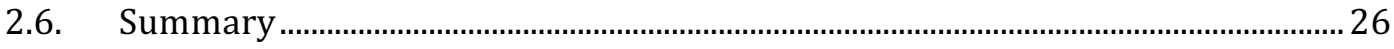

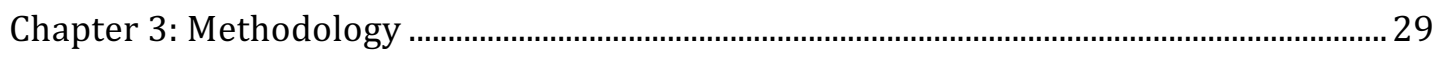

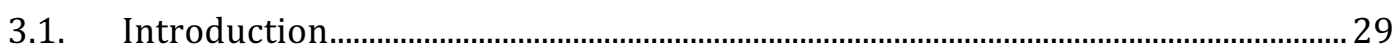

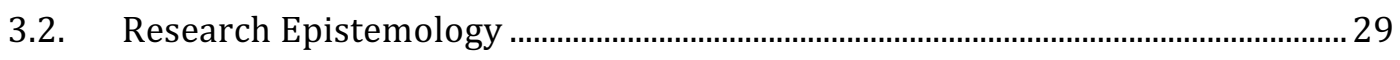

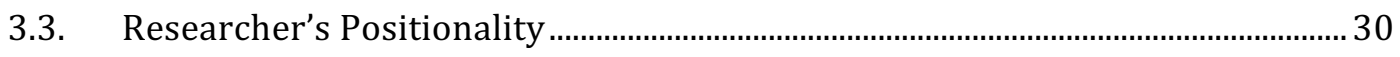

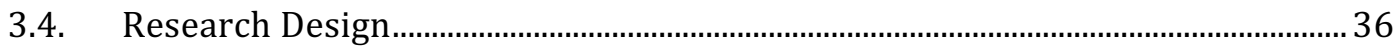

3.5. Qualitative research and case study approach ...................................................... 38

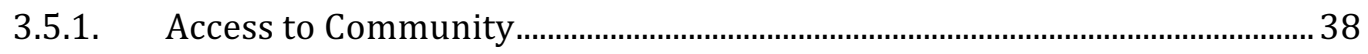

3.5.2. Sampling and Participant Selection ................................................................ 40 


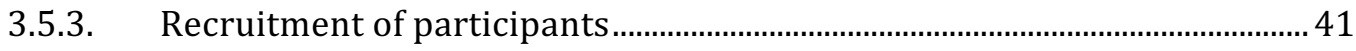

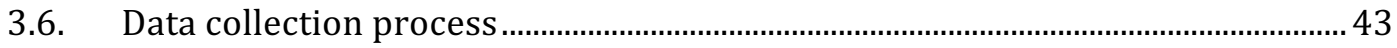

3.6.1. Pre-departure preparation.................................................................................. 43

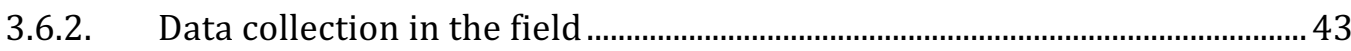

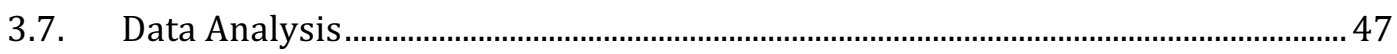

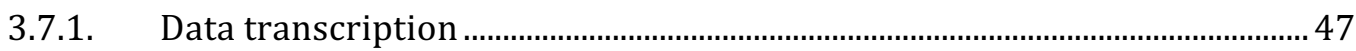

3.7.2. Data Analysis ............................................................................................. 47

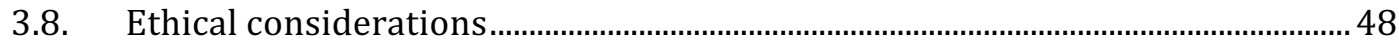

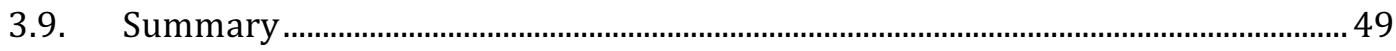

Chapter 4: Context................................................................................................................... 51

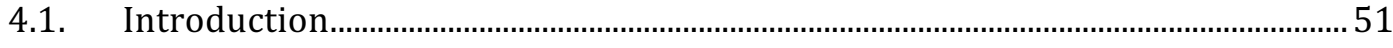

4.2. Vietnam Country Profile........................................................................................ 51

4.2.1. Geographic and demographic features ..................................................... 51

4.2.2. General economic features........................................................................... 54

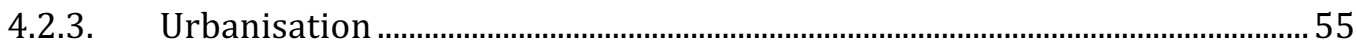

4.2.4. Basic political features ………………........................................................... 55

4.2.5. Strengths and vulnerabilities in the Vietnamese agricultural context......57

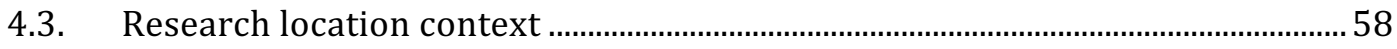

4.3.1. Ha Tinh's geographic and demographic features ............................................ 58

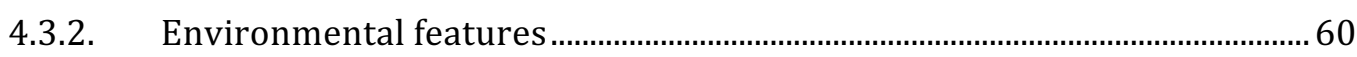

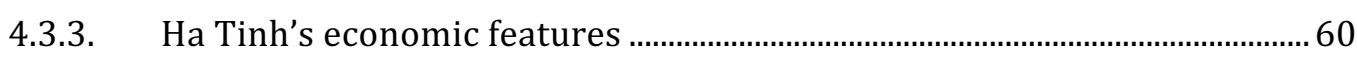

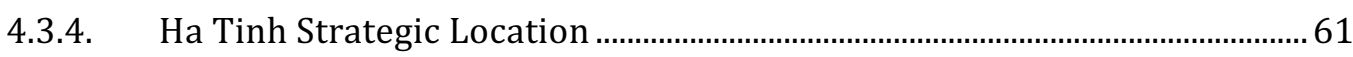

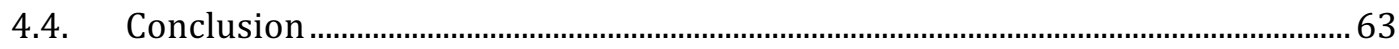

Chapter 5: Irregular Migration as a Livelihood Strategy ..........................................................65

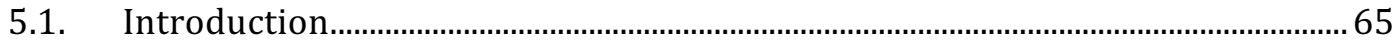

5.2. Categories of irregular migrant workers according to age and motivation ..... 66

5.3. How is irregular migration a livelihood strategy? ................................................... 70

5.3.1. Irregular migration as a means to diversify family income sources...........70

5.3.2. A change of perception about rural farm work ................................................ 73

5.3.3. The old poverty and the new prospect ............................................................ 75

5.3.4. The role of education in the rural area ……………………………………...... 76

5.3.5. Keeping a low-profile life - how people make irregular migration work79

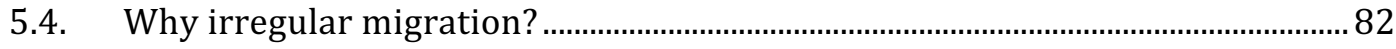

5.4.1. The differences between regular and irregular labour migration............... 82

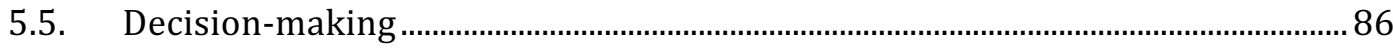

5.5.1. The poverty push and the economic development pull ……........................ 86

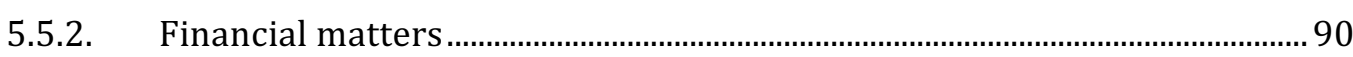


5.5.3. Social network 97

5.5.4. Proximity and the precariousness of irregular migration.......................... 101

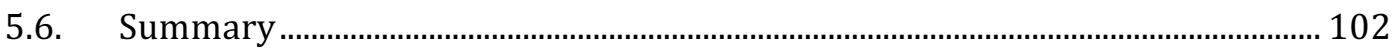

Chapter 6: The development impacts of irregular labour migration .................................. 105

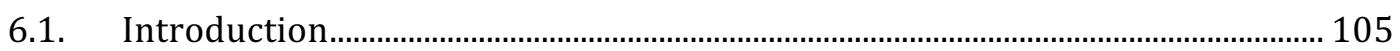

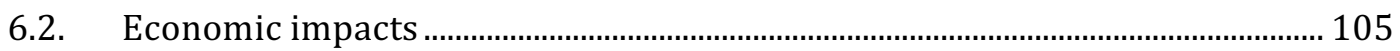

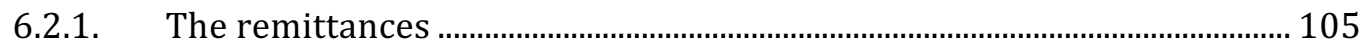

6.2.2. Household improvement ............................................................................. 107

6.2.3. The accumulation of economic capital and a more dynamic local economy

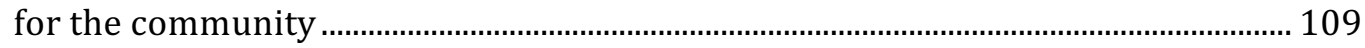

6.3. Children's education as social upward mobility for future generations......... 111

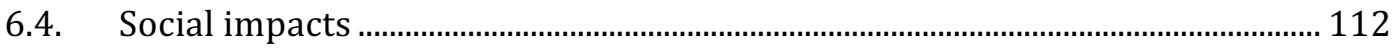

6.4.1. The family calculated livelihood strategy ……………................................... 112

6.4.2. The agency of the self-motivated irregular migrant workers.................... 113

6.4.3. Irregular migration and gender relations..................................................... 117

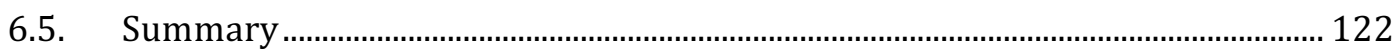

Chapter 7: Irregular migration, migration theory and sustainable rural livelihoods... 125

7.1. Revisiting the research questions ........................................................................ 125

7.2. Discussion of research findings ....................................................................... 126

7.2.1. Irregular migration and the New Economics of Labour Migration theory 127

7.2.2. Irregular labour migration and sustainable livelihoods ............................ 129

7.3. Research limitations ............................................................................................. 134

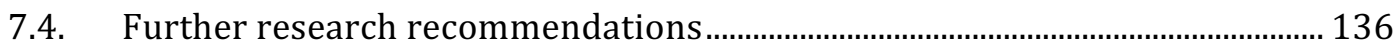

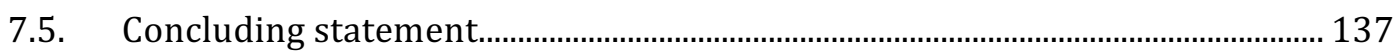

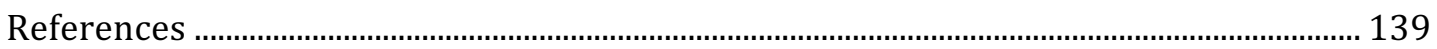

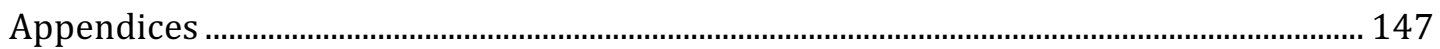

Appendix 1: Participant information sheet (in English) ................................................... 147

Appendix 2: Participant information sheet (in Vietnamese)............................................. 150

Appendix 3: Interview consent form (in English) ............................................................... 153

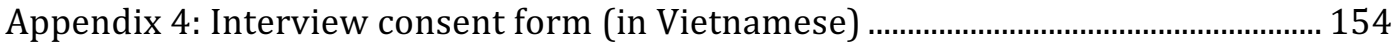

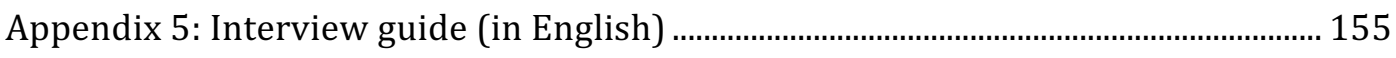

Appendix 6: Interview guide (in Vietnamese) ……………............................................. 157

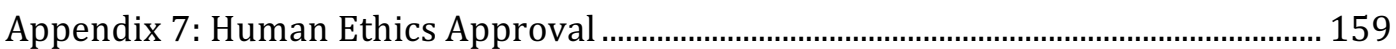




\section{List of Tables}

Table 1: Research methods and tools used during fieldwork ................................................ 37

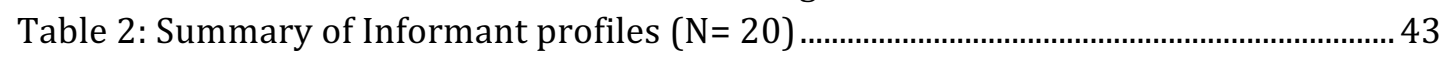

Table 3: Category of irregular migrants divided by age groups.............................................69

Table 4: The household cost and benefit analysis .................................................................... 89

\section{List of Figures}

Figure 1: The sustainable livelihood framework ……............................................................ 18

Figure 2: Administrative Map of Vietnam.......................................................................... 53

Figure 3: Map of Ha Tinh ......................................................................................................... 59

Figure 4: Map of the Third Thai-Lao Friendship Bridge connecting to Ha Tinh ................ 62

Figure 5: The road that runs along one of the villages ......................................................... 72

Figure 6: Children helping out with farm work: herding buffalo. ....................................... 78

Figure 7: Ha Tinh's DOLISA brochure on the joint labour export programme between

Vietnam and South Korea...................................................................................................... 84

Figure 8: The push and pull diagram of irregular migration ................................................ 87

Figure 9: Sweet potatoes and cassava field ........................................................................... 91

Figure 10: A small farm of pigs and chickens established by the loan from the local financial support programme .......................................................................................... 94

Figure 11: A house being built in the village.................................................................. 108

Figure 12: Mapping irregular migration on to the sustainable livelihood framework 133

\section{List of Boxes}

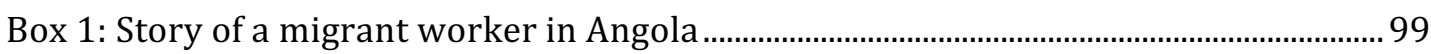

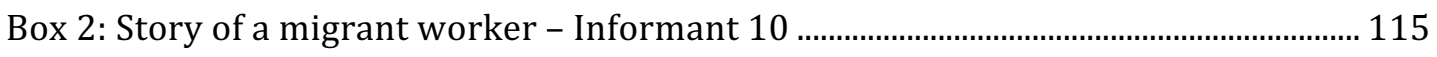

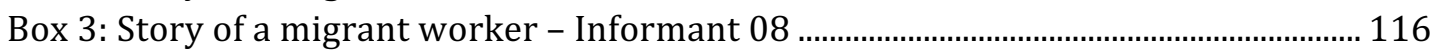




\section{Chapter 1: Introduction}

\subsection{Thesis background}

\subsubsection{Irregular migration from Vietnam}

Recently, there has been a movement of independent and unofficial Vietnamese migrant workers going overseas to seek economic employment (ILO Vietnam, 2015). This movement is potentially exposed to exploitation, discrimination and lack of legal protection due to the undocumented nature of the movement (ibid.). Such movement is categorised as irregular labour migration and it has reportedly increased in scale.

Attempts within the region to open up official labour migration for growth and development have enabled the movement of people within the region, but only regulate certain forms of migrant labour. To start with, within the ASEAN ${ }^{1}$ region, in 2007, the Member States of the ASEAN collectively signed the Agreement on the Movement of Natural Persons (MNP Agreement), bearing the ambition to transform ASEAN into an economic region with free movements of goods, services, investment, skilled labour, and freer flow of capital (Fukunaga \& Ishido, 2015; Huelser \& Heal, 2014). Through the Mutual Recognition Arrangements (MRAs) ${ }^{2}$, high-skilled workers will be provided with the freedom of movement and rights to work across the region. The MRAs apply for professionals in eight fields - accountancy, engineering, surveying, architecture, nursing, medical services, dental services and tourism (ADB \& ILO, 2014). The realization of the MNP Agreement promises greater potential for growth in the region, hoping to make possible an ASEAN Economic Community (AEC) of economic integration and free flow of skilled labour, economic opportunities and wealth (ibid.).

\footnotetext{
${ }^{1}$ ASEAN: Association of South East Asia Nations including Brunei, Cambodia, Indonesia, Laos, Malaysia, Myanmar, Philippines, Singapore, Thailand and Vietnam.

2MRA: Mutual Recognition Arrangement. An MRA enables the authorised, licensed or certified qualifications of professionals which are recognized by the authorities in their home country to be mutually recognized by other ASEAN Member States who are signatories to the MRA. MRAs are not expected to override local laws (ASEAN, n.d.).
} 
Since the establishment of the MNP agreement, ASEAN Member States have actively developed their legal frameworks and infrastructure towards integration in 2015 (ASEAN, 2012). ASEAN efforts under the established MRAs were viewed as an "interesting movement" (Fukunaga, 2015, p. 1), however the movement of regulated professions was found to be not easy due to the differences in underlying legal frameworks, education systems and quality standards, as well as the hesitation of established constituents such as professional associations (ibid.). While the MNP agreement itself has limitations in conditioning the free flow of skilled labour within ASEAN nations, its silence on the regulated liberalization of unskilled and low-skilled labour mobility could lead to the rise of an irregular, unofficial and undocumented labour movement within ASEAN countries, given that citizens of ASEAN member states can move freely within the region without applying for visas from countries of destination and stay for a period of 30 days. That said, the issue of an irregular, undocumented and lowskilled labour movement within ASEAN has been neglected by policy-makers.

According to the Vietnam International Labour Organisation (ILO Vietnam), irregular migration falls outside the parameters of any memorandum of understanding (MoU) on labour migration cooperation between countries; and is not facilitated by legal recruitment agencies. ILO's report in 2015 on Vietnamese migrant workers listed 20 official MoUs between Vietnam and other labour receiving countries, yet actual data from their household survey showed 60 countries where migrants travel to work (ILO Vietnam, 2015). Apparently, the type of undocumented movements within, but not limited to, the ASEAN nations have been recognized and viewed by ILO Vietnam as an on-going trend with increasing numbers of Vietnamese workers opting for irregular migration.

\subsubsection{Vietnamese irregular economic migration - definition of a complex movement}

Irregular migration is complex and hard to define (Duvell, 2006 cited in Castles, Cubas, Kim, \& Ozkul, 2012, p. 117; Koser, 2009) due in part to the undocumented nature of movement involved (Castles et al., 2012). Therefore it is important to define in detail the type of irregular migration with which this thesis is concerned. Within the scope of my study, I would like to use the term "irregular economic 
labour migration" to target the specific type of irregular migration that my thesis seeks to unpack.

Firstly, irregular migration, according to the International Organization for Migration (IOM), is "movement that takes place outside the regulatory norms of the sending, transit and receiving countries" (IOM, 2015). In a more detailed description, Castles et al. (2012, p. 117) explains irregular migration as "people entering and living in a country of which they are not citizens, in violation of its immigration laws and regulations". Many migrants enter a country legally but become irregular by staying longer than permitted or by working without permission (Castles et al., 2012).

Thirdly, Chiswick (2008) defines the term "economic migrants" as those who move from one place of work and residence to another, either within a country or across international boundaries, primarily because of their own economic opportunities. The motivations of economic migrants are distinct from those of refugees and those who move as dependents of other emigrants. In his detailed description of economic migrants, Chiswick described migrants who move for economic opportunities as "tending, on average, to be more able, ambitious, aggressive, entrepreneurial, and healthier" than similar individuals who decided to stay in their place of origin. In short, economic migrants tend to consider their movement on the basis of their skills, health and other characteristics, meaning that they are more healthy, skilful, more dynamic and motivated as well as more driven by the favourable selectivity of labour markets than other types of migrants (Chiswick, 2008).

In the case of Vietnam, some of the literature on Vietnamese labour migration has referred to "irregular migration" as the contract-quitting and/or visa overstaying of migrant workers who went to certain countries through Vietnamese official labour export programmes (Bélanger, Ueno, Hong, \& Ochiai, 2011; Dang, 2008). In 2015, ILO Vietnam made the case that Vietnamese undocumented migration comprised those who migrated to other countries legally with a tourist-visa status to become irregular migrant workers (ILO Vietnam, 2015). ILO Vietnam called this trend "labour migration through unofficial channels" (ibid.), given the "official channels" being legalized serviced governmental and private labour 
export agencies in the country who send trained labourers overseas to work through labour contracts.

This thesis adopts ILO Vietnam's and Chiswick's description of "labour migration through unofficial channels" and "economic migrants" and offers a specific term, "Vietnamese irregular economic migration", to study cases of migrants from a Vietnamese central province travelling (legally) abroad and becoming irregular by working without permission for economic purposes.

ILO Vietnam suggests that Vietnamese irregular migration has become more complex and varied in recent years with the increasing number of migrants and the multiplying of countries of destination; yet there has been a lack of information and understanding of irregular labour migration in Vietnam (ILO Vietnam, 2015). Thus, the identification of the specific, newly-emerging type of irregular migration from Vietnam, as well as the study of its development impacts on the migrants, their families and communities in the place of origin becomes important. This thesis seeks to address the scant literature on the complexity of irregular migration as a development phenomenon in Vietnam and to offer its findings as a contribution to a better understanding of irregular economic labour migration.

This thesis aims to explore the experience of returned irregular migrant workers from a central province of Vietnam, who have migrated without using the services of any legalised state-owned or private labour recruitment agencies. In doing so, the research seeks to explore the migrants' perspective to gain insights into their migratory experience, the range of reasoning that influenced their decisionmaking and how the process brought about changes that affect the livelihoods of the irregular migrant workers, their families and communities of origin. Adopting the explanation of labour migration of the New Economics of Labour Migration theory, in combination with the sustainable livelihood framework, my research aims to examine whether irregular labour migration can be a choice of livelihood strategy for the local people in order to sustain their rural livelihoods. Under this light, the research also assesses the extent to which the consequences of the migration process produce an impact on national and rural development in the place of origin. 


\subsection{Research Questions}

In order to examine Vietnamese irregular economic labour migration and its development impacts, I adopt a qualitative case study approach for my thesis. The combination of the New Economics of Labour Migration theory and the sustainable livelihood approach provides me with an appropriate theoretical framework. In addition, I employ three main research questions to guide my thesis. My questions explore irregular migration and seek to understand both how such migration took place and the reasons why, in consideration of local people's livelihood situation and environmental settings. I also asked questions regarding the impacts that migration brings as well as the change of dynamics in the family and the community of origin after the temporary migration. The main questions were as follow:

Main question:

What are the development impacts of the process of irregular economic labour migration on the migrant workers, their family members and community in their place of origin?

Sub question:

(1). How does the process of irregular migration happen and how is irregular economic labour migration a choice for livelihood diversification in the context of rural Ha Tinh?

(2). What are the range of reasons that shape the migratory decisions for the local people in the case of irregular economic labour migration?

\subsection{Thesis Outline}

This thesis consists of seven chapters.

Chapter One introduces the topic and background of the thesis with a brief introduction of the issues framing this study. It also identifies the specific type of irregular migration from Vietnam that this thesis is concerned with. I also outline my research questions that guided my process of data collection. 
Chapter Two is a literature review which provides an analysis of key literature related to the topic of migration and development that informs the research discussion. The chapter also analyses the New Economics of Labour Migration theory and the sustainable livelihood approach framework and brings together their shared premises to study irregular labour migration as a calculated household strategy to sustain rural livelihoods. The chapter also presents a section on migration and development in the context of Vietnam.

Chapter Three outlines the research methodology. This research adopts social constructivism as the epistemology that guides the conduct of the research and employs three main methods of semi-structured in-depth interviews, participation observation and the use of field notes to generate research data. Other methods of data collection include data recording, photography and the collection of supporting documents during fieldwork. The chapter also discusses critically my positionality and ethical considerations.

Chapter Four provides a context description of the research location. Specifically, the context chapter presents the social, economic and political characteristics of Vietnam and moves on to a specific overview of the province of Ha Tinh's agricultural, environmental and economic situation. This section also details the strategic geographical location of Ha Tinh, being close to the border between Vietnam, Thailand and Laos, which informs the discussion of the research: $\mathrm{Ha}$ Tinh's location could be a reason why there have been an increasing number of local people crossing the border unofficially. The analysis of the environment of Ha Tinh also has an influence, detailed through the finding that rural people have gradually lost their interest in farming due to low productivity and harsh climatic conditions.

Chapters Five and Six present the research findings and discussion. Chapter Five explores two research questions regarding how irregular migration has become a livelihood strategy and the reasons that inform the migratory decision of the research participants. Chapter Six offers findings and analysis of irregular migration touching on a wide range of aspects such as social relations, economic betterment and gender relations. 
The final Chapter of this research discusses the findings in relation to the theoretical framework. In particular, it discusses the economic impacts of irregular labour migration as predicted by the New Economics of Labour Migration theory and the way remittances are used to sustain rural livelihoods. The chapter also acknowledges the limitations of this research and suggests several recommendations for further research. 
This page is intentionally left blank 


\section{Chapter 2: Literature review}

\subsection{Introduction}

This chapter reviews the literature and describes the theoretical framework that is relevant for this research into Vietnamese irregular economic migration. The first section gives a brief overview of the different conceptual trajectories of the migration and development relationship. Here it is necessary to look at historical shifts in the migration and development paradigm in order to locate Vietnam's position in the global picture in the upcoming chapters. This is followed by a discussion on the theoretical framework of the research that links irregular economic migration with sustainable livelihoods. The focus then moves to "irregular economic migration", a term used here to explore the new, unregulated strand of temporary economic migration from Vietnam to other countries. The literature that describes irregular migration in negative terms is discussed, as is the broader New Economics of Labour Migration (NELM) theory. NELM is used to unpack the situation of irregular economic migration and to move beyond the negative contention and argue that this type of migration has its positive development impacts on migrants and their livelihoods.

\subsection{Migration and Development in the global context - a paradigm shift}

Debates about the relationship between migration and development have been ongoing for decades with a strong focus on the economic aspect of migration with both optimistic and pessimistic contentions (Castles, 2009; DeWind \& Ergun, 2013). The main concern was whether migration would lead to development in countries of origin, or hinder such development (Castles \& Miller, 2009). The debates on migration and development in both academic and policy research were described by Hein de Haas (2008) as the "back and forth swing of a pendulum" - shifting from optimism in the 1950s-60s to pessimism in the 1970s then recently back to optimism (Castles, 2009; De Haas, 2008). 
During the 1950s and 1960s, under the influence of neo-classical and modernization theories, development economists described labour migration as "an integral part of modernization" (Castles, 2009). Migration was believed to generally have a positive impact on the development process in sending societies (De Haas, 2008). Academic research and policy during this period was focused on the reciprocal effects of migration and development, holding that migration would solve labour surpluses and unemployment in origin countries and lead to development through migrant remittances that improve productivity and incomes (Castles \& Miller, 2009, p. 50). Castles (2009, p. 4) described the "positive view" about migration in the 1950s and 1960s as a "virtuous circle": it started with the beginning of development in poor countries that stipulated migration as the mechanism to enhance development. The idea was that migration would help reach income equilibrium through remittances, eliminating the 'root causes' of migration so people no longer had the need to migrate (Castles, 2009).

The pessimistic view about migration started to be developed a decade or two later when migration and its positive linkage with development was contested by a historical-institutional approach that viewed it instead as a "vicious circle" (Castles, 2009; De Haas, 2008). According to De Haas, most migration pessimists drew on structuralist social theories (namely neo-Marxist, dependency and world systems theory) and addressed migration as a negative phenomenon contributing to the further underdevelopment of sending countries (De Haas, 2008). Such arguments were strongly influenced by the core-periphery division, which predicts that migration flow follows the flow of capital in capitalist economies; that is, from peripheral to semi-peripheral then to core nations, all of which ultimately ended up serving the needs of the 'core' countries and isolating the external area comprising poor nations, and creating a migration brain drain (ibid., p.7). Accordingly, migration was believed to have worsened the income and poverty gaps between countries, and gradually increased the dependency of poor countries on capital in core economies (Castles, 2009).

However, from the 1970s, the relationship between migration and development began to be seen in a different light when other alternative theories arose that 
focused on the more positive side of migration (Castles, 2009). This "radical shift" (De Haas, 2008) tends to promote the positive aspects of migration and development, together with a more explicit appreciation of the reciprocity of this relationship, in the sense that a certain level of development triggers migration and migration can contribute to development in both sending and receiving destinations (Piper, 2008). During this period, approach to migration readjusted itself to more subtle views under the influence of empirical work, such as the new economics of labour migration, migration and livelihoods and transnational theories (De Haas, 2008) which re-theorised the links between human action (individual or in groups) and broader processes of change in social structures to offer more comprehensive understanding of the process of migration (Castles, 2009).

Another way to look at the relationship between migration and development is through the study of diaspora. Sinatti and Horst (2015) recently discussed the increased focus on the role of diasporas as the "new agents in development" since the first decade of the new millennium. Migration, once considered as a threat to national identity, social cohesion and security (Castles, 2009; Munck, 2008), now begins to receive much appreciation from scholars and policy makers as the new actor of development in states of origin. According to Sinatti and Horst (2015), this was the time when debates on mainstream development and aid effectiveness arose and the world was looking for new actors in development. In 2003, the World Bank drew attention to the potential impacts of migration when its global financial report showed that the remittances migrants sent home outweighed official development assistance (ODA) (Raghuram, 2009: 104 cited in Sinatti \& Horst, 2015). In 2010, it was estimated that more than $\$ 400$ billion was sent as remittances to developing countries, a figure more than double that of the total ODA (Agunias \& Newland, 2012).

In recognition of this strong linkage between migration and development many states have reformed their economic strategies (Østergaard-Nielsen, 2003, p. 128) to facilitate remittance flows (Barry, 2006; Délano \& Gamlen, 2014; 
Østergaard-Nielsen, 2003), or grant "external citizenship" 3 to diasporas (Barry, 2006; Gamlen 2008, 2014) to welcome investment back to origin states. The United Nations agencies, the International Organization for Migration (IOM), World Bank, the Organization for Economic Co-operation and Development (OECD) and the International Monetary Fund (IMF) have also directed policymakers to the role that diasporas and remittances play in the development of origin states (Weinar, 2010). All these efforts can be viewed as the response to the growing belief that remittances are a more effective instrument for income redistribution, poverty reduction and economic growth than large, bureaucratic development programmes or development aid (Kapur, 2003 cited in De Haas, 2008). After decades of pessimism and concerns about brain drain, governments of migrant sending countries have begun to embrace their emigrants and place new hopes on their 'diasporas' as potential investors and actors of development (De Haas \& Plug 2006; Gamlen 2006 cited in De Haas, 2008).

Migration is a multifaceted and complex process. Studies of migration over the past few decades have been considered by various authors as "diverse and interdisciplinary" (Munck, 2008), "fragmented and narrow" (Castles, 2009), "separated and different in levels of analysis" (De Haas, 2008) and built not on shared concepts and questions (Castles, 2009). The reason for that is because migration (or human movement in general) is dynamic, complex (Munck, 2008) and very contextual. The diversity and complexity of migration as well as the difficulty of separating the phenomenon from other socio-economic and political processes made it impossible to generalize about the causes and consequences of migration (De Haas, 2008). De Haas (2008) therefore called for the need to study migration in its wider societal context and to consider migration not only as an essential process of the much broader transformation processes embodied in the term "development", but also as a dynamic process itself that functions with its

\footnotetext{
${ }^{3}$ External citizenship is the ongoing relationship between emigration states and their citizens who have moved temporarily or permanently to immigration states. It involves emigrants' and emigration states' efforts to preserve links to one another. External citizenship also encompasses emigrants' efforts to remain a part of the societies they left behind, independent of the state, that is, their ongoing engagement with the national community not limited to the national polity (Barry, 2006, p. 6).
} 
own internal, self-sustaining underlying forces that affect such transformation in its own right (De Haas, 2008). Migration cannot be viewed as an independent variable to explain change (in relation to development), but is an integral part of change itself in the same degree that it may enable further change. Therefore, it would be more correct to bring together theories to study the reciprocal relationship between migration and broader development processes instead of looking at it as a one way migration impact on development (ibid., p. 43). Migration is a process which affects every dimension of social existence (Castles \& Miller, 2009), and, as remarked by Castles (2009, p. 1), migration and development are "part of the same process and thus are constantly interactive".

\subsection{Theoretical framework}

\subsubsection{Maximizing income - from individualism to the household decision} Globalization and the liberalization of economies, privatization and the deregulation of the labour market have increased the mobility of capital, labour, goods and services around the world (Beazley \& Desai cited in Desai \& Potter, 2013, p. 411). Neo-classical theory, which was foundational in the 1950s and 1960s for the understanding of labour migration, constructs labour mobility as "the individual decision to migrate, based on the rational comparison of the relative cost and benefits of remaining at home or moving" (Castles \& Miller, 2009). In a sense, neo-classical theory treats the migratory decision as an investment made by individuals in order to maximize income upon weighing their options. The neo-classical model was primarily an economic theory (Castles \& Miller, 2009), and it dominated much of the development thinking during the two or three decades after the end of the Second World War (Binns, 2013).

From the perspective of neo-classical theory, at a macro-level, people tend to move from densely to sparsely populated areas, or from low- to high-income areas (Castles \& Miller, 2009) in response to the structural differences in the supply of and demand for labour (Massey, Arango, Hugo, \& Taylor, 1993). The neo-classical theory perceives migration as the rational human reaction to geographical wage differentials (Hicks, 1932; Greenwood, 1975, 1985; Massey, 1990 cited in Boyle, Halfacree, \& Robinson, 1998, p. 61), which were created by 
the uneven economic development within regions and nations (Pedraza, 1991; Yamanaka \& Piper, 2005).

In brief, the neo-classical model explains a range of reasons for labour migration under the forces of push and pull factors. Among "push-supply" factors that impel people to move, prominent factors are demographic growth, low living standards, lack of economic opportunities and political repression, while "demand-pull" factors such as the need for labour, availability of land, good economic opportunities and political freedom in receiving destinations tend to attract migrants to certain places (Castles \& Miller, 2009). At the micro-level, migrants are portrayed as having perfect knowledge of wage levels and employment opportunities in destination areas and making migration decisions based on these economic factors (Castles \& Miller, 2009) to maximize their aggregate economic welfare (Marshall, 1890 cited in Desai \& Potter, 2013, p. 101).

Neo-classical theorists believed that the flow of labour from low waged markets to high waged markets would lead to factor price equalization. When the free movement of labour leads to a scarcity of labour in the sending areas, in combination with a higher labour productivity, wage levels will increase in migrant sending countries and gradually equalize wage levels across countries of sending and receiving. According to neo-classical theory, the phenomenon of factor price equalization will lead towards an equilibrium of wage levels when no more migration is necessary (Castles, 2009; De Haas, 2008).

Even though neo-classical theory has had much influence in economic studies of migration, it has often been criticized for its individualistic notions and the omission of historical perspectives and contexts (Castles \& Miller, 2009). The application of such an economic push-pull approach - with its main focus on expected income - to the understanding of labour migration have failed to address actual patterns of migration (De Haas, 2008). Neo-classical theory tends to disregard other migratory motives outside of the "utility maximizing individuals" as well as migrants' belonging to social groups (De Haas, 2010). In addition, neo-classical theory depicts migrants as the absolute winners of the migration process and important actors of development when it postulates that they not only bring back money but also new ideas, knowledge, technology and 
entrepreneurial attitudes to contribute to economic growth and development in the sending countries. De Haas has found, in various empirical work, that it is not always the case that migration delivers positive impacts. In some cases, migration has a positive effect on the different dimensions of social and economic development, in other cases it seems to have no effect or even negative effects (De Haas, 2010, p. 240). On one hand, neo-classical theory does not take into account the constraining factors of structural development, market imperfections or government restrictions that can affect the migratory process, thus it appears to be unrealistic to treat migrants as market-players who have full access to information on their options and the freedom to make rational choices regardless of those constraints (Castles \& Miller, 2009; De Haas, 2008). On the other hand, it completely ignores the significance of social, cultural, political and institutional factors (De Haas, 2008), and historical experiences as well as family and community dynamics that are influential in shaping migratory decisions (Castles \& Miller, 2009).

In response to the short-comings of neo-classical theory, the New Economics of Labour Migration theory (NELM) is viewed as a more empirical approach within the same neo-classical paradigm (Abreu, 2012; Castles, 2009). Unlike the neoclassical theory of migration that focuses on the individual income maximization and the rationality of migrants, NELM integrates motives other than individual income maximization in the decision-making process and the risk-sharing behaviour of households (De Haas, 2007; Massey et al., 1993). It shifts the focus of migration from individual independence to mutual interdependence as a household "calculated strategy" (Stark \& Bloom, 1985). Emerging in the 1980s, NELM maintains the focus on income maximization (Castles, 2009) and the rationality of the migrants (McDowell \& De Haan, 1997), but strongly opposes the individualism of the neo-classical approach. According to NELM, families, households, and even communities contribute to migration decisions. Migration is viewed as a "calculated strategy" (Stark \& Bloom, 1985) to diversify the allocation of household income sources to control the risks to family economic well-being (Massey et al., 1993) and provide resources for investment in existing activities in the home areas (Castles \& Miller, 2009). Moving away from the individualistic rational migrants of neo-classical theory, the focus of migration in 
relation to development was shifted onto families or households as the unit of analysis.

\subsubsection{Integrating NELM with the sustainable livelihood approach to understand migration as a household calculated livelihood strategy}

NELM is an economic approach that explains migration as a household strategy to diversify income sources, minimize income risks and ensure security for the family in order to overcome market failures that constrain local production (Taylor, 2004). From the NELM perspective, households sent members abroad to earn remittances for income diversification and the expansion of household economic activity (Gamlen, Murray, \& Overton, 2016). NELM focuses on the households as the "decision-making unit" (Taylor, 1999) and it also "places migration within a broader community context by linking a household's migration decision to its position in the local income distribution" (Massey et al., 1993, p. 458). Specifically, NELM's theory of "relative deprivation" predicts that migration is more likely to happen when there is a difference and comparison in incomes among members of social groups (ibid.). Migrants under the lens of NELM theory are believed to interact within their social groups of family members, relatives and acquaintances in their community and engage regularly in interpersonal income comparisons; and as a result, develop their feelings of relative deprivation (Stark \& Bloom, 1985) that help to shape their migratory decisions. For Stark and Bloom (1985), the greater the gap of income inequality among reference groups of relatives, acquaintances and friends in the community, the more likely for people to feel relatively deprived and therefore have a higher tendency to migrate.

Stark and Bloom (1985) highlighted two factors - risk-handling and coinsurance - as significant for the maximization of the family income through migration. Accordingly, remittances are considered as an additional stream of income to help the family reduce income risk and maximize income insurance to sustain their living. In less developing or developing economies, where there is an absence or imperfection of accessible public or affordable private insurance and credit networks, the risks from market failures can lead to insufficient income and create strong pressures for international movement (Stark \& Bloom, 1985). As a result, families can send one or more members abroad to work and remit 
earnings home when there is no insurance for market failures to guarantee the economic well-being of the family. Migration is considered a mechanism for households to self-insure against income risks to maintain a reliable source of income to support the family; it also helps increase the family income relative to other families in the reference group to reduce their relative deprivation (Massey et al., 1993).

In addition to NELM, this research also utilises the sustainable livelihood approach (SLA) in order to study the complexity of the irregular labour migration process. The definition of "sustainable livelihoods" was introduced in 1992 by Chambers and Conway (1992) in a paper for the Institute of Development Studies (IDS) and later adapted by Scoones and other authors as the following:

"A livelihood comprises the capabilities, assets (including both material and social resources) and activities for a means of living. A livelihood is sustainable when it can cope with and recover from stresses and shocks, maintain or enhance its capabilities and assets, while not undermining the natural resource base" (Scoones, 2009).

The idea of sustainable livelihoods was the starting point for the development of the "sustainable livelihood approach" (SLA) and it was incorporated into development practice (Scoones, 2009) as both "a framework that helps in understanding the complexities of poverty" and "a set of principles to guide action to address and overcome poverty" (the International Fund for Agricultural Development (IFAD) cited in Morse \& McNamara, 2013, p. 10). Rural livelihoods diversification is a "process by which rural households construct an increasingly diverse portfolio of activities and assets in order to survive and to improve their standard of living" (Ellis, 2000 cited in Elliott, 2013, p. 202).

To start with, the livelihood approach offers an analytical framework to study the concept of "sustainable rural livelihoods" and the relations between poverty reduction, rural development and environmental management (Scoones, 1998). In a specific manner, the SLA framework provides a concept for analysing rural livelihood as follows: Given a certain context, condition and trend (of policy setting, politics, history, socio-economic matters), what combination of livelihood 
resources (different types of 'capital': natural, financial, human, social, and others) result in the ability to follow what combination of livelihood strategies (agriculture intensification, livelihood diversification and migration) with what outcomes? (Scoones, 1998, p. 3). Mediating the ability to carry out the livelihood strategies and to achieve (or not) the livelihood outcomes are the institutional and organizational processes that influence access to livelihood resources and the composition of livelihood strategies (ibid.). The SLA framework is often set out as a diagram as shown in Figure 1.

Figure 1: The sustainable livelihood framework

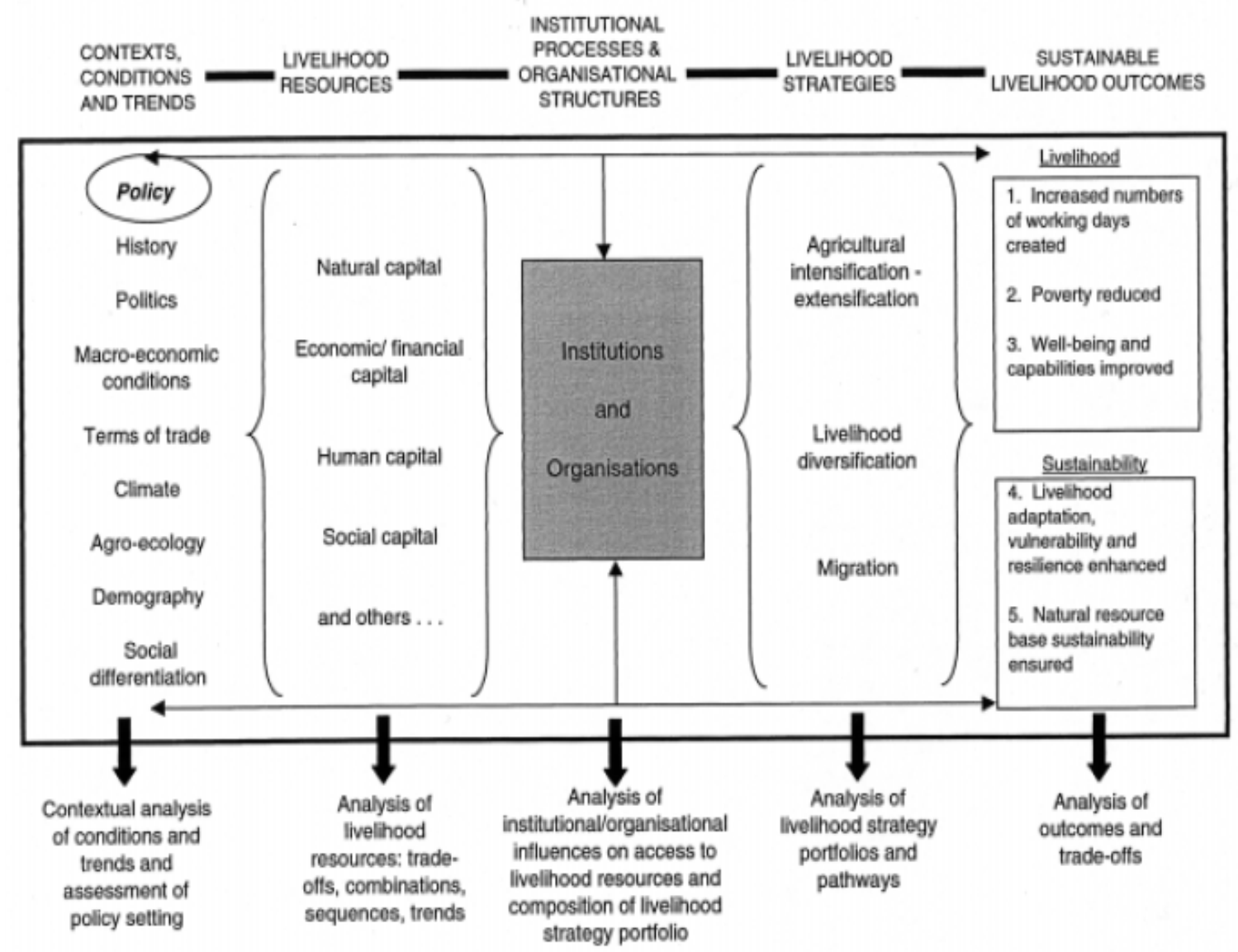

Source: (DFID, 1999).

According to the sustainable livelihood approach, migration is considered one key livelihood strategy among others such as agriculture intensification and livelihood diversification, all of which are crucial in order for rural people to achieve certain outcomes to sustain their livelihoods and cope with livelihood shocks or stresses (Scoones, 1998). 
SLA holds that the ability to pursue different livelihood strategies is dependent on the basic material and social tangible and intangible assets that people possess, referred to as 'types of capital'. A key step in the analysis process is to identify what types of livelihood capitals are required for different livelihood strategy combinations. This often varies between different contexts, thus, understanding how different resources are sequenced and combined in the pursuit of different livelihood strategies (including migration) is critical (ibid.).

There are obvious differences between NELM and SLA framework. NELM is an economic theory predicting the motives of migration and pattern of remittance use while SLA was developed to unpack the complexity of rural poverty through a combination of livelihood assets that result in the adoption of certain livelihood strategies and their relation to rural development. However, both NELM and SLA share the premise of looking at migration "as part of a broader household livelihood strategy to diversify income sources and overcome social, economic and institutional development constraints in the place of origin" (De Haas, 2007, p. 6).

Translating SLA into research can result in a range of topics and research scales because SLA allows researchers the ability to adopt the framework and adapt the analytical scale to their specific needs. In this study I only use one part of the SLA framework. I do not study the sources of capital that the local people of Ha Tinh utilize for their livelihood strategies. Rather, I focus on the concept of "migration as a livelihood strategy" in the SLA and set out to study how the process of irregular labour migration in the context of rural Ha Tinh affects their sources of capital and, at the other end, what kind of development impacts or outcomes it produces for the labour migrants, their families and communities. The combination of NELM and SLA, under their shared premise of viewing migration as a household calculated strategy to sustain rural livelihoods, will provide this research with a theoretical and analytical platform to study the case of irregular labour migration from Ha Tinh in a broader developmental context.

The sustainable livelihood approach highlights and aims to address the multiple linkages between development and poverty. However, connecting migration with sustainable livelihoods to understand migratory determinants does not draw any 
firm conclusions on the causal relation between migration and poverty. While livelihoods and poverty obviously affect, and are affected by migration, there are no easy generalizations in the matter, given the correlation is likely to be contextdependent (McDowell \& De Haan, 1997).

\subsection{Irregular migration in the global context}

In the global migration context, the extensiveness of irregular migration (undocumented or illegal) around the world has probably never been greater than it is today (Castles \& Miller, 2009, p. 3). In Asia, the majority of irregular migration has been treated as a threat to receiving countries in terms of state security and human security (Koser, 2009); it is viewed as a contentious development issue that has been neglected by governments of both sending and receiving countries (Castles \& Miller, 2009). Munck (2008) also finds that one of the debates on the interactions between migration and development views migration as a threat to social security. In his view, the social constructions of migration as the movement of people from different parts and cultures of the world where there may be violence or suppression can give rise to the fear, rejection and uncertainty of unfamiliarity for people in places of destination (Munck, 2008).

Migration management is often tied within the geographic or territorial boundaries of nations and falls in the grey zone between domestic politics and international affairs (Gamlen, 2014). Once a person leaves their home country, their original government is not bound to control and manage their migration since they have moved to a new receiving territory. The same goes for the receiving countries: they have the choice to not control the foreign migrants. By doing so, receiving economies can be benefited from the inflow of undocumented cheap labour workers. The undocumented migrants can find ways to obtain employment and gain a source of income in destination countries. Additionally, there is the "contradiction between state and market" (Castles et al., 2012) where state migration regulations often signal in-migration to be limited, while the market, on the other hand, signals that migrants are welcome by providing employment opportunities to irregular, undocumented migrants. The grey zone of labour management and the need for cheap labour could explain the reluctance 
of governments from both ends of the migratory process in dealing with migration and irregular migration in particular. Baldwin-Edwards (2008) contends that this mismatch between migration policies and the need for flexible labour in the market, has created the conditions for illegal migration and illegal employment (Baldwin-Edwards, 2008). Irregular migration can effectively meet labour needs, but it also creates a situation of insecurity and rightlessness for workers due to the undocumented nature of their migration that can be exploited in an environment where the unwillingness of governments to manage migration coincide with the desire to use cheap and exploitable workers by employers (Castles \& Miller, 2009, p. 135).

\subsection{Migration and Development in Vietnam}

\subsubsection{Vietnamese regular labour migration}

In 2011, it was reported that the law of economic supply and demand on labour force, services, and income, and the differential conditions in living standards between areas, have significantly stimulated flows of labour mobility from Vietnam to other countries (Vietnam Consular Department, 2011). Dang Nguyen Anh, a prominent Vietnamese migration scholar demonstrated that unemployment, labour surplus and lack of economic prospects have contributed in pushing the flow of Vietnamese migration into other destinations where differential wages exist (Dang, 2008). Vietnam's post-war economic development efforts in the 1980s put the country in a modest position behind other nations in the global map of economic development. While regional countries such as Japan, South Korea, Taiwan, Indonesia, Malaysia and Thailand have achieved rapid and sustainable economic growth over a long period of time, Vietnam stands as a newly industrializing economy (Dang, 2008).

Since the beginning of its economic reform, Vietnam has placed a major focus on labour migration as a policy mechanism to increase employment and reduce poverty (ILO Vietnam, 2015). Putting forward a close linkage between migration and development has been key in Vietnam's policy agenda. The Vietnamese Government considered the sending of Vietnamese labour abroad as a relevant policy action in line with current international migration trends (Vietnam Consular Department, 2011). According to the Vietnamese Consular Department 
report in 2011, labour migration also contributes to the improvement of citizen's living conditions, social stability, and work force and labour skills (ibid.)

Vietnam's labour export policy started in the 1980s and was identified by three main waves: the first two were directly to Eastern Europe and the Soviet bloc, partly as a post-war debt-paying mechanism by the Vietnamese government to those countries, and the third wave was into East Asia as part of Vietnam's integration efforts with the regional economy (Dang, 2008). During the 1980s, labour cooperation agreements were signed between the Vietnamese government and the former Soviet bloc to set the quota for dispatch, areas of work, wage levels and so on (Dang, 2008). Since the 1990s, Vietnamese labour export has been subject to licensing (Dang, 2008) so state-owned and private recruitment enterprises have been granted legal licenses from the government to practise their labour sending business. Labour export agencies, as regulated by the Vietnamese Ministry of Labour, Invalids and Social Affairs (MOLISA), are responsible for monitoring overseas markets, securing service contracts, and recruiting, training and sending workers (Dang, 2008). There is a service fee and a large deposit that workers have to pay to the labour export agencies to guarantee their fulfilment of the labour contract (Dang, 2008). The sending of Vietnamese labourers to foreign labour markets through licensed labour export channels became an increasing trend after 2000 when Vietnamese labour migrated mainly to countries like Japan, Korea and Taiwan, Malaysia and other regions like Europe, Eastern Europe, North Africa and the Middle East (Dang, 2008). Labour migration from Vietnam is expected to continue to grow as trade links between Vietnam and other countries in East and Southeast Asia begin to fully develop (ibid.). The Department of Overseas Labour, Ministry of Invalids and Social Affairs reported a number of 500,000 Vietnamese labourers currently working overseas, of which 106,000 moved in 2014 (ILO Vietnam, 2015).

The official labour export programme is believed to ease unemployment in Vietnam, providing local people with a way to diversify their livelihood strategy while the remittances are believed to make a significant contribution to economic growth and social change both at the national level and in localised places of origin (Dang, Tacoli, \& Hoang, 2003, p. 16). However, labour migration also 
entails many issues for Vietnam. Dang (2002) for example, found that outmigration resulted in brain drain. The country lost talent and human resources through educational migration and, in addition, domestically-trained technical emigrants leave the country with their knowledge, talents and skills (Dang, 2002 cited in Dang et al., 2003, p. 16).

Other issues include cases of unfair treatment or labour exploitation. In another example, Belanger, et al. (2011) found that Vietnamese labour migrants in Japan were opting for irregular working conditions and status because they could earn more income by working illegally (Bélanger et al., 2011). In addition to low salaries, those legal workers had experienced an oppressive working environment that forced them to "move out", or "run-away" from the official employer and opt for irregular employers in Japanese markets (Bélanger et al., 2011).

Besides the wish to earn better income through their irregular work, potential migrants understand through networks of former migrants that the capitalist economy is dependent on illegal labour, and that illegal migration is the "normal" way to earn a better life and employment in the world's richest countries (Baldwin-Edwards, 2008). It is also very unlikely for the unskilled or semi-skilled to migrate legally (Baldwin-Edwards, 2008). In sum, even though irregular migration is risky, there is evidence for the factors that condition irregular migration to take place. In response to those factors, more unskilled and lowskilled labourers are seeing that irregular migration can be adopted as their livelihood strategy. Additionally, Belanger et al. (2011) also pointed out that the precariousness of the migratory process can bring about certain advantages to migrants, rather than being official, contract-bound and documented (Goldring et al., 2009 cited in Bélanger et al., 2011).

\subsubsection{Gender and migration in Vietnam}

This section presents a discussion of traditional Vietnamese gender characteristics which is necessary to allow a further discussion on the interaction of labour mobility and gender relations in the construct of rural livelihoods. 
Werner (2002), has pointed out the complexity of contemporary gender relations in Vietnam, arguing that they are "a compound of norms, values and practices inherited from a distant 'Confucian' past as well as a more recent 'socialist' one, together with changes associated with the current period of transition to the market economy and integration into the global economy" (Werner, 2002).

Owing to the Confucian heritage, traditional Vietnamese society is patriarchal; boys receive more attention in the household than girls because they would be the ones who continue their father's patrilineage (Drummond \& Rydstrøm, 2004). A son's special position stimulates more freedom of action for men, while women have been taught to be more reserved in their behaviour. The idea of "good morality" has been taught from generation to generation of Vietnamese women to embrace controlled behaviour, to nurture a good reputation for the family, and to make up for the fact that they could not carry on their father's patrilineage (cf. Long 2000; Nguyen Tu Chi 1991; Pham Van Bich 1998; Rydstrom 2003a cited in Drummond \& Rydstrøm, 2004, p. 91).

The four Confucian feminine virtues (tu duc) of "cong" (labour), "dung" (appearance), "ngon" (speech) and "hanh" (morality), have a strong influence on how Vietnamese women are brought up and how they should present themselves in the society, though the focus has become less extreme in the modern days. Generally speaking, Vietnamese women are expected to be gentle, proper and feminine (Ngo B., cited in Drummond \& Rydstrøm, 2004, p. 47). Bearing in mind another teaching from Confucianism about family hierarchy, traditional Vietnamese women are supposed to listen to their father in the household, listen to their husband when they are married, and later in life let their son decide their situation. The social construction of femininity in Vietnam concentrates evidently on fostering female characters to be feminine and obedient, with an overarching attention paid to their symbolic functions of reproducing and care-taking.

With this in mind, the gendered beliefs in Vietnamese society have a strong influence on people's perceptions of rights, obligations and legitimate behaviour in relation to other people, as well as the way their migration is strategized within the household (Hoang, 2011). According to Hoang (2011), women's agency around their own migration was in part constrained because they were forced to 
negotiate for their interests whilst trying to preserve family harmony. Hoang (2011) also identified in her research four Vietnamese female migration patterns: consensual, uncontested, negotiated and conflictual. Consensual migration is when the decision is made upon mutual consensus within the household prior to migration. Uncontested migration are cases where migrants made the decision themselves without consultation with other family members, and negotiated cases are migrants who were able to negotiate and persuade their families to agree for them to migrate, given their initial disagreement. Conflictual migration involve cases where there is no consensus within the household on the decision to migrate.

Family ties and patriarchy are important factors in Vietnamese households and so most migratory decisions preferably need the consensus of the family, with the most important power in the hands of the male head of the house. Gender norms and gendered labour divisions in households have been found to be key determinants of migration behaviour (Chant 1991, Lawson 1998 and Hampshire 2002 cited in Hoang, 2011). It used to be rare for Vietnamese women to migrate, since their roles are assumed to be associated with the care-taking of their family members and children. The fact that a woman in the household has to migrate also indicates a social belief that her husband is unable to take care of the family. Cases of married female migration have the tendency to damage the reputation of husbands: either their masculinity will be contested by social expectations, or they would feel shameful in comparison with other men in the community for not living up to the gendered division of labour and having to take over the wives' care-taking roles. At the same time, the migrated wives also attract rumour and social judgment for not being "good wives" (ibid.).

Additionally, motherhood is considered a crucial component for a woman's identity in Vietnamese society (Rydstrom, cited in Drummond \& Rydstrøm, 2004, p. 75). Women are judged by their reproductive roles and female migrants often have to endure the belief that they have chosen to focus more on economic benefits by migrating while leaving their children behind with their fathers. Women themselves feel the threat of low self-esteem when not being able to take proper care of their children. 


\subsection{Summary}

This chapter has engaged with the relevant literature surrounding migration and development from the global context to the Vietnamese context. From the global perspective, I have reviewed the relationship between migration and development through different periods of time and change of viewpoints. In the following section, I presented the theory and approach that provided me with the foundational understanding of the subject of irregular labour migration that this research is concerned with. The combination of the New Economics of Labour Migration theory and the sustainable livelihood approach as the theoretical and analytical framework that guides my research makes clear their shared premise that migration may be viewed as a household calculated strategy to sustain rural livelihoods. Through this, my research seeks to examine the case of Vietnamese irregular economic labour migration and locate its relationship with development, exploring whether irregular labour migration is a strategy to sustain rural livelihoods. To better foreground this aim of the research, the two sections following the theoretical framework section provided a brief review of irregular migration in the global context and then moved on to discuss the relationship between migration and development in the context of Vietnam. Specifically, the discussion on migration and development in Vietnam demonstrated that the regular labour export programme regulated by the Vietnamese government has both positive and negative effects. While regular labour migration can be a strategy to sustain livelihoods for many Vietnamese workers, its regulated fees were considered high, and the regular working experience in some cases was found to be low-paid and exploitative. The negative experience in combination with the loose migration management policy in destination countries has paved the way for irregular migration to emerge. In respect of migration and development in Vietnam, I also presented the characteristics of Vietnamese gender in relation to migration; this section provided a background for my discussion in Chapter Six in regards to gender relations.

The quest of this research is to examine whether irregular labour migration can be a strategy to diversify and sustain rural livelihoods. All the relevant literature discussed in this chapter will be referred to throughout the thesis to highlight the 
impacts of a complex issue of Vietnamese irregular economic labour migration, and offer deeper understandings of how and why people engaged with such migration to sustain rural livelihoods from a local perspective. 
This page is intentionally left blank 


\section{Chapter 3: Methodology}

\subsection{Introduction}

This chapter presents the methodology that informs the conduct of the research. Firstly, it introduces the epistemology that guides the action of the research. It then moves on to discuss the researcher's positionality in the field. Thirdly, it explains in detail the qualitative design of the research and its case study approach. In this section, I discuss the access to the field site, and the sampling and recruitment of my research participants. The chapter continues with a section on the process of data collection and analysis. The final section reflects on the ethical considerations of the research.

\subsection{Research Epistemology}

Epistemology is the way of understanding and explaining how knowledge is acquired (Crotty, 1998), thus it is necessary to discuss it within the research (Creswell, 2009). Epistemology provides a philosophical grounding (the logic and criteria) for deciding what kinds of knowledge are both adequate and legitimate (ibid.). In short, epistemology is "a basic set of beliefs that guide action" (Guba, 1990 cited in Creswell, 2014, p. 6) for the research. There is a range of epistemologies, and each approach implies a profound difference in how research is conducted and the outcomes it presents (Crotty, 1998). This research is informed by social constructivism, which holds that truth and meanings are created by individuals' interaction with the world (Gray, 2004). Specifically, individuals develop subjective meanings of their experiences. Often these subjective meanings are negotiated socially and historically through interaction with others (hence socially constructed) and through historical and cultural norms that operate in individuals' lives (Creswell, 2003, p. 9). In this research, my aim is to study and understand my research participants' historical and social perspectives and later interpret what I find to generate meaning from the data collected (Crotty, 1998 cited in Creswell, 2009). As a qualitative study informed 
by constructionism, this research looks at (1) how people interpret their experiences, (2) how they construct their worlds, and (3) what meaning they attribute to their experiences (Merriam, 2009) in their social, historical and cultural settings (Creswell, 2003).

\subsection{Researcher's Positionality}

Positionality frames social and professional relationships in the field (Chacko, 2004). A researcher often assumes the status of an insider and/or an outsider during their fieldwork. This affects how their participants perceive and interact with them in the field and, therefore, influences both the data collected (Sultana, 2007) and the information that becomes coded as "knowledge" (Clare Madge, 1993: 296 cited in Rose, 1997). Positionality sets the tone of the research and affects its course and outcomes (Chacko, 2004). Being critical and reflexive about one's positionality is to reflect on how one is inserted in grids of power relations, and how that influences methods, interpretations and knowledge production (Kobayashi, 2003 cited in Sultana, 2007). When it comes to the matter of exploring the multidimensional geography of power (Rose, 1997) in its relation to knowledge production in doing research, "positioning is ... the key practice grounding knowledge" (Haraway, 1991: 193 cited in Rose, 1997). The knowledge produced during fieldwork research is partial, contextual, social, political and institutional, so researchers need to recognize the differences in power, knowledge, and truth claims. Further, they must constantly negotiate these factors to have more meaningful and respectful ethical research (Sultana, 2007).

Many feminist researchers in their work have written about their privileges in relation to their research participants. In my view this is the way for researchers to acknowledge their positions and the power they assume as the controllers of the research. Those privileges vary, from educational backgrounds and professional statuses (Kobayashi, 1994 cited in Rose, 1997), to material inequalities, differences of opportunities, and the power of interpretation exercised in the final result (Gilbert, 1994).

My research was conducted in Ha Tinh, a rural province in the Central Coast of Vietnam. Ha Tinh was chosen for this research after a survey by ILO Vietnam 
reported that a significant number of local people had migrated irregularly from the province (ILO Vietnam, 2015). I was firstly intrigued by the matter of irregular labour migration, and wanted to investigate more specifically the process of migration and how that had an impact on the people and community. Secondly, because Ha Tinh is my mother's hometown, I felt closely related with the province and decided to conduct my research here as the way to reconnect with my roots. Conducting fieldwork in Ha Tinh also gave me a chance to apply my new knowledge gained through my course of Development Studies and contribute to the better understanding of a new development issue that emerged from the land that I feel dearly connected to.

Returning home to Vietnam for my fieldwork placed me as both an insider and an outsider (and of course, one with privileges given I am a city girl and was living overseas in New Zealand for my study). The rural environment and level of economic development in the field site were quite different from the capital city of Hanoi where I was born and have lived most of my life. I had been away for almost a year and a half in New Zealand, and upon returning home for my field work, even my city was becoming the new 'old environment' that I had to adjust myself to. In addition, the tropical summer heat in Ha Tinh was also more extreme. Ha Tinh, where my research participants reside, is not my 'home', even though I still have strong family ties; not only was my mother born and raised there, but several relatives still live in the province, while childhood memories of summer vacations spent with my grandparents in one of the villages made me feel familiar and connected to my roots and to its rural settings (Sultana, 2007). What made me an insider was my familiarity with historical factors and political processes and the feeling of being 'native' (Sultana, 2007), and my connection with the site through my mother and relatives. I noticed that introducing myself as the daughter of my mother - a former villager in the research site who still has her family ties there - has enabled me to be more quickly accepted by most of my participants. In a small rural community where everyone seems to know each other, people were very welcoming and willing to share their stories and contribute to the study of their fellow villager's daughter. A lot of the participants do not actually know my mother in person, but by associating her with my late grandfather, the participants were able to 'locate' her. Being aware of my insider 
status, I made sure none of my participants were related to our family. The fact that none of my relatives who still live in the villages are irregular migrants also helped me minimize the possible biases or conflict of interest during my interviews with other irregular migrant workers.

Despite the family connection during my time in the field, I felt that my outsider status was more dominant than my insider role, and I was aware of differences between myself and the research participants (Gilbert, 1994; Rose, 1997). Being an urban young professional pursuing a higher education degree overseas, I was aware that my class and educational privilege (Sultana, 2007) might have had an effect on how I was being 'othered' in the rural area. There were material and symbolic differences (ibid.) to be noticed, and I was a total stranger to the villagers. I constantly tried to be mindful of the differences and the power imbalances, be careful with the way I interacted with my research informants and the local people in the villages, and the way I behaved in the community (Scheyvens \& Storey, 2003). To show respect and to avoid the sun, most days I dressed myself in long pants, long sleeved shirt and opted for sports shoes for comfort. I wore a big backpack that carried every possible thing I needed while on the move: a bottle of water, my notebooks and interview papers, my phone as a camera and a recorder, a handkerchief and a paper fan to keep me cool. My backpack was huge and I wore a sports hat that could easily distinguish me from the 'locals', as men in the villages wear military hardhats and women wear the signature Vietnamese conical hats to keep them cool in the sun. Local people in the villages tend to share a similar style of dress: men would wear long dark pants of thick fabrics and light-coloured shirts, while women mostly wear plain coloured pants and floral blouses or shirts. My long sleeved blue flannel that I wore outside my T-shirt as protection from the heat was also different in look to the locals. Everywhere I went, I noticed people looking at me because of my different appearance.

In the rural community where people have come to respect and be deferential to urban, educated elites (Sultana, 2007), I constantly had to negotiate my "sameness" and my "differences" (Rose, 1997). Despite the sameness of ethnicity, nationality, language and the ability to engage in regular conversations (Sultana, 
2007), the participants I talked to in the field seemed to place me in a hierarchy with respect to my education. They treated me with respect and hospitality and were genuinely honest and willing to share. As one of my women participants said: "I will tell you everything I know, this is only for the sake of your study, and I have nothing to hide". I was touched by the honesty she offered, and at the same time her comment drew me to my awareness of my fortunate education. I became even more appreciative knowing that her genuine comment showed the typical appreciation and encouragement for education often expressed by local people towards younger generations. I felt clearly that I had been treated with 'sameness' despite my 'differences'. At that moment, I remembered reminding myself that the work I was doing was not just "for the sake of my study". It was more about their true stories, their views, and it was not just about them, but for them. It was also during my time with the participants that I became more conscious about people's hospitality towards me. In every household I visited, I was offered fresh green tea in a clean glass, and while we were seated on the wooden sofa in their living room or in their yard, the interviewees always brought a fan in themselves, or told their kids to plug in the fan and have it blow the cool air to my side of the table. It did not seem likely to me that each household had enough electrical fans for every room in the house; often the fans are mobile and flexible for when they have guests over. Those were the hottest days of summer. The temperature always felt like 40 degrees Celsius, and the hot and dry westerly wind from Laos to Central Vietnam made it even harder to bear.

During all the interviews I conducted, the different attitude people had towards me as a young female researcher constantly shifted my positionality. The men were neutral in sharing their stories, often quite reserved when asked about their feelings about their experience. In the rural field, to my observations, the men still act like the heads of their households and have a certain power over other family members. The social norms around masculinity often portray them as men of action, not feelings. In this case, my gender identity may partially have influenced the way they expressed their feelings about their migratory experience during our interviews. The older women were more comfortable with me, treating me like a peer of their children. The younger women were more emotional in sharing their feelings of the irregular labour experience, and this made me ponder 
whether or not my education and urban background and privilege may have emerged more vividly as signs of difference between us as women of similar age, especially during the sharing of hardships. Apparently, even though we were women of similar age, our lived experiences were very different. Upon my realization of our sameness and our differences - the challenges they faced working illegally overseas, and my privileges with my life in New Zealand - I tried not to reinforce any feelings (Scheyvens \& Storey, 2003) as they described, emotionally at times, the difficulties they face in destination countries; instead I just listened and told them afterwards that I appreciated their sharing (ibid.). That being said, I realized that the differences in identity between me and the research informants - especially with the group of female migrants who were similar to my age - may have affected the way information was shared with me, even though all participants were very generally open to share their experiences. In sum, being an academic researcher from a foreign education institution working in a rural field has helped me reflect on and become more conscious of power relations and (mis)representations in the field. My insider status seemed to help people to accept me more easily and quickly into their homes, thus interviews were more accessible. My outsider status was more obvious, placing me in different interpersonal relations with my participants. However, my respect for the people and my belief in the research and the representation of their stories made the process of trust-building possible. Even though there were differences, we were able to share affinities (Haraway, 1991 cited in Sultana, 2007) through honesty. I was aware that the different positionalities I assumed in the field required for me to be constantly reflexive, towards both 'others' and myself (Pillow, 2003) in negotiating my 'insider' or 'outsider' status to stay neutral with respect to the truth. I have tried to exercise reflexivity and stay constantly alert to potential power imbalances and any signs of difference that emerged in various interactions and contexts. Being aware that meanings are socially constructed for my research participants through their interaction with others, I have paid more attention to mindfully observe their identities, behaviours and expressions during our interviews. I was also flexible with my flow of questions and spent as much time as I deemed necessary to allow myself to gain a better understanding of my participants' situations, their stories and 
experiences in light of the social and historical contexts in which they lived. It is obvious though that my time spent in the field was very limited, therefore the effort to fully gain a thorough understanding of the socially constructed truth is impossible.

There are issues of truth and deception that also worth noting during the course of research. Accordingly, to what extent people reveal the truth is unknown and uncontrolled at both ends of the interaction. A researcher may tell lies to achieve research objectives; on the other hand, research informants can also tell lies or partial truths in order to influence the research to their advantage. Scheyvens, Nowark and Scheyvens (2003) suggest that it is best that researchers be guided by their conscience, focusing on the best interests of those being researched ( $p$. 161) to navigate research through the issues of truth and deception (Scheyvens \& Storey, 2003, p. 161). With my research, I have been honest with my research participants about my research objectives. From their end, I believe that all the participants to whom I talked have extended their honesty regarding their migration experience.

To sum up, I acknowledge that balancing my positionality and being attentive to the power relations in the field was not easy, especially with the growing attachment I developed with the field towards the end of my fieldtrip. At the end of my time in the field, I had become familiar with the local settings and the routes between and in the villages. I also felt more like a local towards the end of the stay because I felt that local people had also became familiar with my presence. The stories that I was told also made me feel more attached to the land, the people and the stories they shared. Automatically, I felt my responsibility to stay ethical and truthful with the information I gained through the time spent with the research participants due to the sensitivity of the stories. My family ties with relatives, and very strongly with the land itself, was strengthened. However, I have also felt my privilege because I had the option to leave this local reality and move on with my own. I also remembered my joy and satisfaction upon the collection of the data for my research. With this being said, I also realized that it was natural for me to develop all these feelings upon my departure from the field, therefore I allowed myself the space to accept those feelings and acknowledge 
both my negative and positive feelings. During the time in the field, I have attempted to stick with my ethical procedures and thus not engage with the participants at a personal level before, during and after the interviews were completed to allow myself a neutral analysis of the data received. I am aware that the most appropriate way I can thank my participants and pay tribute to them is through conducting an ethical research that focuses on the interests of my research participants, and thereby present the research matter as genuinely as the data reflects (Scheyvens \& Storey, 2003, p. 207).

\subsection{Research Design}

Before fieldwork was conducted, a preliminary literature review about Vietnamese irregular economic migration was compiled to identify the research questions and locate the field site. Fourteen days of fieldwork was carried out in a pre-selected province in Central Vietnam because of the large number of irregular economic migrants in the terms identified by the existing literature. The documents collected during the fieldtrip were reviewed after the interviews to provide additional background data and to help construct the overview of the field site in the context chapter. A list of research methods and tools used during the fieldwork is presented in Table 1 below. 
Table 1: Research methods and tools used during fieldwork

\begin{tabular}{|c|c|c|}
\hline Research method & Participants, data and location & $\begin{array}{l}\text { Research tools/ } \\
\text { activities }\end{array}$ \\
\hline $\begin{array}{l}\text { Semi-structured } \\
\text { interview }\end{array}$ & $\begin{array}{l}20 \text { semi-structured interviews in } 4 \\
\text { villages in the field with } 4 \text { groups } \\
\text { of informants: } \\
\text { - } \quad \text { Irregular economic migrant } \\
\text { workers } \\
\text { - } \quad \text { Family members of irregular } \\
\text { economic migrant workers } \\
\text { - Official of Provincial } \\
\text { Department of Labour, Invalids } \\
\text { and Social Affairs (DOLISA) } \\
\text { - Local leader }\end{array}$ & $\begin{array}{ll}- & \text { Pre-designed } \\
\text { interview questions } \\
\text { for each group } \\
- & \text { Field notes } \\
- & \text { Interview recordings }\end{array}$ \\
\hline Informal interview & $\begin{array}{l}\text { Informal discussion were } \\
\text { conducted with a staff member of } \\
\text { the International Labour Office } \\
\text { (ILO) in Hanoi, and with two other } \\
\text { irregular migrant workers from } \\
\text { two different provinces of Vietnam }\end{array}$ & $\begin{array}{ll}- & \text { Field notes } \\
- & \text { Recordings }\end{array}$ \\
\hline Observation & $\begin{array}{l}\text { - Livelihood observations of the } \\
\text { migrant workers' households } \\
\text { during interviews } \\
\text { Community observation of the } \\
\text { area while moving between } \\
\text { and around the villages } \\
\text { Observation of local people at } \\
\text { the village cultural houses and } \\
\text { at local coffee shops }\end{array}$ & $\begin{array}{ll}- & \text { Field notes } \\
- & \text { Photography }\end{array}$ \\
\hline $\begin{array}{l}\text { Secondary data } \\
\text { collection and } \\
\text { visual materials }\end{array}$ & 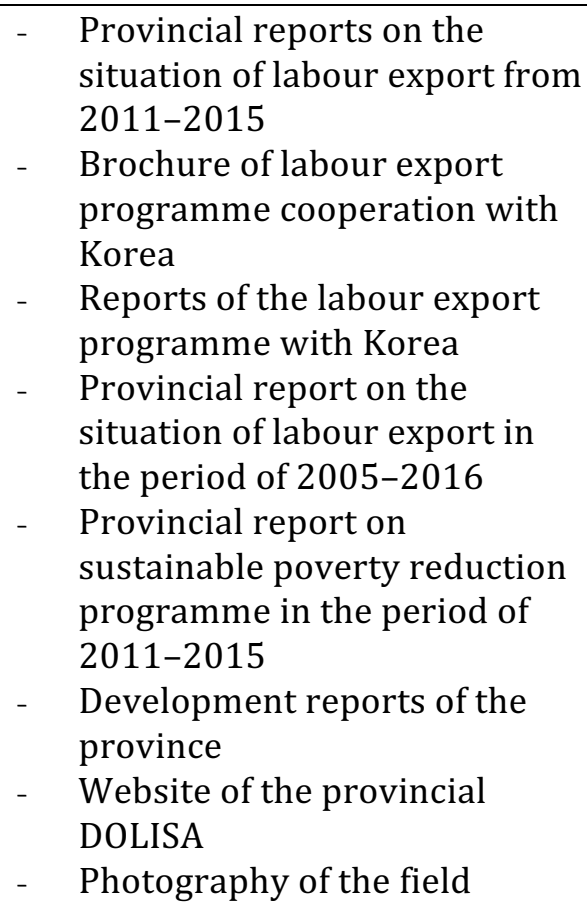 & $\begin{array}{l}\text { Soft copies of the } \\
\text { reports were } \\
\text { obtained through } \\
\text { communication with } \\
\text { DOLISA staff } \\
\text { - Copy of the provincial } \\
\text { report on the poverty } \\
\text { reduction programme } \\
\text { from one of the local } \\
\text { leaders }\end{array}$ \\
\hline
\end{tabular}




\subsection{Qualitative research and case study approach}

Qualitative research can be defined as a tool to describe the human environment, individual experiences and social processes (Hay, 2010, p. 5). In the sphere of my research, that involved discovering individuals' perceptions, feelings and experiences of irregular migration processes and their lived experiences through the lens of qualitative methods. The primary method I have chosen to achieve this is the semi-structured interviews; that is, to study and understand irregular migrant workers' historical and social perspectives through in-depth interviews comprised of open-ended questions (Creswell, 2009). A case study approach was utilized as the main method for this research because it is the most suitable tool to help unpack the situation of Vietnamese irregular migration in depth. A case study is "an intensive study of a single unit for the purpose of understanding a larger class of (similar) units" (Baxter, 2010 cited in Hay, 2010, p. 81). Case studies focus on illuminating a decision or set of decisions: why they were taken, how they were implemented and with what result (Schram, 1971 cited in Yin, 2009 , p. 17). The case study method is most likely suitable for "how" and "why" questions (Yin, 2009), which works well to support my sub-questions in the research.

\subsubsection{Access to Community}

This research was inspired by a 2015 household-survey report from a wellestablished international labour organization in Vietnam. Through a connection with a former colleague, I was able to contact the Vietnamese staff member from the International Labour Organization (ILO) who coordinated the report project. Emails and phone calls were made prior to my trip back to Vietnam in June 2016 to explore with the staff the requirements necessary to conducting my field work and discuss my fieldtrip arrangements. When I arrived in Hanoi, we were able to meet and talk about my research inquiry. Since irregular economic migration from Central Vietnam can be quite a sensitive topic with its negative, illegal connotation, the staff suggested that I acquire formal introduction letters from either the Ministry of Education and Training (MoET) (given I was doing this for my higher education thesis), or the Ministry of Labour, Invalids and Social Affairs (MOLISA) (due to the field of research on labour migration). According to the ILO 
staff, an official introductory letter would help me access the field more easily. In her opinion, an introduction letter of any kind from the Vietnamese authority would ensure me easy access to the community and save me from trouble in case there was any concern about the sensitivity of the research. I spent two weeks in Hanoi trying to arrange such a letter and waiting to hear from my contacts in the Ministries. However I was eventually told that since I don't have any professional working relation with either Ministry, they could not offer an introduction letter with their official stamps. After two weeks of waiting, I decided to go to the field without the introduction letters.

When I got to the first village, one of my relatives took me to see the local leader of the village. I introduced myself to him with my VUW documents and asked for his permission to access his village for interviews. After spending his time examining my documents and the research questions carefully, the leader granted me his permission. He provided me with a document containing the commune's report on the implementation of the sustainable poverty reduction programme on the last day of my fieldtrip, after he had observed my time spent in the field and perhaps noting that I had built some trust. Despite the lack of an official letter from the central organization, the verbal permission by the local leader of the first village was also powerful enough to gain me access to the first village. Since the villages I wanted to go to were not too far from each other, and fortunately the local people seemed to know people from other villages, I had no trouble getting to other villages by using the permission of the local leader in my first village as a guarantee for my visit. Being able to gain access to the villages without affiliation to any central ministerial authority, or ILO Vietnam who conducted the household survey report in the area, has enabled me to (1) be independent in my analysis and bear no influence under any organisation's viewpoint, (2) mitigate any possible conflict of interest, and (3) maintain freedom in framing my research questions in line with my own research direction. The Vietnamese staff from ILO had given me the contact of a provincial governmental official from the provincial Department of Labour, and she had also made contact in advance to introduce me and arrange a meeting when I arrived in the province. It was made clear to me that the information I gained from both of these contacts (from the international organisation and the provincial department) reflected 
their own personal perspectives and not necessarily those of their own organisations.

\subsubsection{Sampling and Participant Selection}

Sampling in qualitative research is not intended to be representative, since the focus is on the analysis of meanings in specific contexts (Robinson, 1998 cited in Hay, 2010, p. 76). In case study in-depth interviews, interviewees can suggest other persons for interview, as well as other sources of evidence. This form of assistance, according to Yin, changes the role of the interviewee from a respondent to an informant (Yin, 2009). Key informants are essential to successful case study research (Yin, 2009). For a small-scale research project, snowball sampling is an effective technique for collecting a reasonable sized sample (Denscombe, 2014). Snowball sampling is the process of selecting a sample using networks (Kumar, 2014). In this process, a participant will be asked to identify other people in their networks, with the people selected for participation as a result becoming a part of the sample (ibid.). By using the snowballing technique, the accumulation of interviewees is quick, using the multiplier effect of one person nominating two or more others (Denscombe, 2014).

In addition to snowball sampling, I employed purposive sampling to ensure a sufficient number of participants was included in the sample. Unlike snowball sampling based on references from one person to the next, purposive sampling targets participants with "the particular qualities" that are relevant to the topic of investigation and likely to produce the most valuable data (Denscombe, 2014, p. 17).

My participants were recruited both through snowballing and through an initial referral from one of my relatives in the village who made some initial enquiries for me, from which I continued with my own participant recruitment. Through him first asking around the village for me, I was able to gain faster access to participants. The main criteria I had for recruitment of participants was to find people who had gone abroad legally and then become irregular workers by overstaying their visa and working without a work permit. Among the 
participants I was able to locate through purposive sampling, many were not known by my relative.

During my time in the field, I was conscious of the influence that the relative may have had on my participant selection and whether this would create any imbalance in the data gathered, therefore I made sure that any participants who were referred to me had no relation to our extended family. Additionally, as none of my relatives who still live in the area were irregular economic migrant workers, this helped me eliminate any possible biases in the data collected. I ensured that my interviews with participants were conducted one-on-one, and that none of the stories shared were discussed with my relatives or anyone in the field. I decided to stay in a hostel instead of with family, which, to them, was disappointing because they genuinely wanted to take good care of me. This, however, has helped me maintain my neutrality and minimize any misunderstandings (if any) of biases from the local people and/or my research participants in the village.

\subsubsection{Recruitment of participants}

Participants of the research were purposively targeted from four different villages in Ha Tinh province to ensure more diversity and breadth of data collected.

Irregular economic migrant workers: As mentioned above, irregular migrant workers were recruited through snowballing and referral from the villagers. The villages were small communities where everybody knew each other, so it was not difficult for the villagers to point me to relevant target participants. Regardless of the recruitment technique, all irregular migrant workers whom I had the chance to talk to in the field were open to sharing their stories and happy to introduce me to similar cases as theirs. More than half my participants were introduced to me through snowballing. All interviews were conducted at their homes in order to create a comfortable atmosphere for the conversations. A majority of the interviews were conducted at noontime when the workers were present at home after their time doing farm work in the morning. This is the only time they could see me due to their commitments to other agricultural tasks in the sowing season. 
Family of irregular economic migrants: In addition to the migrant workers, I was able to talk to four family members of the irregular migrant workers in order to explore the change of roles during the migration as well as the effects migration had on the family members left behind, and their perceptions and views about the migration process. It was the busy sowing time in the field, so most of the family members were away to work or in the paddy fields sowing.

Local leader: One interview was conducted with the local leader who granted me permission to access the villages for interview. Due to the sensitivity of the research topic and his personal confidentiality concerns, the leader agreed to share his perspective with me, however he specifically requested that his identity remain anonymous and for the interview to not be recorded.

Official from provincial Department of Labour, Invalids and Social Affairs: I was introduced to this official by the contact from the Vietnam International Labour Organization (ILO Vietnam) in Hanoi. He was in charge of labour issues in the province and had worked with ILO Vietnam during the household survey in the province. I made contact with the official before I arrived in the field to inform him of my trip, however I chose to interview him at the end of the fieldtrip to validate some of the initial findings I gathered during my time in the villages.

Regular migrant worker: Through the snowballing introduction of one of my informants, I was unexpectedly introduced to a regular migrant worker. The informant directed me to one of her acquaintances who used to work overseas. However, when we were talking, I discovered that she was a regular migrant worker who had migrated to Malaysia through official labour export channels in the province. Interestingly, the interview with the regular migrant worker in the village provided me with some background for comparison between the migratory experiences of a regular and irregular worker from the same area. 
Table 2: Summary of Informant profiles $(\mathrm{N}=20)$

\begin{tabular}{|l|c|c|}
\hline \multicolumn{1}{|c|}{ Category } & Number & Percentage \\
\hline By background & 13 & $65 \%$ \\
- Irregular economic migrant workers & 4 & $20 \%$ \\
- Family member of irregular migrant workers & 1 & $5 \%$ \\
- Local leader & 1 & $5 \%$ \\
- Official from provincial Department of Labour, & 1 & $5 \%$ \\
$\quad$ Invalids and Social Affairs & 11 & $55 \%$ \\
- Regular migrant worker & 9 & $45 \%$ \\
\hline By gender & & \\
\hline$\quad$ Male & & \\
\hline
\end{tabular}

\subsection{Data collection process}

\subsubsection{Pre-departure preparation}

Prior to the fieldwork, my information sheet, consent form, interview guides (See Appendices 1 to 6) were prepared to apply for my human ethics approval. After receiving the approval (See Appendix 7), I flew back to Vietnam for fieldwork. The prepared documents were used as tools to conduct my field research.

\subsubsection{Data collection in the field}

To maintain the credibility of the case study research, triangulation of data sources is essential (Yin, 2009). "The use of multiple methods of collecting data (methods triangulation), for example, can be seen as a strategy for obtaining consistent and dependable data, as well as data that are most congruent with reality as understood by the participants" (Merriam, 2009, p. 222). This research uses semi-structured interviews as the primary data collection method and participant observation as the secondary one. Other tools for data collection to ensure triangulation included field notes, photography and collection of visual materials and other provincial reports acquired from the field.

\subsubsection{Semi-structured in-depth interviews}

This research employed in-depth interviews to ask key respondents about the facts of their irregular economic migratory experience as well as their opinions about the matter. DeMarrais (2004) defines an interview as "a process in which a researcher and a participant engage in a conversation focused on questions related to a research study" (cited in Merriam, 2009, p. 87). The interviews were 
designed to be semi-structured so that the researcher has more freedom in articulating flexibly-worded questions while ensuring the interview is a mix of more or less structured questions (Merriam, 2009). The semi-structured interview allows the researcher to seek specific information from the respondents, and, at the same time, remain flexible, since a large part of the interview is guided by a list of questions or issues to be explored that is neither defined by any exact wording, nor to be set in a structured order ahead of time. This format allows the researcher to respond to the situation at hand, to the emerging worldview of the respondent, and to new ideas on the topic (Merriam, 2009, p. 90). Well-informed interviewees can provide researchers with important insights into the case as well as shortcuts to the prior history of the situation (Yin, 2009, p. 108); however, any interviewees' responses can be subject to common problems of bias, poor recall, and poor or inaccurate articulation. Hence, it is essential that the researcher corroborate interview data with information from other sources (Yin, 2009, p. 109).

During the fieldwork, the semi-structured form of the interviews allowed for flexibility in generating new questions in response to informants' natural flow of viewpoint and recall. I had to note down in my interview guide any new ideas raised by my informants in order to adjust the flow and revise the questions for future interviews.

\subsubsection{Participant observation}

In addition to the in-depth interviews, participant observation was employed as the secondary data collection technique. This method allows the researcher to engage in the events being studied, with activities ranging from casual social interactions with various community residents to undertaking specific functional activities within the neighbourhood (Yin, 2009, p. 111). Observation in the field supports the researcher's generation of data through observing and listening to people in their natural setting, and to discover their social meanings and interpretations of their own activities (Gray, 2004). One of the main concerns for participant observation is that, to be able to observe the participants, the researcher should become "immersed" in the research setting, getting both physically and emotionally close to the participants; this makes it challenging to 
balance between 'insider' and 'outsider' status (ibid.). Furthermore, the act of observation itself may bring about changes in the activity, rendering it somewhat atypical (Merriam, 2009). It is thus critical that the researcher be aware and mindful of the field happenings and practises positionality and reflexivity on a regular basis.

Participant observation was essential for this research. Through observation, I was able to study the participants' household livelihood, their daily life and interactions with their family and neighbours. The social and contextual background of the research participants plays an important role in their construction of meanings of their lived experience. I also took note of the local surroundings to examine the socio-cultural infrastructure of the area. Observation of the interaction among family members enabled me to have some understanding of the gender relations and hierarchy in the traditional households. During the interview, I also noted down in my notebook the reaction of my participants during our conversation, and the happenings around the interview space.

Participant observation was helpful for me to study the cultural context of the field, adjust my research questions where necessary, and deepen my understanding and interpreting of the background around the research participants' household livelihood. For ethical issues, I have restrained myself from getting personally connected with my research informants. However, I placed much focus on learning about the rural surroundings, the culture and livelihood settings when possible. In one circumstance, I was invited to have lunch with a local family in the village on a day when no interviews were scheduled. Even though the family was not one of my research participants, I took the chance of attending the meal to observe their daily life. I thought it was important for me to learn about the culture and daily local practice in the research area. The meal was very simple, with a small dish of boiled pork, homemade pickle gourd and vegetable soup. I was touched by the hospitality of the hosts when they kept making sure that I had enough to eat by putting food into my rice bowl. The pickle gourd and vegetable soup were very new to me, thus it was one of my most memorable meals in the field because of the new interesting 
food combination and the flavourful blend of simple local ingredients. After the meal, I helped the hostess cut the watermelon from their garden for desserts. We also went out to their garden to pick lemons. When they saw that I was taking photos of the lemon trees, they asked me to take some photos of them under their trees. That day I felt very happy, given the chance to interact with the locals in their daily life; their welcoming gestures made me feel closer and more able to fit in with the field itself.

Much of my observation was noted down in my notebook at night upon my recall of the day when I had returned to my hostel. I also used my phone to take photos when I wandered around the village and took notes of the happenings in my phone. The notes were later transferred to a summary note, either of the field or of the participants I had interviewed.

\subsubsection{Field notes}

Field notes are "the backbone of collecting and analysing field data" (Bailey, 1996 cited in Gray, 2004, p. 244); they comprise everything the fieldworker believes to be of importance (Gray, 2004). I was allowed to record my interviews with the research participants, so I was able to take side notes of my observations during the interviews. Field notes were also written after the interviews, and later were transferred to a computer alongside the interview transcriptions.

\subsubsection{Data recordings}

The recorder was utilized in most interviews to record the content of the conversations and to allow myself the freedom to note down my observations. This has proved to be immensely helpful for me because the data was fully captured in the recordings, so I was able to take side notes of the participant observations including their apparent feelings and body language, household livelihoods and facial reactions to the research question or to their recall of migration.

\subsubsection{Photography}

During fieldwork, various photos were taken in the field capturing the household livelihood, community and village surroundings. Some photos are featured in the data analysis as illustration. 


\subsubsection{Provincial documents and reports}

The materials were provided as the fieldwork proceeded in the field. After my conversation with the local leader of the first village I visited, he showed me an assessment report on the commune's progress and results of the implementation of the national programme on sustainable poverty reduction. Several materials and brochures on the provincial regular labour migration programme were given to me during the interview with the official from Ha Tinh DOLISA. He later sent me via email some reports and background presentations on the situation of regular and irregular migration from Ha Tinh. Those documents have been essential in constructing the background information for the context of this research.

\subsection{Data Analysis}

\subsubsection{Data transcription}

Most of the interviews were recorded with the permission of the interviewees. There was one participant who was concerned about being recorded, so I took notes manually during our conversation. The interview recordings were later translated into English during the process of transcribing. All interviews were conducted in Vietnamese and the researcher was solely responsible for the translation and transcription of the interviews into English.

\subsubsection{Data Analysis}

Data coding is not merely about data labelling, but rather bringing all the parts of relevant documents about a topic together so the researcher can review and develop the thinking about the topic (Richards, 2005). There are three types of data coding in qualitative research: descriptive coding, topic coding and analytical coding (ibid.). Descriptive coding is the initial step in data coding, when the researcher stores all information about the cases being studied. Topic coding is the process of labelling text according to its subject (thematic coding). Analytical coding, is central to the research. This is when the coding leads the researcher to theory emergence and theory affirmation (Richards, 2005). In the scope of this research, NVivo10 analysis software was used to code my research data. The interview transcription with the field notes were typed into Microsoft Word files and inserted into NVivo software for analysing purpose. Due to the 
free flow of the interview, the topics discussed were scattered and diverse, coding therefore was helpful for the researcher to organize data and explore the different dimensions of the data gathered (Richards, 2005).

\subsection{Ethical considerations}

Ethical consideration is essential in research to ensure that the research is not affected by the self-interest of any party and is not carried out in a way that harms any party (Kumar, 2014, p. 284). This research sought official ethical approval from Victoria University of Wellington's Human Ethics Committee before its realization. Through the guidelines of the ethics committee, I was aware of the requirements during fieldwork for the research to be in full compliance. The ethics guidelines stated clearly that ethical procedure and participant consent forms need to be obtained before any interviews. In detail, written consent explains the confidentiality of the research, gives the permission to conduct interviews and ascertains whether or not an interview can be recorded. Additionally, a consent form requests that the researcher explains to the interviewee their rights and options during the interview, and seeks the interviewee's permission to use their information prior to the interview.

However, as it appeared to me in the field, the mention of ethics procedures at the beginning of the conversation often set my participants in a cautious mode. They became cautious because of the unfamiliarity of such an ethical procedure. After my explanation of the purpose of the procedure, they were willing to sign consent forms and share their stories with me. However, I find it necessary to mention their cautious initial reaction. Ethics consideration, despite its importance and relevance in social research, sometimes requires negotiation in the Vietnamese rural setting. I committed myself to the ethical guidelines of VUW, however I was aware that my participants could become hesitant when issues of ethical conduct, rights and options were explained to them, therefore I spent the extra time needed to explain to my participants that conducting these procedures is crucial to protect their identification and participation in my research. I had to rely on my personal judgment to decide when they had become comfortable before I began asking them any research related questions. All the participants who expressed their initial concern regarding the ethics procedure appeared to 
feel more comfortable sharing when we began to talk, since none of the questions were threatening or prying into inappropriate matters.

All responses have been kept confidential and I made it clear that I would not discuss any of their responses with, or in the presence of, any other respondent. I explained to participants that they could go off record for questions deemed sensitive or uncomfortable to answer. All names of participants were changed to avoid any identification of the participants. The interview transcriptions were only accessible to the researcher.

\subsection{Summary}

This chapter discussed the qualitative methodology under the epistemology of social constructivism that guides my research. It explored the methods and tools used in the research to justify the reliability of the data collected. The chapter also reflected on my research experience in the field and touched on the challenge of balancing the 'insider' and 'outsider' selves when immersed in power relations during fieldwork. I also discussed the challenge of the ethical procedures for informed consent in those circumstances that required the researcher to be attentive and flexible to ensure full compliance of the conducted research, and, at the same time, to maintain a comfortable environment for the participants to express their views. 
This page is intentionally left blank 


\section{Chapter 4: Context}

\subsection{Introduction}

The first section of this chapter discusses key features of the social, economic, political and agricultural development contexts of Vietnam that inform this research. The second part of the chapter focuses on the geography, demography, environment, and basic economic development of the research location - Ha Tinh province. The second part also presents an overview of Ha Tinh's strategic location that contributes to the discussion of this research. This section informs the argument that Ha Tinh's strategic location and easy transportation within the Mekong sub-region play a critical role in boosting the flow of irregular labour migration from the area to neighbouring countries

\subsection{Vietnam Country Profile}

\subsubsection{Geographic and demographic features}

Vietnam, officially known as the Socialist Republic of Vietnam (SRV) is located on the Indochina Peninsula in South East Asia. Vietnam shares 4,550 km of land borders with China to the north, and Laos and Cambodia to the west. To the east is the South China Sea (See Figure 2). The S-shaped country stretches along a distance of 1,650 km from north to south, and its geography is categorized into three large regions - North, Central and South - with very distinct climates (Vietnam Government E-portal, 2016). The North consists of uplands and mountainous areas, and the Red River Delta; the Central region includes the coastal area along the Truong Son mountain range and the central highlands; the South embraces the south-eastern area and the Mekong Delta (Rowley \& Truong, 2009). 72 percent of the country's land area is mountain or hill and only 28 percent is plain (OECD, 2015). According to Food and Agriculture Organization (FAO) data in 2013, more than 35 percent of Vietnam's land area is agricultural land, of which 20 percent is arable (World Bank, 2015). Vietnam has a tropical monsoon and extremely humid climate. Climatic extremes in the form of too 
much or too little rain every six months of the year during the rainy season have disastrous effects on agricultural production (Rowley \& Truong, 2009).

Vietnam is a densely populated nation with more than 94 million people living on an area of 331,000 sq. $\mathrm{km}$; the population density is 296 people per sq.km. The Vietnamese rural population makes up 70 percent of the population, and agricultural labour accounts for 48 percent of the total work force (CIA, 2015). Vietnam has a young population with an annual growth rate of one percent and an increasing percentage of people in the working age group (World Bank, 2015). Given its high proportion of rural population, the majority of the Vietnamese labour force is low-skilled labour earning very low to minimum wage and facing high pressure of unemployment. 
Figure 2: Administrative Map of Vietnam

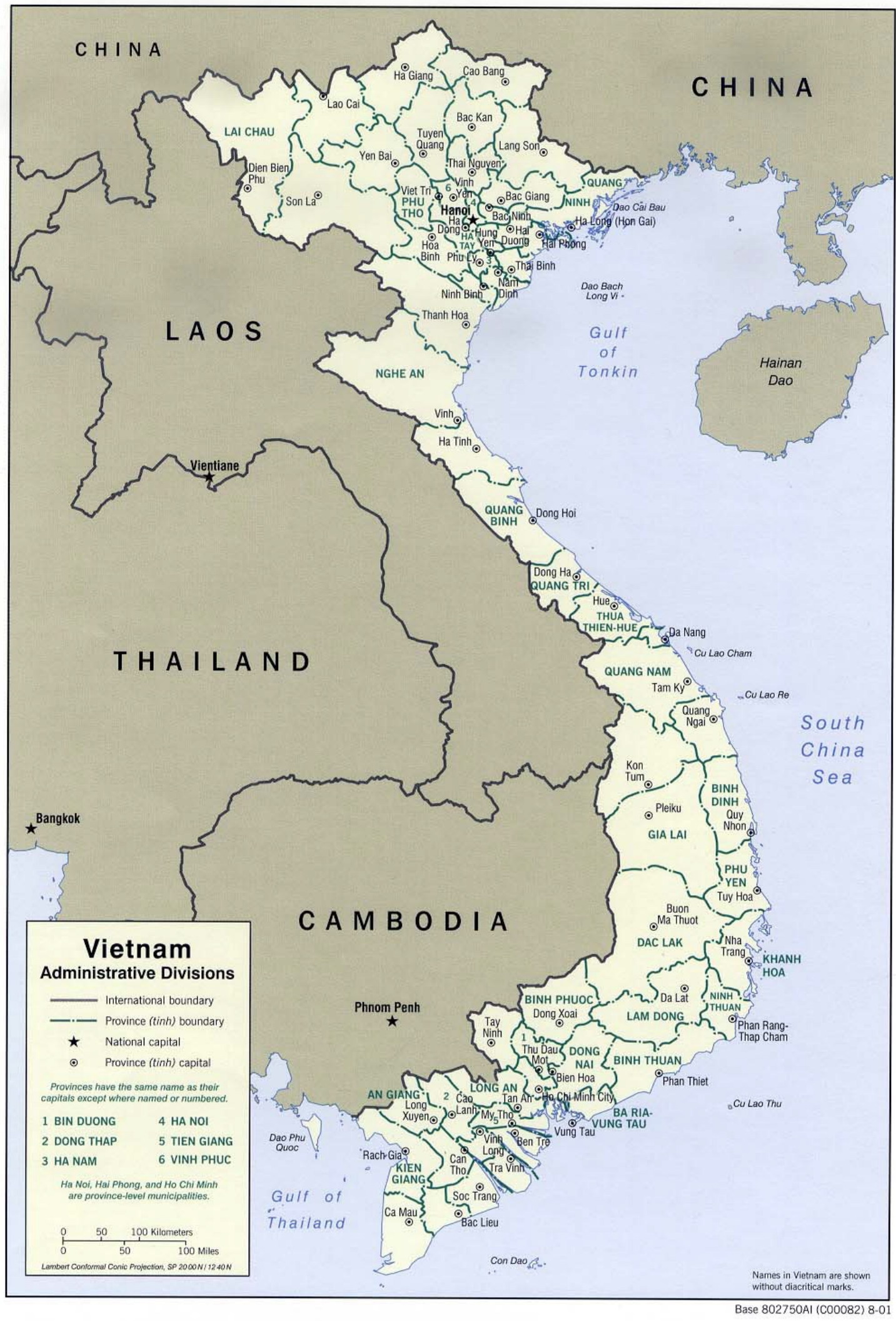

Source: (The University of Texas Library, n.d.) 


\subsubsection{General economic features}

Since 1986 when Vietnam embarked on its new economic reform (Doi Moi), the country has witnessed remarkable transformation in its development. Vietnam shifted its economy from a centrally-planned model which was described as a "bureaucratic centralized state subsidy system" (Litvack \& Rondinelli, 1999) to a more open market economy (Van Arkadie \& Mallon, 2004). The Vietnamese economy consists of four sectors: agriculture; industry and construction; trade; and services. Doi Moi, with its focus on the three elements of agricultural development, macroeconomic reform and trade liberalization (Adams, 2002), gained much credit as a "major turning point" in the economic development of Vietnam for transforming a poor, war-weary economy into a dynamic one with remarkable rates of economic growth and poverty reduction, especially during its peak period in the late 1990s (Harvie \& Tran, 1997). According to the World Bank, Vietnam's headcount index of poverty in 1984 was 75 percent - this indicator dropped significantly by one-half to 37.4 percent in 1997 (Dollar \& Litvack, 1998). In 2014, only 13.5 percent of the population fell below national poverty lines. Vietnam's Gross National Income (GNI) at the World Bank Atlas conversion reached USD 1,980 in 2015, placing the country in the low middleincome group of nations ${ }^{5}$ (World Bank, 2015). In 2014, Vietnam ranked 116 out of 188 countries and territories on the UN Human Development Index (UNDP, 2014).

Vietnam nowadays remains one of the dynamic emerging economies (Van Arkadie \& Mallon, 2004), the country's Gross Domestic Product (GDP) per capita growth has been among the fastest in the world since 1990 (World Bank, 2016), which is impressive for a country that, in the mid-1980s, was one of the world's poorest nations (OECD, 2015). Between 2011 and 2015, Vietnam averaged 6 percent per annum GDP growth (World Bank, 2015); the rate slowed during the

\footnotetext{
${ }^{4}$ National poverty headcount ratio is the percentage of the population living below national poverty lines. National estimates are based on population-weighted subgroup estimates from household surveys (World Bank, 2015).

${ }^{5}$ According to the World Bank, for the 2017 fiscal year, low-income economies are defined as those with a GNI per capita, calculated using the World Bank Atlas method, of USD 1,025 or less in 2015; lower middle-income economies are those with a GNI per capita between USD 1,026 and USD 4,035. (https://datahelpdesk.worldbank.org).
} 
first half of 2016 to 5.5 percent due to a severe drought affecting the agricultural production, and slower industrial growth (World Bank, 2016).

\subsubsection{Urbanisation}

Although Vietnam's economic transition has helped the country achieve high economic growth and remarkable poverty reduction results over the past two decades, the process also increased the gap between some of the poorest households and the better off, and between different rural and urban regions of the country (Booth \& Le, 2010; World Bank, 2013). Booth and Le (2010) found that, while the living standard of all Vietnamese people had increased, nonetheless an urban-rural expenditure inequality contributes to national inequality in Vietnam. Booth and Le (2010) also concluded that this inequality has a relation with internal migration. The rural-urban inequality, in the context of a more relaxed policy environment on internal migration since the early $2000 s^{6}$, has encouraged labourers to move from low wage to high wage regions more specifically, from rural to urban areas, and from low productivity to high productivity provinces (ibid.). Urbanisation has been progressing in Vietnam as people migrate from the agricultural sector to better paid jobs, which are mostly in urban areas (OECD, 2015). Data from the World Bank has shown a consistent rise in the percentage of urban populations in Vietnam from 1960 to the present, with a prominent increase from 20 percent in 1990 to 33.5 percent in 2015 (World Bank, 2015). The increase by half of the urban population in 25 years reflects the response of the people to Vietnam's rapid economic growth which is unbalanced between regions. The dramatic increase also creates major challenges for a more integrated development of rural and urban areas (OECD, 2015).

\subsubsection{Basic political features}

Vietnam is a socialist republic state with a one party system led by the Communist Party of Vietnam (CPV) since 1954 in the North, and since the reunification of the

\footnotetext{
${ }^{6}$ Internal migration in Vietnam used to be under tight control by the Vietnamese government from the Doi Moi period to the early 1990s. During this time, the Government set strict targets for rural people to migrate to cities; for example, to be eligible for migration to the cities, rural people needed to first own a house and have secured a job. The law on residence was amended twice in 2001 and 2006 to reflect less rigorous and more flexible regulations towards internal migration (Booth \& Le, 2010).
} 
country in 1975 over the whole country. The National Congress is the party's most senior institution, which meets every five years to elect Vietnam's CPV Central Committee. The Vietnamese Central Committee is the most powerful body, deciding Party affairs and government policy. The Central Committee adopts key policies and elects the Politburo and its Secretariat (OECD, 2015). These top party organs control and guide the National Assembly (NA), the Cabinet and the satellite organizations such as the Fatherland Front ${ }^{7}$, the General Confederation of Labour (trade union), and the Youth/Women/ Farmers Associations (Rowley \& Truong, 2009). There are 58 provinces and five cities beneath the central government, each with their own administrative subdivisions of districts, municipalities and communes. At the local and regional level, there are the People's Councils which are elected locally. Their executive bodies are the People's Committees, elected by the People's Council. These local and regional bodies supervise the implementation of central Government laws and regulations at their local level.

The top down governing structure allows the Government much leverage and limited opposition in its choice of policy directions and decisions (OECD, 2015; Rowley \& Truong, 2009). However, the top down approach often results in policy interventions that fail to address the needs of individuals at the grassroots level. For policies and regulations regarding migration specifically, migrants are generally viewed as a homogenous population with uniform needs, goals and abilities, while the reality is that they are highly heterogeneous (Dang et al., 2003). Dang et al. (2003) found that the results of direct policy interventions to affect migration have been limited. Because of this, one of the aims of this research is to highlight Vietnamese irregular labour migration with insights into the process, as well as the needs and priorities of the migrants when engaging with irregular migration; it also explores the development impacts that migration can offer, looking to shed light on a better understanding of the matter from the

\footnotetext{
${ }^{7}$ Vietnamese Fatherfront Land is an umbrella organisation for pro-government mass movements in Vietnam. It has close links with the Vietnamese Communist Party and the government of Vietnam. Its role is to promote "national solidarity" and "unity of mind in political and spiritual matters" in society.
} 
perspective of the people and communities on the ground. This in-depth understanding will help any policy intervention be more effective.

\subsubsection{Strengths and vulnerabilities in the Vietnamese agricultural context}

One of the great economic achievements of the Doi Moi process for Vietnamese agriculture was the growth of agricultural production within the country. Vietnam was able to solve its food shortage problems, ensure national food security, and grow from one of the world's low production nation to the world's second biggest rice exporter since 1989. From 2006 to 2010, the agriculture sector has grown at around 4 percent per annum. In the last five years, the growth rate has fluctuated significantly, between 2.6 percent in 2013 and peaking at 3.31 percent in 2014 - the highest rate over this time (Ministry of Agriculture and Rural Development (MARD), 2015). The majority of the workforce in the Vietnamese agricultural sector are small-scale farmers. Agricultural growth in Vietnam over time has been achieved through an increase in land use, a diversification into high-value crops, and effective use of material inputs such as labour, capital and fertilisers (OECD, 2015); however, the sector is now approaching its physical and financial limitations. Agricultural production has brought negative impacts to bear on the environment such as: biodiversity loss and degradation of natural resources, water pollution, land discoloration, and increased production costs, all of which threaten the sustainability of the sector's growth. In the future, natural resources for agricultural growth will no longer be abundant; agriculture will have to compete with the industry and other services sectors

The government has recognized the disadvantages of a low-quality agriprocessing sector, its lack of support services and infrastructure, as well as coordination among various actors that have resulted in low productivity, low value-added exports and low returns to farmers. Consequently, the Vietnamese government is placing greater emphasis on a market-driven approach for investments in the agriculture sector and the agricultural value chain. Accordingly, agriculture diversification is encouraged for production to be more responsive to market forces. This approach of market-oriented agricultural development is also a key element of the government's drive to eradicate poverty. 
The 2016-2020 socio-economic development plan introduced an initiative to restructure the agricultural sector towards increased growth value and sustainability (World Bank, 2016). It is suggested that agricultural development during this period should achieve high value-added, improved competitiveness and enhanced efficiency in production. Given that Vietnam has been a member of the World Trade Organisation (WTO) since early 2007, and has recently reached the Trans Pacific Partnership (TPP) agreement with 11 nations in the AsiaPacific region ${ }^{8}$, this strategy is relevant because it will provide opportunities for exporters of agricultural products to access a wilder global market, but it will also present challenges as farmers become more vulnerable to external influences and face possible exclusion from markets due to the inability to meet quality and food safety standards.

\subsection{Research location context}

\subsubsection{Ha Tinh's geographic and demographic features}

Ha Tinh is located in the North Central area of Vietnam, about $340 \mathrm{~km}$ south of Hanoi, bordered by Nghe An province to the north, Quang Binh province to the south, Laos to the west, and the Eastern Sea (South China Sea) to the east with $137 \mathrm{~km}$ of coastline (See Figure 3). Ha Tinh has a diverse topography including a hilly area, midland, plain and sea. The province's plain area is rather small and separated by the mountains and rivers. Ha Tinh has 14 large and small rivers and many lakes (Ha Tinh E-Portal, 2016). Ha Tinh province consists of one city (Ha Tinh city), two townships (Hong Linh and Ky Anh) and ten districts (Nghi Xuan, Duc Tho, Huong Son, Huong Khe, Vu Quang, Can Loc, Loc Ha, Thach Ha, Cam Xuyen, Ky Anh). The province is further subdivided into 12 townlets, 235 communes and 15 wards.

\footnotetext{
${ }^{8}$ On 20 January 2017, Donald Trump became the 45 th President of the United States of America and withdrew the U.S. from the TPP agreement; this significantly affected the scenario for the remaining 11 countries as the U.S. market was the biggest driver for their trade liberalization. Without the U.S., the TPP agreement would not have the same heft as the original, however the fate of TPP is still to be discussed. Vietnam's Ministry of Foreign Affairs made a statement indicating that "Vietnam will continue its reforming process and make better domestic preparation to fulfil the commitments of trade agreements of which Vietnam has been and will be a member" (Berlinger, 2017).
} 
Figure 3: Map of Ha Tinh

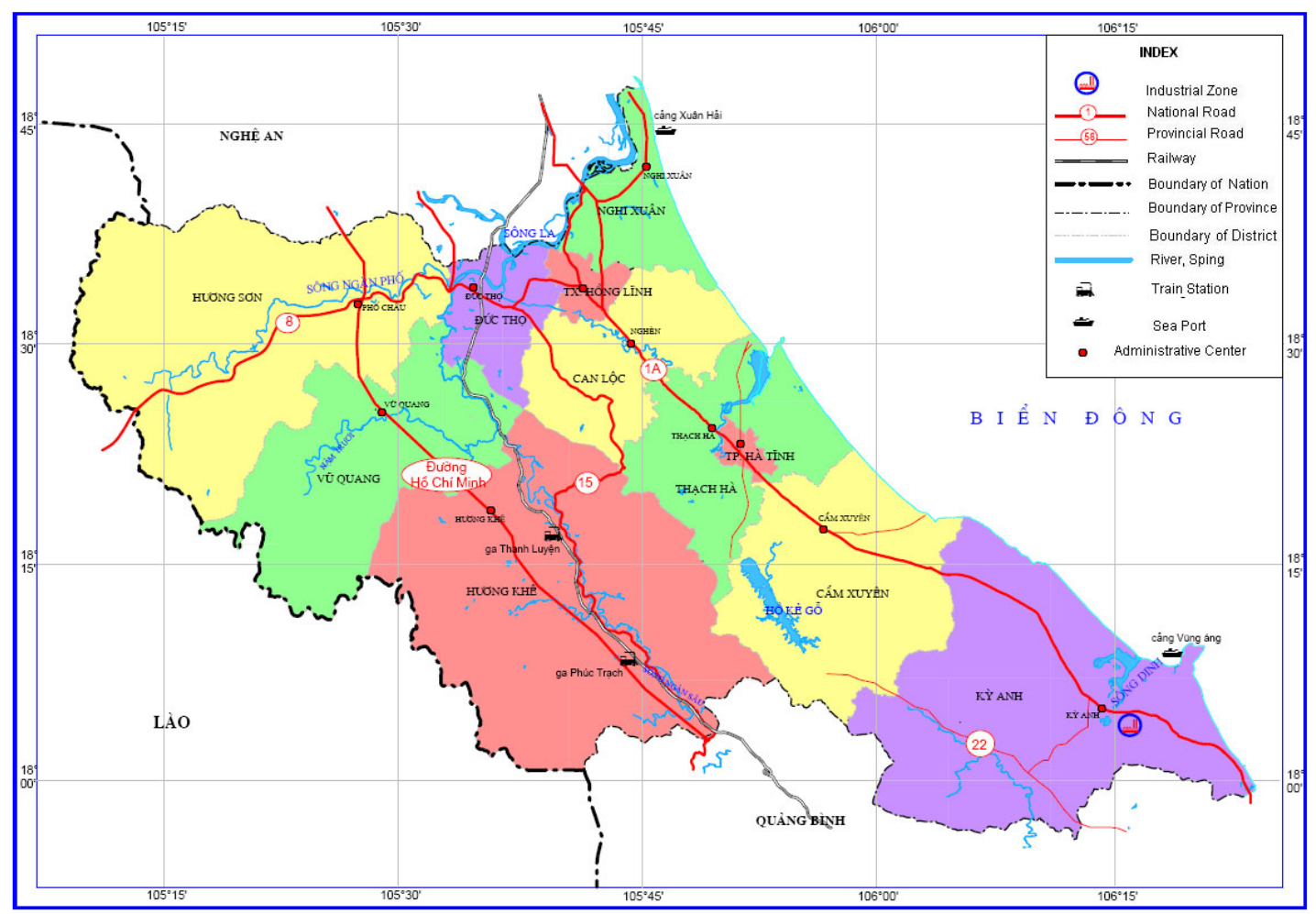

Source: (Vietnam Invest Network Corporation, n.d.)

Ha Tinh has a total area of 6,055.6 sq.km with a population of 1,280,782 according to data reported in 2015 (Ha Tinh E-Portal, 2016). The province has a population density of 203.6 people per sq.km with a slow growth rate averaging 0.45 percent over the past five years (GSO, 2015). One of the main reasons for the low population growth rate of Ha Tinh is out-migration to other provinces or abroad (Le et al., 2015). This is confirmed by the consistent negative net migration rate of the province over the past few years (-9.7 in 2010 and staying stable at -4 from 2013-15) (GSO, 2015). The population of Ha Tinh is primarily concentrated in the eastern coastal plain (Le et al., 2015). According to the Ha Tinh Department of Labour, Invalids and Social Affairs, an average of 10,000 people out-migrate annually from Ha Tinh (Ha Tinh DOLISA, 2016a). There are 745,300 people of labour age (15-60 years of age) in Ha Tinh; of this number, 44.7 percent work in agricultural sector (down from 63 percent in 2010), 26.62 percent work in construction, and 28.68 percent work in trade and services, as reported in 2015 (Ha Tinh DOLISA, 2016a). 


\subsubsection{Environmental features}

Ha Tinh province lies in the tropical area with regular, hot and humid monsoon and rain. The province is strongly influenced by the transitional climate between the Northern and Southern regions of Vietnam, featuring a typically tropical, hot climate in the South and freezing winter in the North. In general, the climate is very harsh in the province. Ha Tinh has two seasons: the rainy season from March to October (with rainfall accounting for 75 percent of annual rainfall) and summer from April to October. During summer, the province suffers from extreme heat, and the dry and hot southwest winds from Laos. The evaporation rate in the province reaches its highest from May to August every year. The annual average temperature is 24.7 degrees Celsius, however, during summer the temperature can average 32.9 degrees Celsius with the highest temperatures reaching between 38.5 and 40 degrees Celsius (Ha Tinh E-Portal, 2016). Over the last five years, Ha Tinh has experienced a complexity of weather and climate change. The average temperature in the region increased by 0.25 degrees Celsius since 1981 to 2011 (Le et al., 2015). The average regional precipitation has been observed to fluctuate. What is more, other significant changes in humidity and evaporation, the unusual appearance of high frequency and complexly moving storms, and tropical low pressure under the impact of climate change, have all intensified the severe climatic conditions of the region (Ha Tinh E-Portal, 2016) and will probably continue to do so.

\subsubsection{Ha Tinh's economic features}

Ha Tinh has a less developed economy in comparison with other provinces of Vietnam. Its annual economic growth rate increased from 11 percent in 2010 to 19 percent in 2013 (Le et al., 2015) while GDP per capita was 44 million VND (approximately 1,970 USD) in 2015 (Ha Tinh DOLISA, 2016a). In recent years, the provincial economy has improved significantly due to the rapid development and contribution of its industrial sector since the operation of the Vung Ang Economic Zone in 2006. This economic zone on its own contributed 42 percent to the provincial revenue budget in 2015 (Tran, 2016). However, the rapid growth of Ha Tinh is not translated into economic improvement across the board for all its population. While 85 percent of the population live in rural areas (Le et al., 2015), their living conditions are still fairly poor. The poverty in $\mathrm{Ha}$ Tinh can be 
attributed to the harsh natural conditions in the region with severe climates and unfavourable soils. The total value of agriculture, forestry and fisheries in the province increased by double between 2010 and 2013, but its share in GDP decreased from 30 percent to 23 percent (Le et al., 2015). Major industrial products include apparel, pharmaceutical drugs, wood products, green tea, mining products and construction materials (Nguyen, 2012). Within the agriculture sector, the largest share of production is from crop production (50 percent), though this has declined from 62 percent in 2010 to 54 percent in 2013. The main crops of Ha Tinh are rice, peanut, orange, tea, rubber, pomelo, sweet potato, cassava, bean, maize and vegetables (Le et al., 2015).

There are two Special Economic Zones (SEZ) in Ha Tinh: the Cau Treo International Border Economic Zone which covers 560 sq.km (established in 2013), and the Vung Ang Economic Zone of 227.8 sq.km (established in 2006) (Ha Tinh Economic Zone Authority, 2017). Vung Ang was established with the intention to utilize the region's ports at Vung Ang and Son Duong. Vung Ang EZ mainly focuses on heavy industry. There are two foreign direct investment projects in Son Duong, run by Taiwanese Formosa Heavy Industries with a total registered capital of USD 7.89 billion (Nguyen, 2012). The establishment of the two economic zones contributed greatly in providing labour employment for local people. In 2016, the Formosa Ha Tinh Steel Plant released deadly heavy metal and chemical toxins into the sea of Ha Tinh, killing millions of fish along the Central Coast of Vietnam and endangering the lives of its people through subsequent poisoning. The release of toxic chemicals from the massive industrial plant in Vung Ang has been reported to be one of the largest environmental disasters in Vietnam's history. The Steel Company admitted to the case in June 2016 after much tension caused by Vietnamese and offered USD 500 million in compensation (RFA, 2016).

\subsubsection{Ha Tinh Strategic Location}

Ha Tinh enjoys a strategic location in the North Central Coast of Vietnam, bordering Laos to the west and the South China Sea to the east. The location has been beneficial for its trading and economic development. Since French colonization, a lot of focus was put into the transport network in Central Vietnam 
in order to connect Laos to the ocean (Nguyen, 2012). The French invested heavily in three transport networks in the central part of Vietnam - routes, ports and airports - during the late 1890s and early 1900s (Nguyen, 2012). Specifically, they started the construction of:

- Route No.9 from Laos' Savannakhet to Dong Ha, Quang Tri, Vietnam in 1895;

- $\quad$ Route No. 8 from Borikkhamsay (Laos) to Hong Linh, Ha Tinh in 1903.

- $\quad$ Route No. 9 and Route No. 12 (from Thakhek, Laos to Ba Don in Quang Binh province), open in 1930

- $\quad$ Route No. 7 from Luang Prabang to Dien Chau, Nghe An, put into operation in 1937.

In 2011, the Third Thai-Lao Friendship Bridge over the Mekong River was officially opened. The bridge serves as an important infrastructure facilitating cross-border trade along Asian Highway 15 (Route No. 8) and Asian Highway 131 (Route No. 12) between Northeast Thailand, Central Laos and North Central Vietnam (See Figure 4).

Figure 4: Map of the Third Thai-Lao Friendship Bridge connecting to Ha Tinh

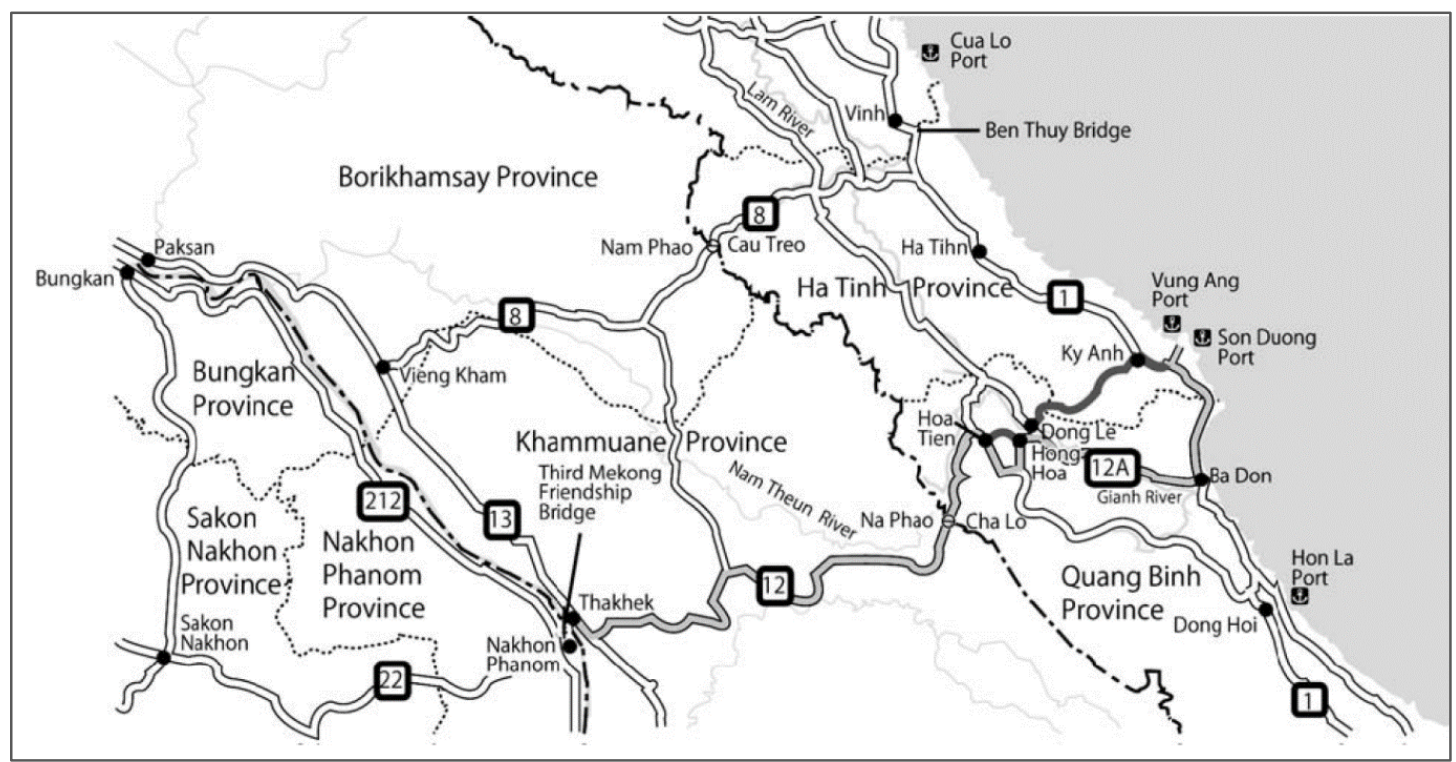

Source: (Nguyen, 2012). 
When the East-West Economic Corridor (EWEC) was established in 1998 (ADB, 2010), the cross-border trade among countries in the Greater Mekong Sub-region was facilitated much further (ADB, 2010; Nguyen, 2012). The EWEC was considered one of the flagship initiatives of the GMS to target some of the poorer areas of the GMS countries through a cost-effective way of instituting an efficient transport system for goods and people in the sub-region (ADB, 2010). The location in Central Vietnam clearly benefits Ha Tinh as a well-connected hub to major transport infrastructure in the region.

\subsection{Conclusion}

In this chapter, I have discussed the geographic, economic and political features of Vietnam as the general context of the country where this research is undertaken. Then I featured, in more detail, the research location - Ha Tinh province. It can be seen from this chapter that a number of Ha Tinh's characteristics make it a prime location for out-migration. The harsh climatic conditions make agricultural cultivation difficult, while its connection to other parts of the region enables easy travel to neighbouring countries. In addition, the recent environmental catastrophe which poisoned fish along the coastline has impacted on what are already rather marginal rural livelihoods. Given these conditions, it is unsurprising that many local people seek to diversify their livelihoods through temporary migration. What I have found through the context study of my research location is that while Vietnamese policy applies a top down approach for interventions, the increasing rate of out-migration from Ha Tinh, much of which is irregular, undocumented migration, calls for a more in-depth, contextual intervention should irregular migration be regulated in order to optimize temporary mobility as a strategy to sustain rural livelihoods. The findings presented in the following Chapter (Five) portrays how irregular migration has been adopted as a livelihood strategy for the local people of $\mathrm{Ha}$ Tinh; it also investigates the range of reasons why irregular migration is more preferable for them than regular labour migration. 
This page is intentionally left blank 


\section{Chapter 5: Irregular Migration as a Livelihood Strategy}

\subsection{Introduction}

This chapter presents and discusses the findings of the fieldwork that I conducted in June 2016 in four villages of Ha Tinh province. It addresses my two central research questions, asking (i) How irregular migration emerged as a livelihood strategy in the rural context of Ha Tinh, and (ii) the range of reasons why local people decided to engage with irregular migration. The first part of the chapter divides my research participants into three different categories based on participants' age, but which show up clear distinctions in motivations and characteristics as well. This categorization is useful in understanding how and why different groups of people respond to irregular migration, which is then discussed in the following sections of the chapter.

The second part examines the significance of irregular labour migration as an appealing means to diversify rural household incomes to sustain livelihoods. It captures the change in perceptions of rural people about farm work, and explores their desire to steer their future generations away from farm work. This transition is one of the reasons why mobility is likely to be encouraged from the rural areas of Ha Tinh.

The third part of the chapter investigates the differences between regular labour migration through official channels and irregular labour migration through unofficial channels from the migrant workers' perspective. This analysis sheds light on the framing of irregular migration under the labour migration push and pull framework, presented in the section following.

The last section of the chapter addresses the decision-making process and the range of reasons why local people chose to migrate irregularly. This is conducted through an examination of three key influencing factors - finance, social networks, and distance between home and destination countries. 


\subsection{Categories of irregular migrant workers according to age and motivation}

I conducted interviews with 13 irregular migrant workers for this study, of which five were male and eight female. It became clear that motivations for migrating differed according to the life stage of each participant. Therefore I divided the participants into three categories based on their age and hence their primary motivations for migrating.

The three categories are: (i) senior people in their mid-40s to early 50s, (ii) middle-aged people in their late 30s to mid-40s and (iii) young people freshly out of basic education, in their late teens to early 20s. The largest group of irregular migrant workers fell into the second category, while the youngest group was the smallest. This fits with the finding that most young people of labour working age were absent from the countryside having already left, either attending vocational school or higher education elsewhere, or migrating for work internally or externally. This group was few in number, and it was also found to be the most flexible group of irregular migrant workers. Besides the obvious financial purpose, one young worker migrated irregularly due to curiosity and the boredom of staying in the countryside. In another case, a young informant opted for irregular migration to China after being sent home from Malaysia, where he'd failed to meet the health check requirement after a year working there through the official labour export programme. When his friends asked him to join them in China, he decided to follow them. Both of the younger irregular migrant workers had returned home and were considering their options for future livelihood betterment, however, they expressed their uncertainty of migrating irregularly again. The parents in both cases shared a similar view, wishing for their children to "have stable jobs, possibly migrating through official channels and being protected in a safe working environment" (Informant 11.1), rather than working illegally overseas.

Unlike the younger generation, the other groups of irregular migrant workers seemed to have fewer choices. To maintain or improve their living conditions, they had adopted irregular migration as a non-agricultural economic strategy, while family members who stayed behind continued with existing farm work. For 
both groups of older migrant workers, irregular migration offered the opportunity to earn better money on a regular basis to support their families, while at home their chance to access paid jobs was less likely compared to the younger generation.

The group of migrant workers in their mid-40 to 50 s were all females who migrated to work as domestic workers. Due to the nature of domestic work associated with women, there were no male workers found migrating for this type of job. While the women were likely to find similar jobs in the local market, most were driven by better pay in destination countries and the ability to remit most of their earnings home, since their food and accommodation were often provided with the job. When asked about her decision-making, one female in her 50s shared, with determination: "I didn't ask much for consultation. I've known people who went abroad to work and made better money. I heard them say that in Thailand there are many jobs suitable for my age, so I went" (Informant 14).

For the group of middle-aged migrants in their 30 s to 40 s, irregular migration was an option that worked for the family. The workers in this group were found to be the most dynamic in terms of migrant flow. This group had the largest number of workers, working a variety of jobs in both genders and at their best in terms of labour productivity. Many informants in this group said that they would never think of working overseas through the official labour export channel because of the relatively high cost. Regular labour migration was considered an investment that not everybody could afford. In addition, regular labour migration, with its strict rules and training requirements, as well as the commitment to long-term work contracts, was not as flexible for this group of migrant workers who tended to be settled with their families, with children and elderly people in the countryside. For these workers, irregular migration, though risky, was more affordable and flexible. With irregular migration, migrant workers could go abroad for a certain amount of time to work for money, but still maintain a close connection with their family, attending to family business such as being home when older relatives were sick; and, if they were careful, they could work well and return home safely (Field notes, 2016). Table 3 below shows groups of irregular migrants divided by age. 
The irregular economic migration studied in this research falls into the typical pattern of the gender-segregated labour market in the case of labour migration in the global south. Accordingly, male migrants were often employed in production industry while female migrants were associated with mundane repetitive tasks and low-skilled service jobs (Elson 1995; Pyle 2011 cited in Beazley \& Desai, 2014, p. 412). Among the five males, three worked in construction in two different destinations, one worked in a kitchenware factory and one for a wood factory. The eight female irregular migrant workers worked as live-in kitchen hands, housemaids, and caretakers of seniors or children. This research found that each of the migrant households chose to send one family member overseas based on the relevance of that person's skills for the job market where they migrated (see Table 3) 
Table 3: Category of irregular migrants divided by age groups

\begin{tabular}{|c|c|c|c|}
\hline $\begin{array}{c}\text { Category of } \\
\text { migrants }\end{array}$ & Characteristics of migrants & $\begin{array}{c}\text { Jobs in } \\
\text { destination } \\
\text { countries }\end{array}$ & $\begin{array}{l}\text { Purpose of } \\
\text { migration }\end{array}$ \\
\hline $\begin{array}{l}\text { Senior } \\
\text { migrant } \\
\text { workers }\end{array}$ & $\begin{array}{l}\text { Gender: all female } \\
\text { Age: mid-40s to early } 50 \text { years } \\
\text { Family status: married with } \\
\text { teenaged children or older. } \\
\text { Some have children with their } \\
\text { own dynamic family; some } \\
\text { have children who are also } \\
\text { migrant workers } \\
\text { A strong sense of family } \\
\text { responsibility towards their } \\
\text { own and their children's } \\
\text { family or career business }\end{array}$ & $\begin{array}{l}\text { Domestic } \\
\text { workers: } \\
\text { - Live-in care } \\
\text { taker for old } \\
\text { people or } \\
\text { babies } \\
\text { - Kitchen } \\
\text { helper }\end{array}$ & $\begin{array}{l}\text { - Housing } \\
\text { improvement } \\
\text { - Support their } \\
\text { children's } \\
\text { education } \\
\text { - Support } \\
\text { children's debt } \\
\text { repayment }\end{array}$ \\
\hline $\begin{array}{l}\text { Middle-aged } \\
\text { migrant } \\
\text { workers }\end{array}$ & $\begin{array}{l}\text { Gender: male and female } \\
\text { Age: } 30 \text { s to mid- } 40 \\
\text { Family status: married with } \\
\text { children of school age } \\
\text { Settled their family in the } \\
\text { countryside } \\
\text { At the best of their health and } \\
\text { productivity } \\
\text { Family responsibilities include } \\
\text { taking care of their own } \\
\text { family and looking after } \\
\text { older generation in the } \\
\text { family }\end{array}$ & $\begin{array}{l}\text { - Construction } \\
\text { workers } \\
\text { (males) } \\
\text { - Live-in } \\
\text { maids } \\
\text { (females) } \\
\text { - Live-in care } \\
\text { takers } \\
\text { (females) }\end{array}$ & $\begin{array}{l}\text { - Family } \\
\text { improvement } \\
\text { - Support } \\
\text { children's } \\
\text { education } \\
\text { - Savings } \\
\text { - Debt } \\
\text { repayment }\end{array}$ \\
\hline $\begin{array}{l}\text { Young } \\
\text { migrant } \\
\text { workers }\end{array}$ & $\begin{array}{l}\text { Gender: all young males. There } \\
\text { were young female irregular } \\
\text { migrants as I was told, } \\
\text { however I didn't have the } \\
\text { chance to meet any during } \\
\text { my fieldwork } \\
\text { Age: early 20s } \\
\text { Family status: single without } \\
\text { children } \\
\text { Flexible family responsibility; } \\
\text { focus on their future career }\end{array}$ & $\begin{array}{c}\text { - Factory } \\
\text { workers }\end{array}$ & $\begin{array}{l}\text { - Earning } \\
\text { financial } \\
\text { support for } \\
\text { their future } \\
\text { plan } \\
\text { - Trying new } \\
\text { things } \\
\text { - Boredom of } \\
\text { life in the } \\
\text { country side }\end{array}$ \\
\hline
\end{tabular}


As mentioned previously, from my observation, not all the rural people in the villages responded to irregular migration (Field notes, 2016). However, those who chose to migrate irregularly expressed a strong economic motivation underlying their migration. The migratory purposes of each age group differed according to the life-stages of the migrants. While younger people were found to be curious about the world around them and migrated to accumulate savings for their future plans, the middle-aged group of migrants focused on working overseas to improve the livelihoods of their families. The oldest group of migrants wanted to earn money to improve their housing conditions as well as to provide financial support for their children who had married and had their own nuclear families.

The views shared within the three different groups of irregular migrant workers respectively reflected the differentiated dynamics of different generations of migrants. This suggests that the roles of each generation of migrant workers reflected the family responsibility they assumed in a traditional family. The younger group was quite flexible with their roles in the family, and, not yet having their own families, had the freedom of mobility. Since they were younger, they could rely on their parents to assume family responsibilities. In contrast, the parental generation in the countryside was less mobile due to family responsibilities and a strong sense of being rooted in the place where their ancestors had lived and accumulated the assets their families later inherited. In Vietnamese culture, with age, one assumes more responsibility, caring for parents and paying tribute to ancestors. The oldest group of migrants were not only responsible for their own family businesses, but also had the tendency to help any married children with some of their family responsibilities.

\subsection{How is irregular migration a livelihood strategy?}

\subsubsection{Irregular migration as a means to diversify family income sources}

Migration has been an important means of sustaining livelihoods for local people in rural areas in Vietnam (Winkels \& Adger, 2002). In fact, Jonathan Rigg has highlighted that the "growing role" of migration and mobility in livelihoods in the rural south has come to be generally acknowledged (Rigg, 2006, p. 181). A common practice shared among the local people in the villages where my 
research interviews were conducted supported this view. Specifically, I found that having a family member working away from home is a normal practice for many households in the province (Field notes, 2016).

Most of the research informants implicitly expressed their loss of interest in farm work due to the low productivity of land, harsh climate, and low-earning potential of agricultural activities (Field notes, 2016). A report on labour migration in the Greater Mekong sub-region (Caouette, Sciortino, Guest, \& Feinstein, 2006) pointed out that Vietnam, with a large proportion of the population still engaging in agriculture, was in the midst of a process of urbanisation with an enormous number of internal migrants moving to urban and semi-urban areas. Some of the main reasons for this movement were reportedly the lack of access to capital, productive land and technological knowhow and tools, all of which limited farmers from competing in emerging agricultural markets (ibid.). This explained why farmers were being pulled to the rapidly expanding sectors of construction, services and manufacturing (Caouette et al., 2006). Ten years later, during my interviews with the migrant workers who were all rural residents, exactly why agriculture has failed to sustain rural livelihoods was still being discussed with similar reasoning. Many informants mentioned that they had to work from early morning till late at night on the farm, even then only earning enough for the family to survive. They therefore opted for irregular migration. In this case study, I investigated how the scale of labour migration, as a response to the pull of rapid economic development, has reached beyond regional borders to encompass international migratory routes. Vietnam's impressive rate of economic growth over the past ten years has obviously changed the economic scenario of the country, in both urban and rural areas, however, it does not seem to have significantly reduced the gap between rates of development in urban and rural areas. 
Figure 5: The road that runs along one of the villages

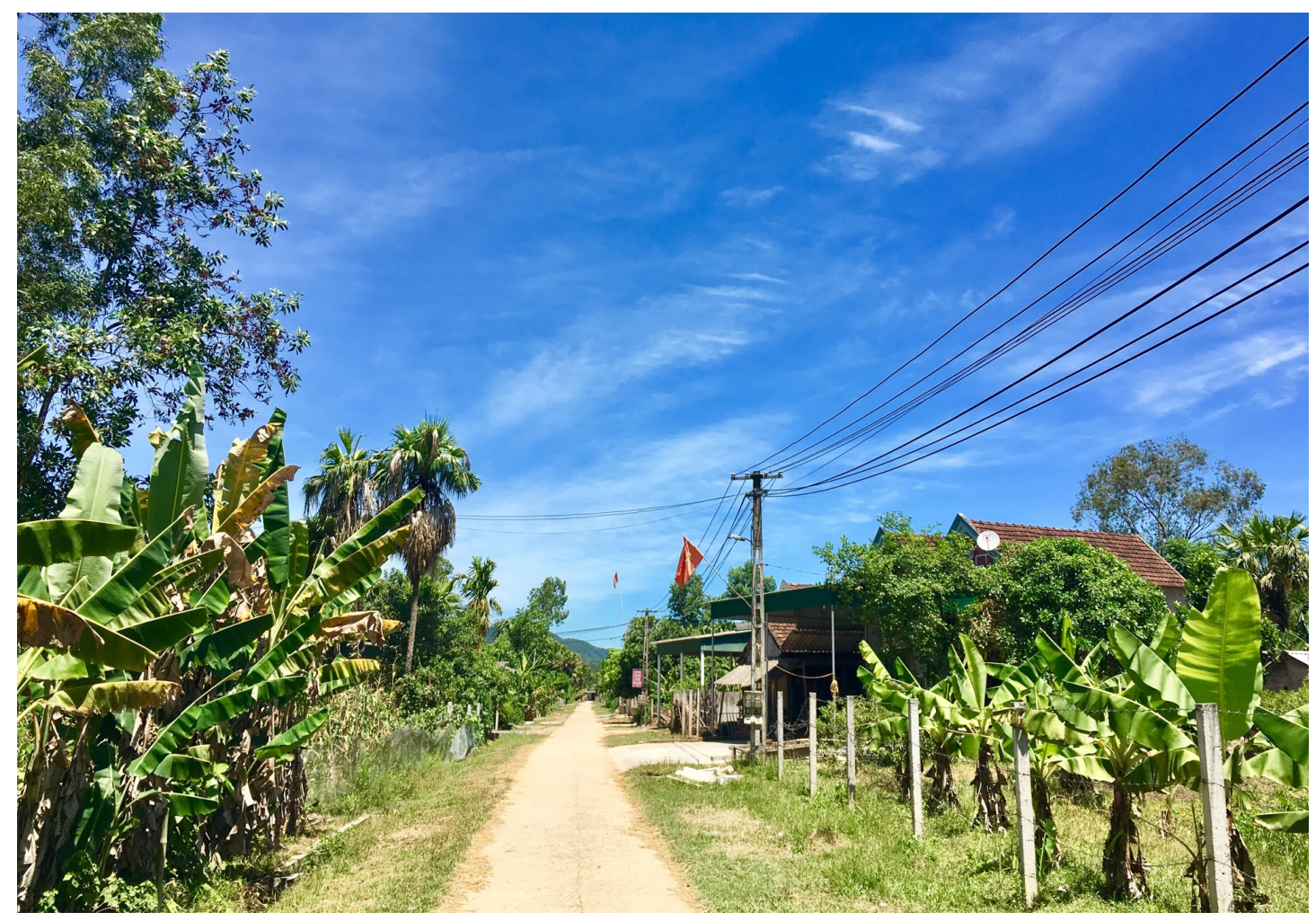

Photo taken by author during fieldwork, June 2016.

Ha Tinh has a harsh climate and poorly conditioned soil where rice cultivation is seasonal (mainly planted in the rainy season) and highly dependent on the weather and soil quality. Figure 5 above is a photo taken on one of the hottest days of summer in one of the villages where I conducted my research interviews. The weather reached 40 degrees Celsius at noon. During this time of day, people were advised to stay indoors to avoid the severe heat. Many of the research participants said that they could only farm for six months of the year, thus, incomes are not stable (Field notes, 2016). In order to ensure the family's subsistence, out-migration has for some time been an economic strategy for local people looking to diversify their household sources of income for greater stability.

Through interaction with research informants, I learned that irregular migration via unofficial channels has been ongoing for more than a decade in this part of the country. Along with other types of regular migration in the region, such as rural to urban, rural to rural, and international labour migration through official recruitment companies, irregular economic migration is found to also help the 
local people sustain rural livelihoods (Field notes, 2016). As rural households strived towards income diversification, often agriculture remained the livelihood strategy of those who stayed back in the countryside. On one hand, the families of the migrants maintained their farming activities as one source of income, and on the other, the remits of the migrants themselves were another important financial resource for the family. In this regard, an irregular migrant worker shared: "My wife managed her [farm] work and the kids helped out with farm work too. Since I'm away she had to outsource some work with the rice husking, things I was in charge of when at home she now outsources. So we have our income from the farming still and then the extra that I earned working in Laos" (Informant 02).

In their 2008 study on temporary rural to urban migration in Vietnam, Pham and Hill (2008) found that those who migrated still retained their foothold in the rural areas. This research resonates with this point; especially in the case of irregular labour migration, when the migration is supposed to be temporary for economic purposes, it is very important that migrants retain their family ties and a foothold in the village while remitting home from afar. Doing so ensures that migrant workers and their families have different sources of income to sustain their lives and cope with any shocks to livelihoods. At the same time, the foothold in the rural area can ensure that the irregular migrant can return home if there is any family business that requires their presence, re-joining the family farming business should migration no longer be the choice for them (Field notes, 2016). From this we can confirm that irregular migration is a household calculated strategy to ensure that the family have different sources of income to sustain and improve rural livelihoods.

\subsubsection{A change of perception about rural farm work}

In rural areas there is a general belief that associates farming with poverty and low social status. In addition, many people have commented that "farm work is hard work and low-earning" (Field notes, 2016). It is thus normally the case that parents would not wish for their children to stick with farm work if they have other choices (Informants $04,05,07,15$ ). Therefore, migration and mobility come to play an essential role for the local people as an option besides farming. Rigg 
found in his study in the rural south that, especially in South East Asia countries, (i) education, social media and consumerism have gradually changed rural people's ideas about the continuation of rural work and farming in their children's future, and (ii) since farming is believed to be a low status occupation, younger people express a strong wish to build their future avoiding farming (Rigg, 2006, p. 189). In line with Rigg's finding, all of the irregular migrant workers whom I interviewed confirmed that they are becoming more open about their children's choices for the future: their children do not necessarily have to continue their farming legacy if they do not wish to. The participants explicitly expressed a desire for their children to have a better future than they had, so moving out of farm work was encouraged (Field notes, 2016).

Through my interaction with the irregular migrant informants, I sought to investigate whether young people did, as Rigg suggests, seek to build their future away from farming. Both of the young participants in this research shared a view similar to Rigg's finding. I met with these young men when they had just moved back home after their irregular migration. Both said that they were staying home at that moment to help their parents with farm work, but also that they would soon find jobs somewhere else and leave the village. Since most of their friends had migrated for work elsewhere, both the young men expressed the wish to do the same, as they found living in the village and farming quite boring (Informants 11 and 12).

Within the scope of my research, I was able to also verify this argument from the perspective of the parents, since most of my research informants were of middleage and older, all of whom were married with children. While Rigg suggests that young people want to build their careers away from farming because it is considered a low status occupation, the viewpoint of the parents was slightly different. They argued that there was a need to move away from farming not only of its low social status, but also because it was hard manual work and poorly remunerated.

Whatever the reasons, this finding reflects a strong desire among rural people in the area to steer future generations away from farming for their livelihoods. Parents themselves had pursued careers outside farm work and seen first-hand 
how other livelihood options, such as those offered by irregular migration could make a difference to their situation (Informant 04).

My findings show that the older generation did not respond to the low status of farm work as strongly as the younger generation. Older irregular migrant workers, as parents, were living partially disconnected from farm work, in order to pave the way for future generations to realize their options in moving away from farm work. All participating migrant workers expressed their wish for the children to escape poverty and hard work on the farm, and migration (not necessary irregularly), in their view, is a realistic strategy to attaining this desire. It is worth noting that with the fragility of the irregular migration process and the risks it entails, 90 percent of parents who had migrated irregularly did not want their children to migrate the same way. In sum, this study finds that low social status was one, but not the most, important driver for research participants to distance themselves from farming in the rural area; it was the hard nature of agricultural work and its low economic impacts that more urgently pushed people away from farming towards other options. Irregular economic migration was chosen as a means of livelihood diversification, but not necessarily out of a concern for the low social status of farming. The work opted for through irregular migration was, after all, illegal, low-skilled and had a similar level of social status. However, low-skilled irregular migration was seen as a means of elevating people out of rural poverty towards economic betterment.

\subsubsection{The old poverty and the new prospect}

Rigg argues that the production and reproduction of poverty in the new rural south are becoming delinked from land and agricultural resources more widely (Rigg, 2006, p. 183). He describes a poverty transition from old poverty to new poverty as the gradual move from agriculture-based livelihoods to the adoption of landless, non-farm activities in rural areas. "Old poverty" according to Rigg, is "inherited" (Rigg, 2006, p. 190), meaning the poverty that is a product of resource failures, limited land use and low productivity of land in the rural south is transferred from one generation to another. This type of poverty is dependent on traditional technology, limited income and remoteness from the resources of the state and market. On the other hand, the "new poverty" is reproduced through 
the rapid diversification of rural livelihoods, market integration of rural households and communities into the economic mainstream, a noticeable increase in mobility, and a proliferation of opportunities outside farming (Rigg, 2006, p. 194). The view gained during this research fieldwork indicates similarly the preferred "de-linkage" from land and agricultural resources, especially, but not only, for the younger generations in rural villages. While parents can be seen as the key actors in the transition between the two forms of poverty, their wish for children to move away from farm work and consider non-farming activities as a livelihood option is becoming more recognised (Field notes, 2016). In this way, parents are not only transitional actors, but also the principle sources in supporting their children to create futures outside farm work (Field notes, 2016). This research wants to adapt the understanding of poverty used by Rigg. Specifically, for many participating irregular migrant workers and their families, their migration, though irregular and illegal, is more likely considered as "the new prospect" to combat their "old poverty".

\subsubsection{The role of education in the rural area}

According to 2016 data from Ha Tinh's Department of Labour, trained labourers in Ha Tinh number approximately 15,000 annually, however, the province can only accommodate employment for 5,300 (Ha Tinh DOLISA, 2016a). Already the number of trained labourers from Ha Tinh who have to migrate for employment is around 10,000 per year (ibid.). Besides the portion of trained migration, a significant amount of out-migration from the countryside is untrained and lowskilled based on the level of education of the migrants. The issue of education was not included in any of the questions posed in the interviews, but the topic arose nonetheless in the discussion with most of the informants. As reiterated by a parent I met in the village, most rural parents are so occupied with doing farm work and making ends meet on a daily basis that they do not have the time to help their children with study (Field notes, 2016). While there are other important factors that affect a child's learning experience, such as the quality of the educational system in the rural area and the roles of the educators, most of my informants expressed a general concern about their roles as parents in their children's education. The majority of the irregular migrants with children of school age shared that they were not spending time helping and encouraging 
their children with study, and felt that this resulted in them not doing very well in school.

Even though this was the general comment from parents in the interviews, there are undeniably other influential factors that can determine a child's educational failure or success. In some cases, the child's aspiration and passion for education can be the driving force to help them excel in school without their parents help (Case of informant 05). For informant 15, support from parents played an important role in helping their children to succeed in education. Informant 15 worked for ten years in Thailand to ensure her three children had the financial support necessary to enter higher education, and that they could focus completely on their study without having to work part-time jobs to survive. At the same time, her husband strategically stayed at home to take care of their farm work and, most importantly, to encourage and support their children with their study in basic education ${ }^{9}$ to prepare themselves for higher education (Informants 15 and 15.1). The husband said: "I literally studied with them, so I knew what they study and could help them when they had questions. I only finished grade 10 back in the days when I was in school, so I had to learn with them now in order to teach them. When the kids were at school, I studied their books whenever I finished farm work". In this case, the family's calculated strategy was for the mother to work overseas to ensure they had the finances to help all three children gain their higher education, while the father who stayed back was highly supportive of the children's study in a direct and practical sense. The farm work that the father maintained at home also contributed to their daily livelihood. The mother recalled with determination: "The moment my youngest child finished his university, I immediately stopped [working illegally] and moved back home" (Informant 15).

\footnotetext{
${ }^{9}$ Basic education refers to Vietnam's education system, consisting of primary school (age 6-11), middle school (age 11-15), and high school (age 15-18). Primary education is compulsory for all citizens, middle school is compulsory for the job market, one has to finish middle school to enter either vocational school or the job market, and high school is compulsory only for those who want to pursuit higher education.
} 
It is obvious that each household is different, and that the connection between the role of the parent and the educational outcome of the children varied from case to case. Since education was not within the scope of this study, the factors that influenced education in the researched area cannot be generalized and would benefit from further investigation. However, to my understanding gained during fieldwork, as much as rural parents want for their children to excel in school, they have come to accept that busy farm work prevents them from nurturing their children's passion for and dedication to education. Study is therefore solely left in the hands of the children themselves. In addition to having to take care of their own study, most rural children also need to spend time each day helping with farm work and household chores such as cooking, cleaning and taking care of younger siblings (See Figure 6).

Figure 6: Children helping out with farm work: herding buffalo.

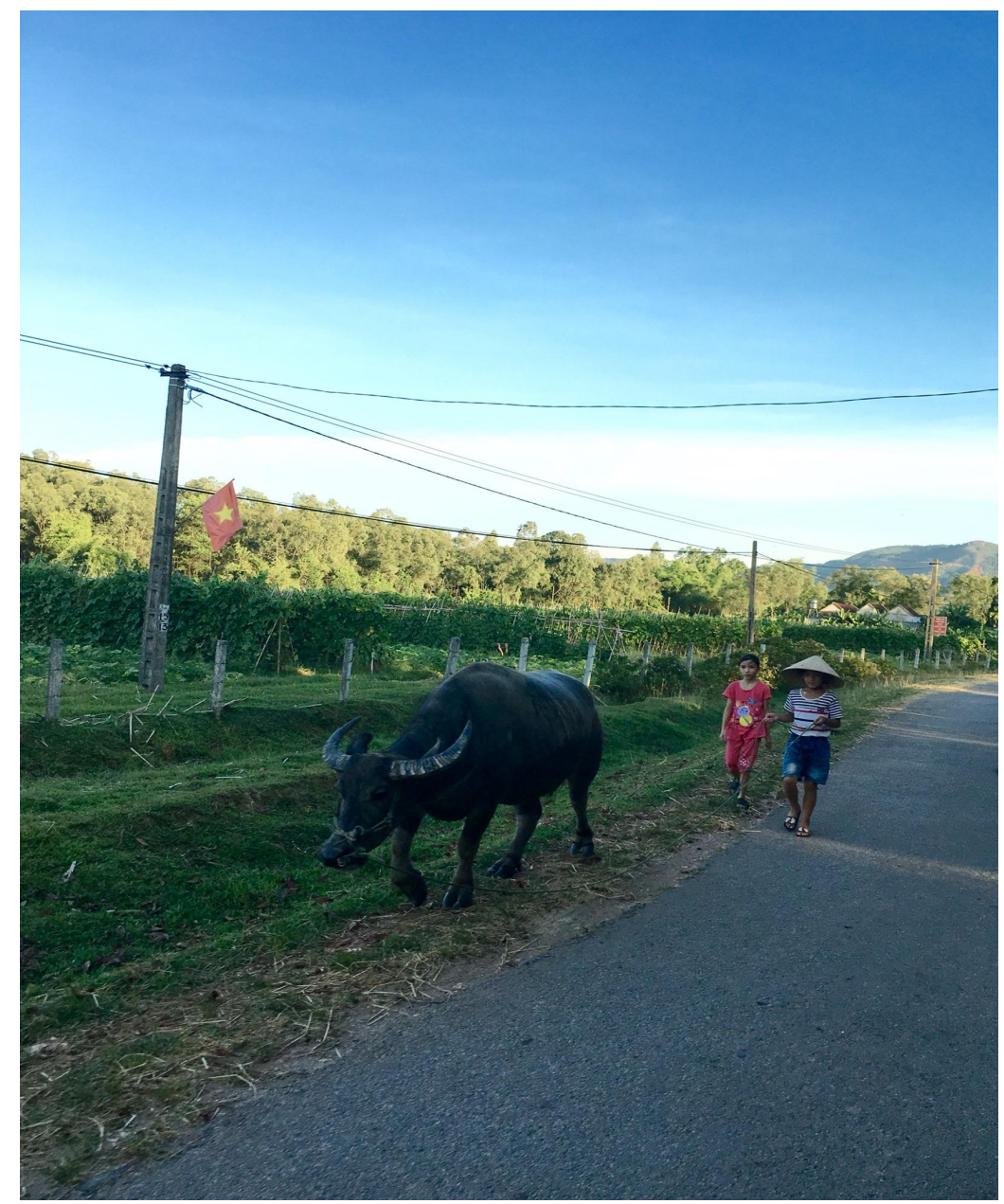

Photo taken by author during field work, June 2016. 
Due to the intense workload on the farm and the involvement of the children from an early age in family labour, most of the parents whom I talked to showed themselves to be understanding about the results of their children's study. Very few of the parents interviewed specifically put pressure on their children to perform well at school. The fact that many rural parents compromise their children's study due to busy farm work may enable the young generation to be quite flexible with their study - they can either finish their basic education or quit early to work if they wish. Most of the youth in this area would normally have their basic education at home and then face a choice between either moving to a new place to find a non-agricultural job or staying home and helping with family farm work. Not all of them wait to finish high school, and not all of those who stay until high school aim for higher education like colleges or universities. Moving to other cities or provinces to work in economic zones for factories or in other lowskilled jobs has been the more popular choice for most of the young people in this region rather than working in the farming sector. Due to the lack of jobs, it is typical for young people to leave their family to either study or work elsewhere, then later reside in the cities or other regions where they could earn more stable incomes. As a result, I noticed that the majority of workers who had remained in the rural hometown are seniors or those who have married, had children and settled their family in the villages.

\subsubsection{Keeping a low-profile life - how people make irregular migration work}

Despite some of the benefits to be gained from irregular migration in terms of flexibility and income, migrating illegally for work carries a number of risks. In this section I explore the impact of those risks on migrant workers, and the steps they take to reduce their vulnerability. In the view of several migrant workers, they risk exposure to the local authority in two ways: one is when they are out and about in public and might be ID-checked by the police, and the other is when the police arrive on the spot at their workplace. In fact, it has been found that not only are the migrant workers whom I interviewed highly sensitive to their illegal status, but so too are their employers fully aware of the risks associated with hiring illegal workers. Often both parties reach a mutual understanding whereby a very low profile is maintained for the migrant workers, especially at work. In 
some cases, as I was told by my informants, employers bribe the local police to go easy on their employees, and may bail employees out if arrested by the police. However, this case cannot be generalized for all employers in destination countries.

There are other cases, as I was told by the research participants, when employers take advantage of their workers' illegal status to exploit their labour. Informant 15, for example, went to Thailand to work 12 years ago in 2004. When she first got to Thailand, her employment was arranged by a broker who was paid to transport her to work as a kitchenhand for a Thai employer. The employer did not pay her the agreed salary for the first three months she was there. Informant 15 had to tell her broker to arrange for her to work at another place. She recalled: "They kept promising that they would pay me, and after three months without payment, I was mad so I quit. I moved to another place. When I decided to move to another place, they didn't let me go. They told me to go home and they would send me the money, but they didn't". Informant 15 migrated irregularly with the help of a broker from the same village but who now resides in Thailand, returning to the village occasionally to "recruit" workers to Thailand.

When asked about support in dealing with unfair treatment as well as other work-related issues, the informant said that she did not rely on any other source of support apart from her broker who lived in her area. She did not know the Thai language and therefore had to rely on the only contact she knew - her broker to communicate her concerns to her employer; when the conflict resulted in her leaving her job, she had to rely on him to arrange for new work placement. She knew other Vietnamese irregular migrant workers in nearby areas who might have been in similar situations to herself. Both the broker and she decided not to confront the local employer, afraid that the employer would call the police and report on her illegal working experience. She recalled:

"I lost my salary. The old employer didn't know where I moved to next. I didn't argue with them, because if I do, they will call the police to arrest me. If the police got me, I will be in trouble. When I said "trouble", I don't mean like being beaten up or anything, but they would arrest me and keep me, then I won't be able to work, I won't have money" (Informant 15) 
As discussed by Caouette et al. (2006), irregular migrants have few, if any channels through which to seek redress when they suffer abuse, and they do not dare protest against not being paid or not being paid in full, not receiving wages on time, or for physical and sexual abuse. None of my research participants had experienced physical or sexual abuse. While there was unfair treatment and verbal threatening as shared by informant 15, other migrants shared that their employers were very nice to them (Informants 03,05). However, it seemed there were few channels for them to seek justice, given their awareness of the illegality of their work. Many of the migrants interviewed said they could rely on the brokers who had transported them to the destination, who knew the local language, and had established networks to arrange for new work placements in case of unfair treatment. None had reported unfair treatment to any support channels due to the fear of deportation (Field notes, 2016). The story of informant 15 is only one among many similarly exploitative incidents that irregular migrants face in their everyday lives in foreign lands. This reflects the fickle labour relations between different ends of the working relationship that, at any stage, can turn migrant workers into victims of exploitation and mistreatment. In their illegal working experience, the irregular migrants I talked to were found to be heavily reliant on a fragile relationship with their broker who had brought them to the foreign land, and their employers who provided them with jobs. Such work is arranged in an environment where the labour commitment is based on verbal agreements alone, and the working experience of the migrant workers is dependent on their luck in having a decent employer, and in not being exposed to any local authority.

This study found that the participating irregular migrant workers had no formal access to social services. In addition to having very basic living conditions, most of the migrant workers bear in their everyday life the fear of being reported and arrested by the local police. As a result of working illegally, all the migrant workers interviewed in this study limited their outings in public and chose to take good care of themselves to ensure their ability to work, self-medicating when sick to minimize access to any social services in destination countries. Their lives involved going to work, coming home to rest at night and then going to work 
again the next morning. Some of the female informants who were live-in maids stayed indoors most of the time, constantly aiming to avoid detection by the local authority. According to some of my informants, if caught by the police they faced detainment in a police camp for several months until they had enough money to buy themselves a plane ticket home, while their deportment would obviously be recorded by the police.

In sum, irregular migration on the one hand has proved itself to be a possible means of sustaining lives in rural areas for local people; on the other hand, this type of livelihood diversification brings with it the everyday uncertainty that can put every migrant (and every member of their household involved) at risk. Since the nature of work in the irregular migration process is illegal, most of the migrants do not rely on any legal protection. They also avoided confronting employers in any case of mistreatment or exploitation since they can use the local police as a powerful force to the irregular migrant workers' disadvantage. The irregular workers, therefore, are precariously situated in the receiving society with the possibility of exploitation without legal protection. This may explain the fact that not all people in rural areas are likely to choose irregular migration. Every irregular migrant worker is a risk-taker, since the work in the foreign land is largely unknown, and life in the foreign land is unlikely to be pleasant.

\subsection{Why irregular migration?}

\subsubsection{The differences between regular and irregular labour migration}

This research finds that there are several differences between regular and irregular international labour migration that make it the choice for some, but not for all. First of all, regular labour migration has certain criteria for migrants to meet. For example, one has to go through vocational and language training before they are fully admitted to the labour exchange programme. The training period depends on each programme and the ability of each participant, however, it normally takes from three months or six months to a year. The trainees often have to take a test to pass the training course and then move on with the programme. Once fully admitted and sent to the foreign labour market, labourers are contracted to work for their employers for a certain amount of time (Dang et al., 2003). The Ha Tinh Department of Labour, Invalids and Social Affairs (DOLISA) 
is the governmental authority at the provincial level that regulates and manages the implementation of labour exports in the province, in accordance with national law. One of their functions is to publicize Vietnamese policies and laws about workers working abroad under official labour contracts (Ha Tinh DOLISA, 2016b). Figure 7, for example, is an official brochure issued by the Department about a joint labour export programme between Vietnam and South Korea, to be distributed and promoted to citizens in the province. According to the brochure, the contract time within this official labour export programme is three years, with conditions for possible extension. The deposit fee (or bond) is regulated at 100,000,000 Vietnam Dong (approximately 4,500 USD) for the South Korean market, and which labourers are required to deposit prior to departure. The deposit will be deducted as a fine if migrant workers break the labour contract. The deposit will be transferred back to the migrant workers upon their fulfilment of the labour export programme contract. 
Figure 7: Ha Tinh's DOLISA brochure on the joint labour export programme between Vietnam and South Korea

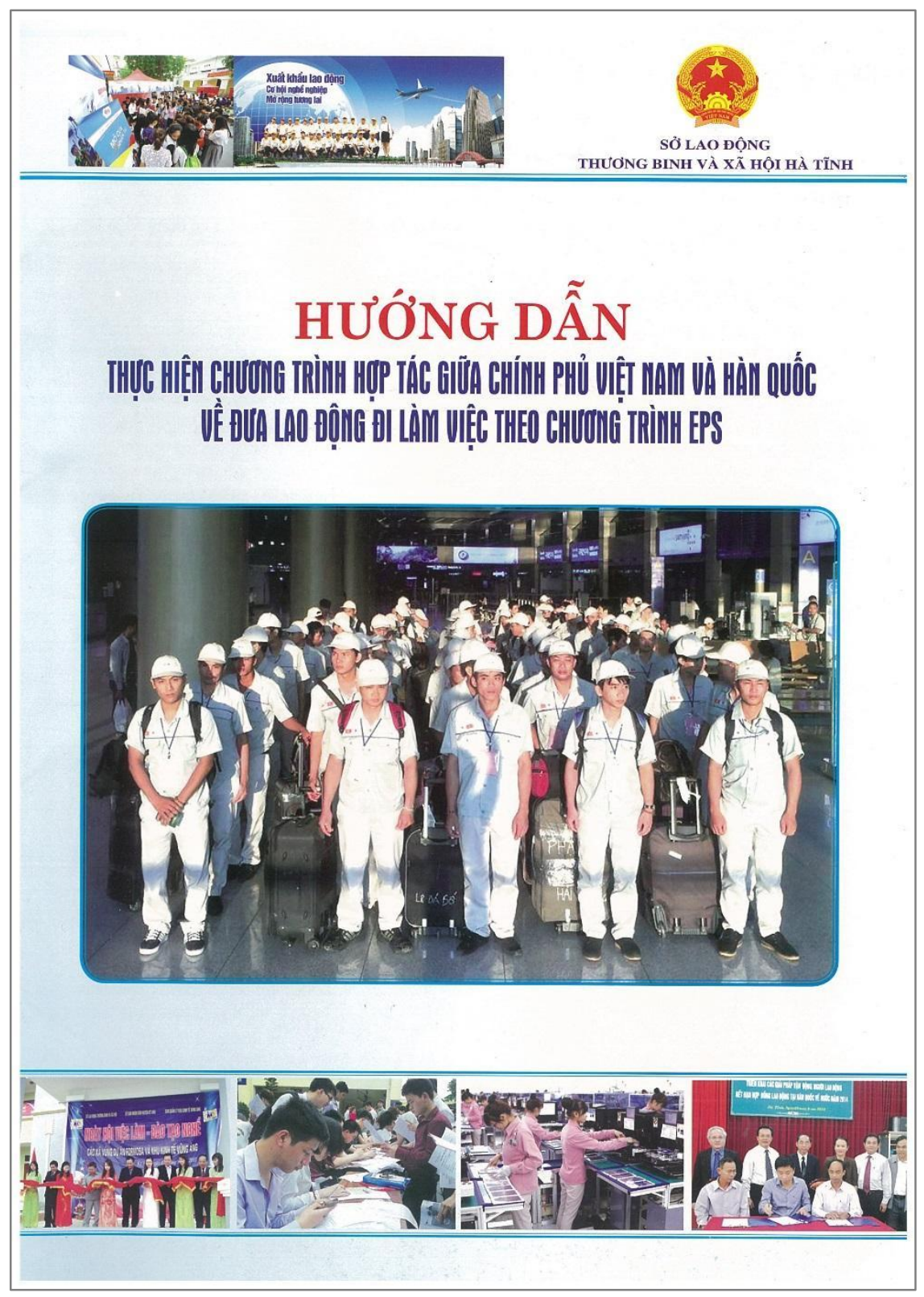

Source: Ha Tinh DOLISA, retrieved by author during fieldwork, 2016.

Besides factors such as the time for training and preparation prior to departure, and all the costs associated with regular migration, the labour export programme also regulates certain age limits and health requirements. These requirements are very transparent and accessible to most labourers since they are published on the website of many recruitment companies, as well as provided in the official brochures. The information is also provided through the offices of various labour export agencies in the province. Labourers from 18 to 32 or 35 years of age and 
in good health are eligible. Some particular fields that require labourers with good industrial skills such as garment-processing and electrical welding can intake labourers of up to 39 years of age. This information was found by a simple Google search on the internet and extracted from three websites of private agencies promoting labour export to South Korea, Japan and Taiwan ${ }^{10}$.

The fee associated with regular labour export (which must be paid by migrants prior to entering their training) consists of various fees including the training fee, air ticket, and labour export service fee (Informant 16). According to Ha Tinh DOLISA, besides the deposit of 4,500 USD, the fee for a labourer to join the programme in South Korea is 1,250 USD including air ticket, training fee, insurance and other expenses. This amount is considered rather high for rural people, so many of them never consider this type of regular migration as an option for their livelihood diversification. In contrast to the cost of regular migration, irregular labour migration is much cheaper. An informant shared that it cost her a total of 250 USD to have a broker take her to Thailand and find her a work placement (Informant 08).

In general, it is acknowledged that regular labour migration calls for strict requirements that a labourer has to meet in order to work overseas, while irregular migration, presents itself as a very flexible option. Irregular labour migration has no age limit or specific health requirement, requires no training of skills and language, and, in most cases, costs migrants significantly less than regular labour migration. With regular migration applying strict rules and requirements, even some of the local people whose families could afford the higher cost of regular migration were not able to meet the criteria. A migrant worker shared: "I didn't meet the health requirement for Malaysia so I couldn't go. So I decided to go to China [irregularly]" (Informant 12). Low cost and flexibility made irregular migration an attractive way to work overseas and earn better money. More than one of the informants in this research commented that upon making their decision, they could call a broker to arrange to migrate irregularly. The broker would collect enough people to go on one trip and inform

\footnotetext{
${ }^{10}$ The websites were: http://vieclamhanquoc.vn/xuat-khau-lao-dong-han-quoc-yeu-cau-nhungdieu-kien-gi-64.htm; http://xuatkhaulaodongnb.com/dieu-kien-de-duoc-di-xuat-khau-lao-dongtai-nhat-ban.html; http://vieclamdailoan.vn/dieu-kien-di-xuat-khau-lao-dong-dai-loan-210.htm
} 
them of the departure day within a short period of time (Informants 03 and 11). It can be seen that irregular migration is quite flexible and requires very few procedures from the migrants' end.

Even though irregular migration emerged in rural area as a feasible option for local people's livelihood diversification, the major difference between the two kinds of labour migration discussed in this section rests with the illegality of the irregular migration process. This factor is the biggest challenge that irregular migrant workers face in the making of their everyday lives in destination countries. Due to the illegality, most of the migrant workers maintain a very low, almost invisible profile in the receiving society. Pham and Hill (2008) discuss the importance of retaining a rural foothold in the hometown along with other structural factors, such as legal barriers and a lack of social support, all of which make it difficult for rural migrants to fully integrate into their new urban social settings. The situation for irregular migrants is very different. All the irregular migrant workers interviewed were found to be aware of their illegal working status, and, in response, improvised and adopted their own strategies to avoid social integration into their receiving communities. With that being said, the irregular migrant workers willingly and intentionally chose their roles as the "passer-by" in the new society in order to minimize, at least from their end, any chance their illegal working scheme might be sabotaged. In that way, the migrants were able to work and maintain a regular flow of income to serve their migratory purposes. For the irregular migrant workers, retaining their foothold in the rural area became the way they held onto their original identities. It indeed strengthens their sense of belonging and acts as a spiritual reminder of where their real society lies.

\subsection{Decision-making}

\subsubsection{The poverty push and the economic development pull}

The previous section explored the differences between regular and irregular labour migration. It was followed by the analysis of the migrants' characteristics and their migratory purposes based on age groups. The discussion below builds on these two sections and identifies further the reason why research participants chose irregular migration as a livelihood strategy. This, I believe, will give us a 
richer understanding of why irregular migration fits into the livelihood diversification of certain people in the rural area.

The majority of irregular migrant workers interviewed in this study went to nearby countries such as Laos and Thailand via road routes. There were two participants who went to further destinations, two to Angola, and two to China. As mentioned in the literature review, migration can be explained through certain push and pull factors that impel people to move from their countries of origin to reside in certain destinations. This section will attempt to locate irregular migration from Ha Tinh under the influence of push and pull factors. From the perspective of the irregular migrant workers interviewed in this study, low living conditions and limited job opportunities contributed much to outmigration in this region, while the better economic opportunities and the need for labour in receiving destinations attracted them to new places. A push and pull diagram of irregular economic migration is presented in Figure 8 to visualize the migratory decision process of the irregular migrant workers in Ha Tinh.

Figure 8: The push and pull diagram of irregular migration

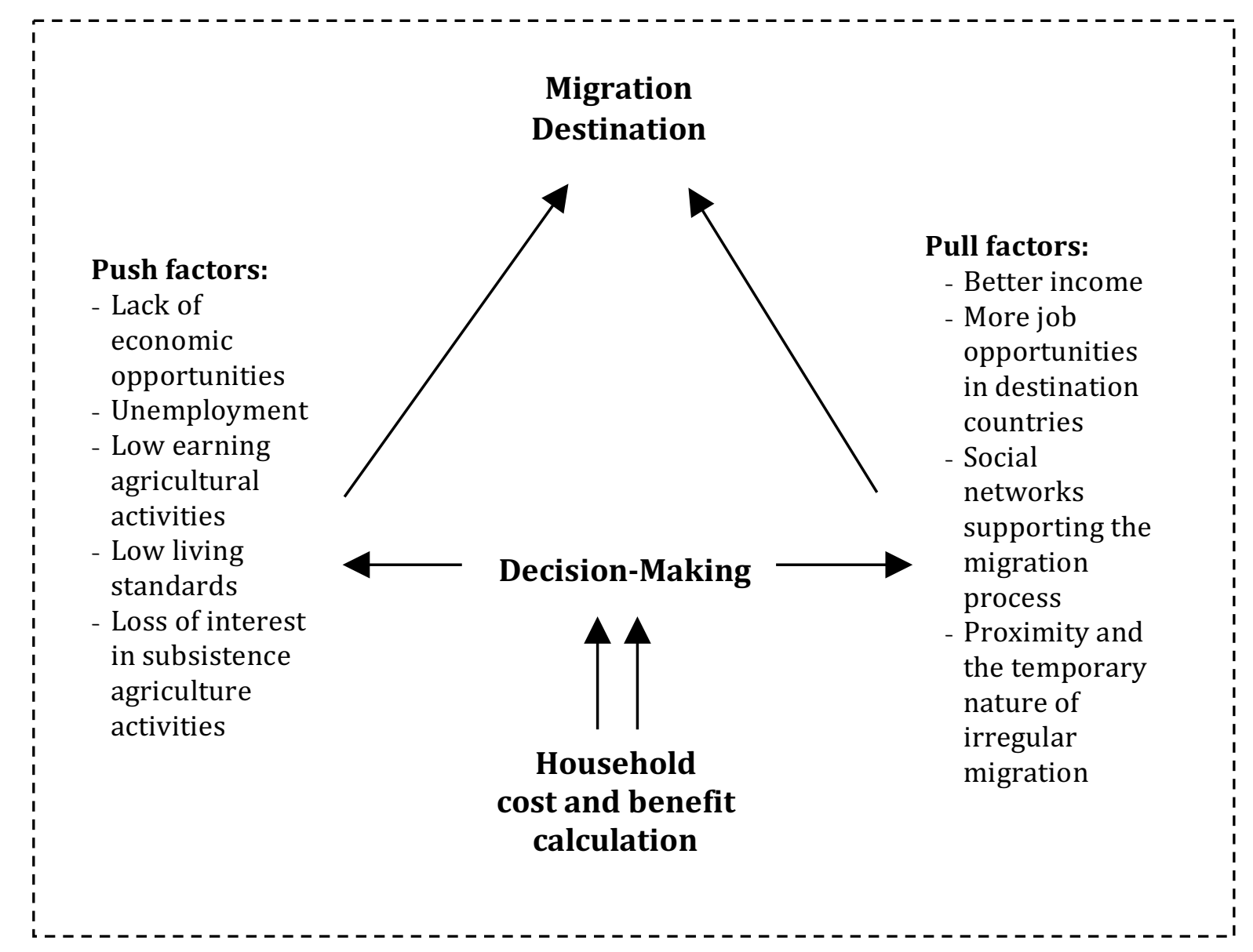


Figure 8 illustrates a simple model of irregular migration that I generated from the responses of the research participants. This model locates irregular migration under the push and pull framework of migration, as predicted through the theory of the New Economics of Labour Migration (NELM). According to Figure 8, the decision-making process of the participating irregular migrant workers was strongly influenced by structural push and pull factors in the sending and receiving destinations. However, the decision-making was never a linear process, it was in fact governed by a detailed set of household cost and benefit calculation. For the sake of illustration, the detailed list of the household cost and benefit calculation is presented in a table in the following section. Figure 8 shows that push and pull factors are primarily macro and structural, and exist at both ends of the migratory process. In order to turn ideas into action, local people conduct a thorough cost and benefit calculation including risk assessment between the options of going away irregularly or remaining at home. With the main 'push and pull' factors being structural, these factors are quite set and immobile while decision-making based on the household's cost and benefit analysis consists of more personal, household-specific reasoning (See Table 4). In a detailed manner the migrant workers made their irregular economic decisions based on considerations around the cost of the migratory process, how much one could earn and save monthly, and how long one required to save the amount of money which the family had set out to earn. A detailed description of the cost and benefit analysis is generated from the responses of the research informants and presented in Table 4 below. 
Table 4: The household cost and benefit analysis

\begin{tabular}{ll}
\hline Challenges at home & Benefits of migrating \\
\hline - Hard, low-earning farm work & - Stable job with higher monthly \\
- Poor living conditions & income \\
- Few much savings & Being able to save most of the \\
- Struggle to afford nutritious food, & salary since food and \\
clothing and tuition fees for & accommodation are often provided \\
children in school; would become & for the migrant workers \\
harder as they entered senior or & - Being able to afford education for \\
higher education & the children \\
- Minimal improvements to the & - Having more financial support for \\
house & family living conditions and \\
- Have to borrow money in the & improvement \\
village in case of emergency or on & - Faster rate of debt repayment \\
special occasions, such as sickness, & \\
house improvement, buying a new & \\
tool for the farm & \\
- Slow rate of debt repayment &
\end{tabular}

\section{Benefits of remaining home}

- Being close to family and being able to share household responsibility between husband and wife

- Being around for the children's upbringing and guidance and taking care of elderly family members

- A more comfortable social life surrounded with family and friends

\section{Challenges in destination countries}

- Being far away from family

- Differences in language and culture

- More pressure and workload for family members left behind

- Illegal work

- Minimal social interaction

- Minimal living conditions

- The stress of maintaining a low profile in the foreign land

\section{Factors of consideration}

- Social network: Acquaintances or relatives working in the destination market and their irregular migratory "success stories"

- The cost of migration

- The income in destination markets

- Debt repayment period once they have worked overseas

- The change of roles in the family and division of labour

Source: Author generated from views shared by research informants (2016). 


\subsubsection{Financial matters}

Most of the participants decided to migrate (illegally) based on a family's cost and benefit analysis in regards to economic outcome, and on thinking about their future prospects. According to most of the research participants, life at home was hard and their economic situation was not promising (Field notes, 2016). For them, staying at home meant sticking with farm work, which consisted of mundane tasks from around the house to the paddy fields. A view shared among research informants was that farm work did not bring much profit to the family economic situation. Much literature about Ha Tinh points to the region's harsh climate, unfavourable soil quality and limited irrigation systems as major factors in the province's low agriculture and aquaculture productivity (Ha Tinh E-Portal, 2016; World Bank, 2004). This has been validated through many of the research informants' remarks. On one hand, farmers would have to work hard all day to maintain subsistence level agricultural activities. The hard work, on the other hand, does not reward them with sufficient crops and income for the family. For the particular informants of this study, rice is the dominant crop of cultivation, with other agricultural activities being seasonal vegetable- and fruit-planting, and livestock husbandry. For example, Figure 9 shows a field of cassava and sweet potatoes which were widely seen in all the villages during fieldwork.

"At home I only worked on the farm, I didn't have anything much. Seeing other people around here going to work overseas and making better money than at home, I decided to go too. Farm work at home didn't earn much, life was hard" (Informant 03).

"Currently at home, with the severe weather, low salary, hard work and not much working time - in a year, you would only able to farm for five or six months, so the income is not stable. It's a vicious circle" (Informant 04). 
Figure 9: Sweet potatoes and cassava field

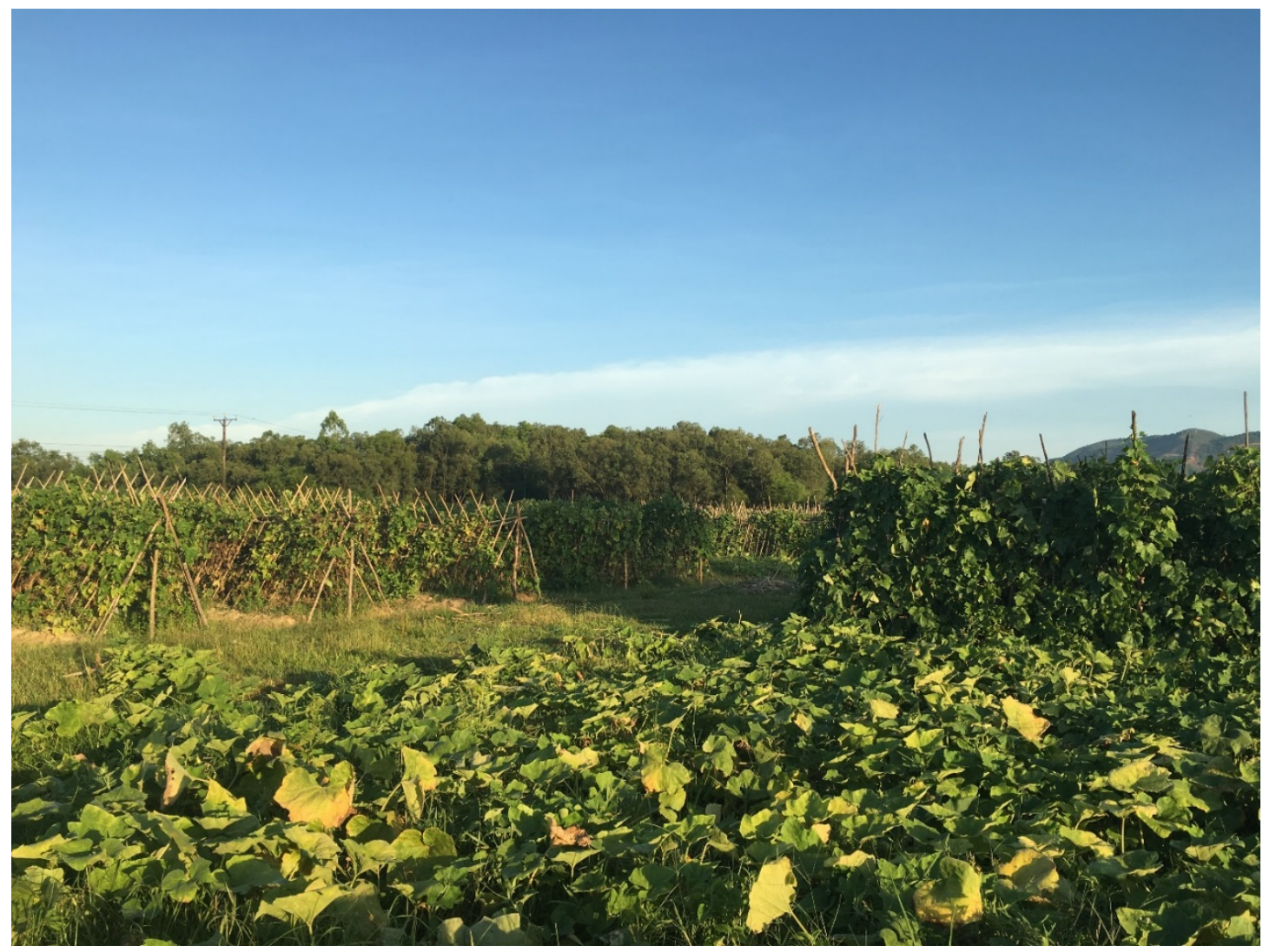

Photo taken by author during field work, 2016

Even though remaining at home is hard on the economic side, as the irregular migrants have stressed it, home was still the comfort zone for most in terms of social and spiritual aspects. As one participant has commented: "Staying at home is good in many ways, but the money earned is less. It is very comfortable at home with the family and the kids, working in Thailand you have to follow the schedule, work and finish according to time, at home you take a break whenever you want to." From this comment, it can be seen that the migrant workers have decided to trade their comfort at home for the economic outcome of their migratory experience in order to improve their livelihoods. As a result, they can have jobs with stable incomes to serve their financial purpose. A common view among the illegal migrant workers interviewed for this study was that it was not difficult to find jobs in the destination markets. There were usually "more job opportunities than at home" (Informant 02), and the fact that all of the irregular migrant workers were able to find jobs easily in the destination countries confirms this view. 
"All you need is health when working overseas, they would employ you no matter if you're young or old, just as long as you're healthy. They'd take you even if you're disabled, for example if you have squinty eyes, not like other countries where they would not hire you. Even in Vietnam they would not hire you. There, they even hire people who are one-armed or one-legged. It was easy to find jobs there" (Informant 05).

It is a common practice in rural Vietnam for poor households to be dependent on networks, family and friends to cope with financial shocks during hard times. Borrowing money is a popular and almost unavoidable way of circulating money in times of need and when the rural family is short of savings. Barslund and Tarp (2008) have found that relying on informal as well as formal loan sectors is very common in rural Vietnam. According to these authors, two of the formal lending institutions in the Vietnam rural credit market are the Vietnam Bank for Agriculture and Rural Development (VBARD) and the Vietnam Bank for the Poor (VBP), while the informal sector can be categorized into two groups of private lending by (i) unrelated individuals and friends charging interest and (ii) by family, relatives and friends charging zero interest. Collateral is associated with all formal loans while no collateral is needed in the informal sector. The formal sector mainly deals with demand for production loans and asset accumulation, for example when a rural family wants to expand their farming land or invest in new agricultural diversification activities; while most of the loans from the informal sector are used for health expenditure and consumption (Barslund \& Tarp, 2008). This reflects the opinions shared among the research participants. Most confirmed the existence of provincial agricultural financial support programmes in the area that lend farmers funds to invest in farming and agricultural diversification activities. However it would take a long period of time for farmers to make enough profit to pay the debt, while they still have to cover the monthly interest (Informant 07). As one informant said: "At home we can still borrow money from the government, however there were so many difficulties in life, we'd still have to borrow here to afford there, there was not much circulation, and we'd still have to worry about paying the interest every month" (Informant $04)$. 
The formal loan system is the choice of farmers who are interested in expanding their agricultural production and farming system; often these farmers are those who choose to stick with farm work and invest most of their effort and resources in their farming activities (Field notes, 2016) (See Figure 10). On the other hand, other families, who do not plan on farming expansion, would maintain their existing farming assets and send one or more of their family members to work in a non-farm sector somewhere else to diversify the family income. They often access credit through the informal loaning system. Almost all the research informants in this study mentioned that it is common for them to borrow money from local money lenders in their village (Informant 02, 04, 05, 07, 11.1). And while the formal loan systems require much paperwork and the collateral, the informal credit systems in the countryside run smoothly and at people's convenience, and require no collateral.

Borrowers from the informal sector have the option of paying a monthly interest rate and paying the original debt amount at the end of the debt period, or accumulating the interest rate (if any) and paying altogether with the debt at the end (Barslund \& Tarp, 2008). The informal loan sector, therefore, has always been an easier way for rural people to access quick credit. They borrow money from the informal sector and, when they cannot repay their loan, their debt has accumulated to the point that they face the pressure to earn money for the debt repayment. According to a migrant worker:

"The whole village here, everybody has to borrow money from people. Some people who do not have the ability to make profit they don't dare to borrow money because of the interest rate. Other people who want to build the house, they would borrow the money. If you want to do some business, you will need from four to fifty million VND, you would have to borrow. Where else do they get the money? It is hard here. They just have to pay the debt gradually, work hard and cover the debt monthly and make ends meet dayby-day like that" (Informant 07).

It was usually when they were under pressure to earn money to cover their debt, or aimed to invest in family improvement, that local people looked at irregular migration as their best option (Field notes, 2016). 
Figure 10: A small farm of pigs and chickens established by the loan from the local financial support programme
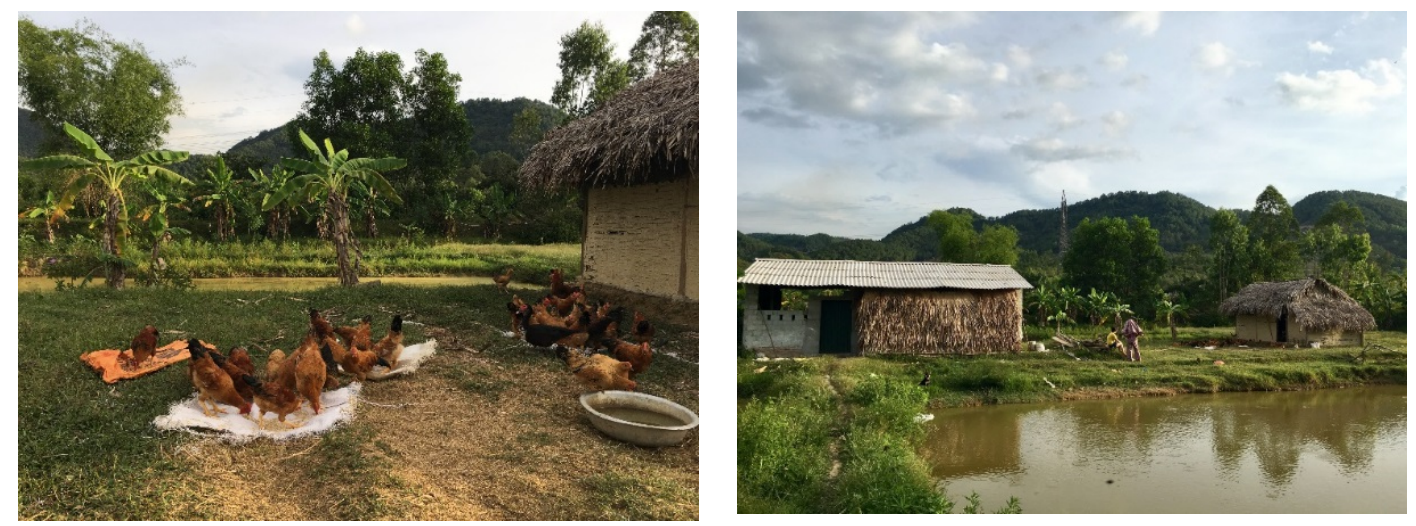

Source: Photo taken by author during fieldwork, 2016

For many local people who have gone overseas to work through the official labour export channel, money spent on regular labour migration was considered an investment by the migrant family because the cost was very high by rural standards (Informant 07). Many of the migrants had to borrow money to work overseas, with the hope that the money they saved from the salary could cover the initial investment, sparing them the extra for family improvement. However, there have been cases where regular migration was not as profitable as expected. A regular migrant worker who went to Malaysia shared:

"I paid 27 million VND [1,300 USD] to the labour export company to go to Malaysia, my salary was around six to seven million VND a month [300 - 350 USD]. The job itself was so much, it was hard work, and every day we exhausted ourselves. I worked in a factory that produces spare parts for washing machines and phone screens. We had to stand all day. After a year I thought that the money wasn't worth for what the job was, and they were very exploitative to us workers, they didn't treat us well, I think labour export agency should not recruit Vietnamese workers to work in Malaysia anymore. It was so hard and the treatment was very bad." (Informant 07)

This informant also said, "If I could choose again, I would definitely go to Thailand to work like many neighbours around me [irregular migration]." (Informant 07) The mother of an irregular migrant worker told me how quick and easy the informal loan system was in the countryside. Informant 11 , in his early 20 s, was 
thinking about going to work overseas for a while before he had the courage to tell his mother. On the morning when he told his mother about his wish to go to China, his mother did not have the financial support he needed to be able to go. The cost for him to go to China with a local broker was seven million VND [350 USD]. During lunch break, his mother managed to have the money ready for her son. She recalled: "One day, he decided to go and told me in the morning. We didn't have money for him to go, so I had to borrow money in the afternoon that day. I told him I had borrowed the money for him, and that later he would have to send the money home to pay back that amount. Then he was gone, it was $2 \mathrm{pm}$. That was last year." (Informant 11.1).

While the official labour migration cost was too high, resulting in a prolong period of repayment for the borrowed money invested in migration, irregular migration costs less, meaning that the migrant workers will be able to pay their debts faster and accumulate capital more quickly. Comparing irregular migration with farming, the informants commented that irregular migration would help them earn a stable income every month, while farming was weather dependant and required farmers to invest significant labour and resources over a long period of time to make profits. While farm work did not provide farmers with exceptional financial income, irregular migration has become a more appealing option, especially when migrants can see for themselves that several generations of irregular migrant workers have returned home and shown how their life has changed after the experience:

"It is of course more profitable working overseas than working at home. Working at home, you only work for six months, and you've earned some amount of rice. But working overseas you get paid every month, like me, I've earned five to seven million [250 - 350 USD] a month. Eating and accommodation was provided, phone call and daily expense was not much, with that salary I was able to send money home. I made enough. I really want to go for another trip, but the opportunity hasn't come." (Informant 06) 
"It is harder with agricultural work at home. I worked on the farm in Vietnam for six months and earned as much as I could earn in a month working in Laos" (Informant 02).

In light of the findings of this research, I feel the need to use the term "irregular economic migration". Irregular migration in this research was found to be purely for the purpose of economic betterment. Even for some younger migrants, whose reason for leaving the village was due to boredom in the countryside, were fully aware of the risk of working illegally in a foreign destination. Therefore they only migrated to earn money (Field notes, 2016). Through observations and interviews, this research found that remittances were expected by the local people to be the most significant outcome of the migration process.

"The first time I left the house to go [to Thailand to work illegally], I was very nervous. Then I remembered a talk with my friends when we told each other: "think of the money then you can do it!" I went abroad to work for the money, so I just thought of that to go." (Informant 06, female)

My research participants on the whole reflected that while subsistence agriculture in the villages could only help farmers make ends meet, other responsibilities and basic needs such as healthcare, children's education, and household improvements required farmers to invest. The majority of migrant workers who had children of school age said that one of the main reasons they worked overseas was to earn money for their children to go to school, because “you can't afford your kids' education with farm work” (Informants 02, 04, 05, 06, 15). Even though the purposes for irregular migration vary between different informants, the bottom line for most of them was that staying at home with farm work does not offer the surplus income to spend on other necessities of life, let alone family improvements such as building or renovating houses or simply buying a new TV or motorbike.

Initially, informant 11's wish to work overseas was not approved by his parents. According to his mother, the parents were concerned about the destination their son planned to go to. As she said: "We heard much around and on TV about human trafficking in China, and other harmful things in China". Despite his parent's wish 
for him to stay home, informant 11 decided to migrate anyway. He worked in China for ten months and was able to remit home. When he got home after the first migration, his parents were more assured about his migration since he was able to accumulate financial capital and he was safe (Informant 11.1). Due to his previous migratory experience, the second time informant 11 asked to go to China, his parents "didn't have to think too much". His mother recalled: "Since he had been there and was able to earn income, we didn't think too much, we felt more assured the second time he went" (Informant 11.1). Apparently, the economic outcome of migration plays an important role in the decision-making of the migrant family.

\subsubsection{Social network}

This research finds that irregular migratory decisions were made based on thorough discussions among family members, however the idea was initiated in most cases would be the one who wanted to migrate irregularly (Informants 04, 06). As one informant said: "because it was me who would go work there, I brought up the idea. I thought a lot about how the family would be without me. My husband assured me, he said if I wanted to go then I should go and not worry about things at home" (Informant 06). Before the decision was made, the family of the migrant worker conducted an internal "inventory" of the family's financial and economic situation, envisioning a thorough division of responsibilities and labour in the household in the case of one migrating. They also considered other irregular migrants' experiences and their economic betterment in their decisionmaking. The migrant worker migrated knowing that there was a plan of farm and household labour division and parental roles for those who stayed behind.

From the starting point of looking inward to evaluate their household situation, the migrant's family began to look outward at their neighbours and community to gain more insights. Among research participants, many shared the view that their decision was made partly by looking at other neighbours' positive experience with irregular migration. Many of the informants mentioned that seeing their neighbours go abroad and make profits made them want to do the same (Informants 03, 05, 06, 02, 13, 14). One said "My friends have gone before me, I consulted with them and they suggested I go too" (Informant 04). Another 
worker said: "I thought our economic situation was difficult, when I saw other people return home from working overseas, I decided to go" (Informant 03).

Most of the migrant workers relied on the experiences of friends or relatives who had migrated irregularly to make up for their uncertainty about working illegally in a foreign market (Field notes, 2016). In making their decision to migrate, the irregular migrant workers had all consulted with family and friends who had migrated before them. They responded to their network's previous experience to compensate for their lack of understanding about destination labour markets. The network is of utmost importance in shaping the choice of destination for most migrants: since they could only imagine how life in the foreign land would be, they relied greatly on the sharing of their networks, and in most cases picked destinations that their contacts had been to previously so they could refer to those experiences. This explains why the migrant workers responded to a certain job market instead of others. When asked why she picked Thailand instead of another labour market in the country, one migrant worker said: "I didn't go work in other provinces [in Vietnam] because I didn't know anyone there, but my friends asked if I want to go work in Thailand [with them], so I went". From my observation during interviews, even though rural people knew there might be consequences for their illegal work, most set out to work overseas with hope for the outcome of their migration. The role of their network was essential in consolidating their decision - as one of my female informants said "If they can do it, we can do it too!" (Informant 05).

The importance of networks in motivating irregular migration can be further explored through the story of Informant 04 below: 
Informant 04 , in his early 40 s, just got back home in the village two days before we had a chance to meet in June 2016. He migrated to Angola with the help of a friend who also worked in Angola. Before his migration, he had never thought of working overseas, because he only knew labour migration through official channels which costs so much that he could never afford it with farm work. The chance of irregular migration was offered to him by his friend who mentioned this idea and even offered to lend him the money needed. Informant 04 described this opportunity as "an investment" in that his friend invested in him. Before the migration, the informant and his family were working on the farm and struggling to pay a debt of about 3,000 USD. After he consulted with his friend, informant 04 discussed the opportunity with his wife and decided to go. The friend lent him 5,000 USD and he chipped in another 2,500 USD to go to Angola. Every month he was able to save 1,000 USD to remit home. Informant 04 worked for a Chinese construction contractor when he first arrived in Angola.

Being very proactive in Angola, the informant quickly learnt the language and understood how the business worked. He moved out on his own after a while and became a small contractor himself with a small group of workers that used to be his colleagues. In Angola, informant 04 paid a local man on a monthly basis to be his guarantee contact; as he said: "I paid the guy around 200 USD a month and he would guarantee for me, he would tell the police that I work for him then I should be fine. But only during work time, I work from 7-11am, and 2-5pm, so during this time if the police came, this guy would guarantee for me. Any matter outside that timeframe, like troubles when you go out and drink, robbery and things like that, they are not responsible for us". Informant 04 was arrested several times during his four years working in Angola, and lost around 6-7,000 USD for the fines he paid to the police. However, he was very confident about the economic outcome of his migration.

Informant 04 came back home to take care of his sick father, and was staying home to observe the Angola market as the Angola kwanza was depreciating in comparison with the US dollar. He said he would migrate irregularly again after some time, either to Angola if the value of the kwanza increased, or to another market, confident in his ability to learn the new language and adapt to life in the destination country.

Interviewed 16 June 2016

The story above indicates the strong role of social networks in shaping migratory decisions. As mentioned in the previous section, the cost of migration plays an important role in decision-making, given the low earning situations of most would-be migrants. However, as can be seen here, cost is not necessarily the most important factor. In the case of informant 04 , the cost of migration was 7,500 USD, which is even higher than a regular labour export programme to Malaysia or South Korea. Nonetheless he went to Angola, under the influence of his social network. Despite the implication that the friend encouraged him to go in order to expand his own network of Vietnamese workers in Angola, the informant also 
benefited from having a friend as his contact in the destination country. His decision to go was also based on a thorough consideration of many other cases. He commented:

"Life was very hard for us then, our family was struggling. The kids were small and we were in debt, one crop after another. My wife was very concerned when we first discussed this idea, because I was the head of the household, if I was away, my wife and children will be struggling. I told my wife not to worry, that we should believe in our decision for the future, and that it will be fine if I go. I was able to send 1,000 USD home only a week after I left Vietnam, because my skills were very good. I was better than most other workers. Among ten workers I was better than nine and a half of them".

It is worth noting in this case that informant 04's family had a strong response to the high financial return from his migration. Even though the cost of his migration was rather higher, they were able to pay off their debt faster; as informant 04 said: "The money I earned was ten times bigger than at home, we paid our debt, life got better from there".

The findings from this research also suggest that the migrant workers who go further afield are those who are more courageous and more proactive (Field notes, 2016). Moreover, gender relations also played a significant role in the choice of destinations for the migrants. Most female migrants, as described in section 2.5.2, have a strong feeling for their responsibilities as the caretakers and mothers in their families, so they tend to migrate to nearer destinations in order to come back home when necessary. Male migrants, on the other hand, considered as bread-winners, can be freer to travel to destinations further afield to earn incomes. Often the further destinations compensate the migrant workers with better salaries, however, those who went to further lands faced more risks in terms of health, and from the different climates, working conditions, security, culture and environments (Informant 04,13). For example, migrant workers who went to Angola were exposed to severe weather and a high chance of malaria. It is also harder for migrant workers in more distant places to go home, due to both the distance and the high cost of the air ticket. However, it can be seen that the higher rates of return drive the more self-motivated towards it. Some of the 
informants specifically showed their confidence in the job markets of destination countries, especially when they had acquainted themselves with the new environments and living situations. They felt they could get a new job easily if they didn't want to work where they were previously employed. The more experienced the migrants became, the more comfortable they were about their illegal working status (Field notes, 2016).

\subsubsection{Proximity and the precariousness of irregular migration}

This study finds that the majority of research participants chose their destinations based on the distance between the country of work and home. For that reason, Thailand and Laos were the most popular choices, but further destinations were also migrated to. Since the irregular migrants were aware of the temporality of working illegally in a foreign land, they tried to minimize the risk for themselves and their family members by choosing a nearby market: as one informant said, for example, "if there's anything at home, or my health is not up for the job, I have to go home. That's why I decided to go to Laos because it's closer to home" (Informant 02). As Pham and Hill (2008) have discussed, the distance between the destination and home, and the cost associated with migration, are two significant factors in shaping the decision to migrate. The closer the destination, the easier the decision to migrate. Proximity in this case can also be considered a strategic calculation for the family; as many migrants and their families shared with me, the relatively small distance allowed migrants to return home fairly easily in case of an emergency at home. (Field notes, 2016). In this case study, while there were migrants more likely to respond to the high rates of return available in more distant lands, for most migrant workers the proximity between their work and home was an important factor of consideration.

Through consultation with other irregular migrant workers who had been working overseas and shared their experience, most of the informants appeared to be aware of the risks, and did not commonly aim to earn money to the extent of becoming wealthy (Field notes, 2016). To my understanding, there was a certain level of satisfaction identified and agreed upon by the family prior to migration, thus migrants only set out to earn enough to serve their family 
purposes. "To be better off, but not to be rich" as many commented. Once irregular migrant workers had accumulated or remitted the expected amount of money to achieve their goals, they normally returned home to focus on farm development or the family business using the capital acquired after their migratory trips. When asked why she had moved back home, one migrant worker said: “My family was able to afford when I don't work there [Thailand] anymore so I went back and decided not to continue" (Informant 03). In all cases, the irregular migrants were aware of the risks posed by their overseas illegal working experience, however their worries and fears were eased by the knowledge that their irregular migration was also temporary. As discussed in Chapter Two, Belanger, Ueno, Hong and Ochiai (2011) discuss the precariousness of irregular labour migration in a way that explains why so many labourers in Japan choose to quit their regular labour export programmes for irregular migration, in this study of irregular economic migration from Ha Tinh, a similar finding was confirmed.

"We thought a lot about it. Of course when life is hard and we didn't have enough, we have to consider about it, we discussed a lot before my wife went. Because the work is illegal, we had many concerns. However, it was lucky because the time my wife went was not too long. The money earned was not much to compare, but it was better than earning at home. At home, we work so hard but we didn't earn much." (Informant 6.1, family member of an irregular migrant worker)

\subsection{Summary}

This research finds that irregular economic migration is increasingly becoming the choice of livelihood betterment for many in rural Ha Tinh. This type of temporary migration has only drawn much attention recently due to the noticeably increasing flow of local people crossing international borders despite the risks of working illegally and living vulnerable lives in foreign countries. The findings presented in this chapter portray irregular migration as a choice of livelihood strategy for the rural population in Ha Tinh, as many other types of regular migration are. That said, irregular migration has become more popular due to its flexibility and low cost. However, it does not eliminate or replace other 
types of migration from the region, more likely it serves as another feasible option for the economic betterment for local people who reside in the countryside. There are certain features of irregular migration that make it the right choice for some, but not for all. There are certain groups of people who are more likely to respond to irregular migration than others. Additionally, the findings show that the more self-motivated a migrant worker is, the more successful their migratory experience is, with outcomes being translated into an improvement in living conditions. As much as irregular economic migration is becoming a popular choice of livelihood strategy, it also carries with it the vulnerability of its irregularity. The findings in this chapter bring the perceptions of the insiders to light; hopefully it has unpacked the layers of complexity involved in the evolution of irregular labour migration in the rural area. Understanding how irregular migration has been adopted as a way to sustain rural livelihoods, and the range of reasons why local people engaged with it, will be useful to better appreciate the development impacts of the migration process. These will be discussed in the following Chapter Six. 
This page is intentionally left blank 


\section{Chapter 6: The development impacts of irregular labour migration}

\subsection{Introduction}

As discussed in previous chapters, the type of labour migration studied in this research is specifically identified as "irregular economic migration" since the migratory aims are mainly for economic gains. This chapter addresses the third research question of the study in regards to the development impacts of irregular labour migration on migrant workers, their family members and the community. Even though such migration is related to economic betterment, its impacts affect the community, the workers and their families on a wide range of economic and social aspects. The first section of the chapter explores economic impacts and the second discusses social impacts.

\subsection{Economic impacts}

\subsubsection{The remittances}

Since irregular migration has, in the previous chapter, been identified as a household strategy to cope with livelihood shocks, the economic impacts of the migration are therefore observed on a household level that includes impacts on migrant workers and their family members.

Generally speaking, remittances - the direct economic impact of irregular migration, no matter how big or small - were acknowledged by the majority of research informants. To many, the migration is quantified by the number of trips taken. The economic outcome in some cases is associated with individual trips. No specific timeframe is set to a trip: some migrate for years, while others take shorter trips within a couple of months, depending on the "workload in the destinations" (Informant 02) and personal family matters (Informant 04, 05, 06. 11). For people who had migrated far from home, such as Angola, the trips taken by migrants would normally be longer than those who migrated to nearby lands (Field notes, 2016). There were two participants in this research who went to Angola for up to five years; during this time they only went home once. As 
discussed in Chapter Five, working in further labour markets is compensated by higher salary rates. An irregular migrant in Angola commented:

"A month, I work 15 to 20 days, excluding my daily expense, I was still able to save about 1,000 USD to send home. It was around twenty something million Vietnam Dong, that was good don't you think? After a year and a half, I was able to send home to my wife around 15 to 16 thousand USD" (Informant 04).

For those who went to nearby countries, the closer proximity allowed them the flexibility to migrate for some period of time, return home for family business and migrate for another trip. This flexibility was traded off by a lower rate of salary. Across the participating migrants who went to nearby destinations, the current monthly remittances varied from VND 5 million [USD 250] to VND 7 million [USD 350] depending on their jobs and experience. A female migrant commented: "With my salary, it was not much to live there [Thailand], but that same amount made life easier in Vietnam. It was much better than doing farm work" (Informant 05). The comment reinforces the findings in the previous chapter that the majority of migrant workers respond to better pay in destination countries for similar jobs to those available at home. Once again, the pattern of push and pull in migration studies was observed. The migration habits of those from this area of Ha Tinh are shaped by their response to the potential for better economic development in destination countries.

In 2015, the average income of salaried workers in the Vietnamese agricultural sector was reportedly VND 4.5 million [USD 225] (GSO, 2015). The monthly earnings of irregular migrant workers in foreign countries is higher or similar to the standard incomes of regular salaried workers in the agricultural sector in Vietnam. When they can save and remit most of their income back home, the amount of money was considered more than sufficient for sustaining rural livelihoods.

The economic outcomes of irregular migration are directly connected with the worker's ability to pay their debts. Through irregular migration, local people were able to obtain financial assets to cover their family debts. As reiterated by a 
female migrant: "Because we were lacking so much, we had to borrow money. That was why I decided to go work overseas. We were in debt so I had to go to earn money. During the time I was away we didn't borrow more money" (Informant 09). In this light, the burden of financial debts were lifted through irregular migration, as further confirmed by another migrant: "When I went abroad for work, the money I earned were ten times bigger, we paid our debts, life got better from there. If I was home, we would only make enou8gh to maintain our simple life, the debts would still be hanging there, life was improved when I went abroad" (Informant 04)

\subsubsection{Household improvement}

Housing improvement was a common purpose for many wanting to earn money through irregular migration. Many of the participating migrant workers reported that their remittances were used to build or renovate their housing (Informant 02, 06, 08, 09 and 11). Some participating migrants also commented that by "seeing people in the village going away and coming back with the ability to build their houses" (Informant 05, 08), they were inspired to do the same. When asked about some of the changes in her household after her migration, one irregular migrant shared:

"There is much change: all the houses we built with the money I earned. The first trip, when I came back we built the main house. The second trip we were able to build the back house. The third trip, we were able to build the husking machine workshop on the side" (Informant 06).

Informant 06 has been an irregular migrant worker in Thailand for three years since 2013 , the first time working on a dog farm for five months, the second as a caretaker for seniors for nine months, and most recently as a kitchenhand and waiting tables at a cafeteria for a year. She went back to Vietnam to help her husband attend to family business and was hoping to migrate again. She said: "I need to stay home now, but if opportunity arises, and my husband let me, I would go again". Her husband and she were content with the earnings from the rice husking business they set up after her third migration, however she remarked that "it is not as much as working in Thailand". 
During fieldwork, my interviews with participants were conducted in their homes. To my observation, all the participating migrants had renovated their houses to some extent: there were two storey houses with tiled polished walls, single storey houses being strengthened, expanded and newly painted, and homes decorated with good quality wooden furniture. Some households had big screen TVs, and some migrants reported buying new motorbikes.

Figure 11: A house being built in the village

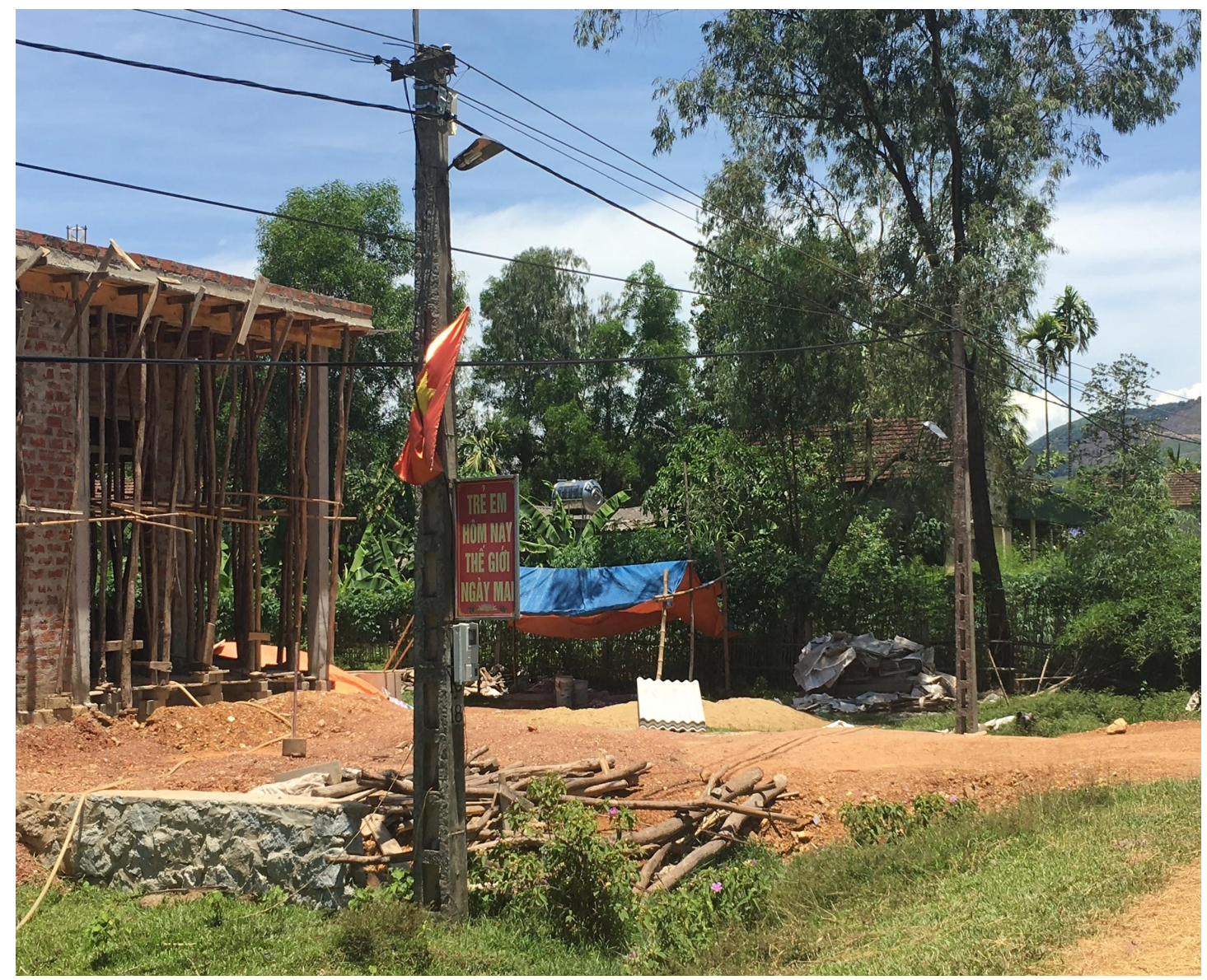

Photo taken by author during field work in June 2016.

Figure 11 above captured a house under construction in one of the villages. The most common housing in the village, through my observation, are the one storey houses built with bricks and cement on a higher ground (to avoid flooding in the rainy season) with several rooms of different size connected to each other. This basic type of brick structure was an upgrade from the traditional houses of bamboo and earthen walls which were popular in the rural area 15 to 20 years ago. Some of these traditional houses with earthen walls were still spotted in the 
villages when some families had renovated their main houses, but their back houses and the kitchens remain fairly simple (Field notes, 2016). The basic one storey houses were designed to allow homeowners to upgrade their houses further when they could afford. I noticed a variety of housing structures ranging from the simple houses with cottage roofs, to the popular one storey brick houses with a flat roof, to two storey houses with decorations, a garden of bonsai and painted high metal gates for protection. One of my participants told me: "If you look around the village and see newly-renovated houses or two storey houses, those families definitely have people working abroad, the houses were all built with the money sent home from migrant workers" (personal communication, June 2016).

\subsubsection{The accumulation of economic capital and a more dynamic local economy for the community}

Conducting interviews with the migrant workers at their own places allowed me to observe their living conditions. I was able to see with my own eyes some of the visible outcomes of migration. As well as housing renovation, outcomes were also visible through the accumulation of household assets: "in terms of daily life, we have food and we could afford more facilities in the house, it has been much better" (Informant 04). Expensive items such as motorbikes, new big screen TVs or wooden furniture suites were observed in the houses of the migrant workers. These assets along with the improvement in housing conditions showcased the practical economic impacts of irregular migration, not only tangible within each migrant household but also visible to local people and the community. Furthermore, their presence allowed people in the community to draw their own comparison between life before and after migration and how it not only sustains but also transforms rural livelihoods for those involved.

The housing improvements were not only positive for migrant workers' families, but also transform the rural villages themselves in terms of infrastructure, economic and social development. On a community level, there was reportedly more renovated housing, better roads and drainage systems. On a household level, in my observation toiletry conditions seem to have improved, while many other households in the villages still practise open defecation. A non-migrant local villager has said to me: "If we have money, we would have to focus on our 
children's study first, then fix our main house, so the building of a toilet will have to wait" (personal communication, June 2016). Obviously, due to the lack of economic capital, the local people have to set priorities for their spending and a toilet is often the last thing on their list. Fortunately, through irregular migration, many local households were able to afford better hygiene and sanitation and improved living conditions by renovating their houses.

Besides its positive impacts on the village infrastructure as well as on the living conditions of local people, irregular migration also makes a significant contribution to the local economy. Firstly, with the growing number of irregular migrant workers, the villages experienced a stronger flow of purchase in the field of construction materials, electrical goods and motorbikes as remittances were reportedly spent on construction and assets accumulation. Secondly, and on a smaller scale, irregular migrants said that the money they earned help their families buy food and groceries on a daily basis without having to be indebted to the sellers. In this sense, irregular migration improved household consumption and supported a more stable flow of cash income for local farmers in the market. Lastly, irregular migration helped create seasonal jobs for workers who reside at their place of origin. Obviously there was a scarcity of labour in the community when many local people had migrated. However, with the remittances the migrants sent home, their families were able to hire labour in the villages to help with their farm work. Additionally, the hiring of labour to help with construction work in the villages, given the increase of housing improvement, as another economic outcome of migration is also worth mentioning. It is safe to say that irregular migration has changed much of the scenario in the community of migrant workers. Its economic outcomes were visible for the families of migrant and their community. Through migration, migrant workers have provided their families with financial security, accumulated economic capital, improved their living conditions and contributed to the development of the community. These positive benefits of migration are important for the family and the community in sustaining their daily lives and evidently providing them with a stronger capacity to cope with shocks to rural livelihoods. 


\subsection{Children's education as social upward mobility for future generations}

Education for their children was cited by many participating migrant workers when asked why they had migrated (Informants 02, 04, 05, 14, and 15). As a result, the educational outcome of the children was acknowledged. For example, a migrant worker in Thailand commented:

"There is not much change in my household, but I was able to raise my kids and afford for their life and study. All those years I was away, with my earnings I was able to afford the education for my children, one went to college and one has finished high school" (Informant 05).

Another senior female migrant to Thailand shared:

"I was working in Thailand for ten years to earn money for my three children to attend university. I come home once or twice every year but I was there continuously for ten years until all my children graduated. Now I'm happily back home, and my children were able to support me now that they have university degree and have jobs" (Informant 15).

The aspiration of the parents for their children to attend higher education and to have a better future were lively throughout the interviews with different participating migrants. A migrant worker in Angola shared:

"My children are still small, they always want me home to be with them, they'd feel more secure when I'm home. However, little do they know that I went abroad to gain them a better future. Later if they want to study high, we would have the money to afford their education. We would not be able to cover for that tuition fee if I was still home" (Informant 04).

When asked about the achievements after her migration, informant 05 paused for a while. I could see the signs of sadness etched on her face, as she was probably recalling the time she was in Thailand. She later said:

"For those who went to Taiwan or other countries, or other regions of Thailand where you can make great profit, I don't know how they make much money, there were people who are really better, but for me, going 
there was just enough for my kids to go to school, it was hard still" (Informant 05).

Education is believed to be a 'way out' of rural poverty. Even though the expression among participating migrants varied, it was clear to me that there was an association between education and social upward mobility. The parents interviewed in this research expressed their desire for the children to participate in non-farm careers, and, through the education they could afford after migration, they believe that their children are more likely to secure formal employment in the private or public sector. Looking at this from the sustainable livelihood perspective, education demonstrates a household strategy to achieve better opportunities and to obtain a higher social status with better livelihood outcomes. The human capital created through education in the long-term is also a more sustainable way to cope with the risks of livelihood shocks, given farming in Ha Tinh is at risk from the effects of severe weather and seasonal natural disasters.

\subsection{Social impacts}

\subsubsection{The family calculated livelihood strategy}

Many rural migration studies have discussed the case of both parents migrating for work, leaving their children at home with their grandparents. This is typical in many cases of rural-urban migration in Vietnam, and a similar pattern of both migrant parents leaving their children with grandparents has also been discussed in the case of irregular migration in Myanmar by Set Aung (2009). Interestingly, the participants in this research set up a different arrangement. Except for one case of a female widower who had to leave her two daughters to her father and later her brother while she was away working, most of the migrant families with children in this study have arranged for one parent to migrate, and one parent to stay at home to take care of the family. This reflects the approach that local people have adopted to sustain their lives and at the same time maintain their family dynamic and bond. Through this approach, families of migrant workers will be able to enjoy the fruitful impacts of their migration as a whole and find ways to overcome livelihood shocks truly in keeping with the family calculated strategy. 


\subsubsection{The agency of the self-motivated irregular migrant workers}

Besides its economic outcomes that make people "see us differently" as worded by a male migrant, what irregular migration offered to the migrant workers is the feeling of confidence in the original community: "we were more confident as well, much more" (Informant 04). He further iterated:

“On a general basis, there are many changes. We didn't have much before. From little things like going to the market and buy some vegetables or meat, they would not let us take the food and pay later, they would not let us borrow and owe them money. After I was gone, they'd let us borrow. It was simple like that, there are changes" (Informant 04).

According to the migrant workers whom I interviewed, they did not use any money transfer services. Their remittances were often sent home through their acquaintances or the brokers who had returned home to recruit more workers, and therefore the money was often accumulated and transferred whenever there were people travelling back home (Field notes, 2016). Since the migrant workers and their families had no control over the regular flow of remittances, the families left behind still had to rely on borrowing to maintain their daily lives or in cases of emergency. However, their ability to repay debts upon the receipt of remittances ensured smooth access to fast and easy financial credits. As mentioned in the previous chapter, local people are often dependant on the informal loan system through the act of borrowing to spend on some important expenses or basically to subsist on a daily basis. In this case, it can be understood that irregular migration was used by migrants and their families at home as a guarantee for their loans no matter how big or small. It also represents the ability to repay debt by the migrant workers' families. Most of the time, the informal loan system in the countryside runs on a trust basis since the collateral is not compulsory. When the borrowers have the ability to pay part of their debt according to the mutually agreed repayment schedule, the lenders trust that their loans will be returned. There is some flexibility in terms of repayment deadlines based on the way remittances were transferred from migrant workers to families. There were cases when migrant workers had returned home and were still waiting for their salaries to be liquidated (Informant 02, 04). The lenders were 
found to be aware of this fact but, so long as there was guarantee of payment, they would have no problems with late payment (Field notes, 2016).

In sum, irregular migration has not only brought about positive changes in the families of migrant workers and their community, it also has empowered them and, in a way, transformed their level of agency. Irregular migrant workers were reportedly more confident and knowledgeable after going through irregular migration. One expressed more confidence in earning financial capitals for his family:

"This time, the currency crisis in Angola has made earning money harder, but I don't worry too much. If we were in debt for 20 to 30 million VND [700-900 USD], I would not have to worry about the payment at all. Before, with that amount of debt, we would be so worried, we would not know where we could make extra money to cover for it. Now, it's so much different, once I went abroad, things changed and I want to continue going abroad to work" (Informant 04)

Others commented that they now "know better" about life in destination countries:

“At the beginning, I was very worried. I didn't know their language so I was nervous, like even if they were mad at me and scolded at me, I didn't even know how to respond. Now it will be easier. Now I can communicate, I can ask for food if I'm hungry and understand the basic language, my employers were very happy with me. They really trusted me. I really want to go there again" (Informant 06)

The feeling of confidence and the knowledge that the migrant workers obtained through their irregular migration suggests that their empirical human capital has been accumulated through their experience working overseas. This type of human asset can give the participating migrants an advantage in their strategic pursuit of livelihood betterment. Through the interviews, many of the migrant workers said that they also shared what they knew about the migration process with their neighbours and acquaintances. The sharing reflects the indirect benefits of irregular migration as it has become the means by which migrant 
workers strengthen their social networks and empower others who wish to follow their footsteps in improving their rural livelihoods. Field research shows that often those who expressed a more enthusiastic attitude towards their migration outcomes, as quoted above, are those who were more self-motivated. They are more proactive and more able to adjust to the new life in the foreign land. Their migratory outcomes were, therefore, more explicitly acknowledged. The difference in how each migrant worker addressed their economic outcome is believed to have a connection with their satisfaction with their migration. The more proactive and self-motivated migrant workers were, the more adaptive they became in their illegal migration experience, which in turn, resulted in their rather more positive view of outcomes (Informants 02, 04, 06, and 5). On the other hand, others seemed less fortunate with their irregular migration, and expressed lower levels of enthusiasm over the results of their migration. For example, box 2 below is a story told by a female migrant in Thailand who was not as "successful", as she worded it. She decided to return home shortly after her migration, afraid she would be caught by local police and worried about her illegal work.

\section{Box 2: Story of a migrant worker - Informant 10}

I have four children, and I decided to go to Thailand to earn some money so my children can go to school. I didn't expect to be back after five months.

I wasn't accustomed to the work. I was also worried, I thought if something might have happened to the guy who took me there, I would be in trouble. I wouldn't know how to get back home, I would die there, and I was worried because I didn't know their language. My Vietnamese friends who also went to Thailand, they'd call me and ask where I was, I didn't know where I was, because I didn't know the language, I had never been overseas, I mostly stayed inside the house.

On one hand, I was afraid of being caught by the police, on the other hand, my salary was low. I stayed with the mother but I had to work for both of her daughters, it was a lot, and the salary was low, so I decided to go back home. I called the guy who took me there and told him to take me home. When I was travelling home, I was scared. I had to take the boat along the Mekong river. It was a small boat with 12 people on it. It was an automated boat, but at the beginning we had to paddle manually. They only started the engine once they got further out. They were afraid that the police would notice and arrest us all.

I'd had enough with it, even if you give me money, I wouldn't go again. In the village, we have many people who went to Thailand for work. There are many people who are so better off after they have worked overseas. I don't know why I was not. It was horrible when I went. I think I'm not destined to be rich. Mentioning Thailand now scares me.

Source: Interview of Informant 10 
In another case, portrayed in box 3, the migrant worker was exploited and bullied by her employers. Since she did not know how to get home on her own, she had to rely on a group of Vietnamese migrants for help.

\section{Box 3: Story of a migrant worker - Informant 08}

I worked for this employer for two years. I had to do night shift, I cooked sticky rice, fried up spring rolls. I did a lot of things for the shop. They open at $5 \mathrm{am}$, they sell food to the monks, and then I fried spring rolls and helped them sell food. I normally finished at 8 or $9 \mathrm{pm}$. At $9-10 \mathrm{pm}$ when they came back home I had to clean, put left-over in the fridge and clean everything, after that I went to bed, but I couldn't sleep because I had to wake up early in the next morning.

I was there for two years and then I wanted to quit but they didn't let me. I cried a lot, I asked them to let me go. They said they would tell the police to arrest me. I said I'd rather be arrested by the police so I can be sent home.

After two years they didn't let me go, they even threatened to beat me and throw me to the Mekong river. They threatened me. We lived near the Mekong river, the water was very high. I kept saying that I would go out there for the police to arrest me, so I can be home. Then they let me go, after two years of constant hard work, waking up at $1 \mathrm{am}$ in the morning and working till late at night.

When I left they gave me 1,000 USD to go home. I didn't know Thai money, they didn't know Vietnamese money. I didn't know many Vietnamese, they didn't let me go outside to know other Vietnamese. They only kept me inside. So when I insisted on going home, they sent me to their younger sister's place so the sister could arrange for me to go home through Laos. She lives near the border between Thailand and Laos. Her husband buys coffee from Laos. My passport didn't have visa stamps, so they were thinking to ask this guy to help me go through the borders. They kept me there working for them for another four months because they were short on people. The younger sister paid me 1,200,000 VND a month [60 USD].

I was there for a couple of months, they didn't let me go either.

One night I was working, sitting in front of the shop, and I saw a group of people whom I guessed were Vietnamese. I ran to them, asked them where they were from. They said they were from Thach Luu, then I asked if they knew where people from Quy Hai stayed (her home commune). They said they know a lot of people from Quy Hai residing in one place. They asked if I want them to take me there then they would take me there on Sunday. But I said I couldn't go because then I would be in trouble, I asked them to take a letter to those Quy Hai people.

Then I wrote a message through them, I wrote something like "Please anyone come help me to go home, I have been here for two years, it is so tough here, they don't let me go, I don't know where this is, please come here and tell them whatever, like my mother has passed away, or my house has collapsed, whatever, so they'd let me go!". So the people from my village came to that shop to find me, the boss didn't let them in, they were afraid of losing their stuff from strange people stealing, but I told them these people were my villagers, they said my house had collapsed so please just let me go home. I was away for two years and my documents didn't get stamped, the boss said if I go home and get arrested, they would not be responsible. The villagers knew, so they said they would 
guarantee for me. They said they would take care of it, and be responsible for me so the boss just let me go. Then they agreed to let me go home.

They were mean, on the day I left, they called the police on these people. I was lucky I got home because if they arrest me, I'd be imprisoned and had to lose all my savings to pay for the fine. But these people were arrested by the police, they came at their rental place and caught them all.

So I was home after two years with 12 million VND [600 USD]. And it was so miserable.

Source: Interview with Informant 08

It could be seen clearly from the stories of informant 08 and 10 that their situations were more fragile than others, possibly because they were less selfmotivated (as described earlier to be less proactive, not as able, and not knowing the language). The case of informant 08 also reinforces discussion from Chapter Five exploring how migrant workers' social networks encourage the flow of migrants. The story told by informant 08 shows how the social networks, not necessarily of people who know each other, but of irregular migrants of similar origin who were in similar illegal situations, have been set up like a support system. In this case, the social network can not only inspire other people in the community of origin but also support others in case of unfair treatment in destination countries.

Two stories told by two older female migrant workers show that the experience of migrants is very diverse. Apparently, these two informants were not as "successful" with their migration as other informants. From here, I contend that even though there is evidence to say that irregular migration transformed the agency of migrant workers, this only applies to certain migrant workers who are evidently more self-motivated than others.

\subsubsection{Irregular migration and gender relations}

\subsubsection{Irregular migration and gender relations: Findings through interviews}

This research finds that the participating migrant workers responded to gendered labour divisions in the labour markets. I interviewed more female migrants than male migrants. As discussed in section 2.5.2, the research includes one case of female negotiated migration (Informant 06), while the rest of the married female migrant workers were found to have consensus prior to their 
migration (Field notes, 2016). Hoang (2011) indicated that these four patterns are a simplification of reality and there are, in practice, some continuities and some cases that 'fit' each pattern better than others. Indeed, one participating migrant was a widower, and she therefore (reportedly) made the decision to migrate on her own (Informant 05). Her decision was by chance, but not by choice, categorized as an uncontested migratory decision.

Interestingly, the response to gender roles in occupations in the receiving destination resulted in changes in the migrants' own household labour divisions, as well as perceptions about gender roles in their places of origin. During their migration, females' roles in the family were found to be left in the hands of their partners or relatives who remained at home. For most families of female migrants, husbands reportedly took on housework tasks such as cooking and taking care of the children at home while their wives worked overseas. Women reportedly had more power in deciding their migration; most women interviewed said that they initiated their decision to migrate before mutual discussion with partners. Female migrants also received acknowledgement from husbands for achieving the desired economic outcomes of migration and their roles in the family (Informant 6.1). The husbands were more open to being in charge of domestic tasks and to allowing women to both take more initiative and have more say in the family business. Female migrant workers were more empowered through their contribution to the family economic improvement, sharing that they become more confident and "feel that I have the rights with the money I've earned" (Informants 06, 05). The wives of male migrants were also more engaged and assumed more responsibility in the household during their husbands' migration (Informant 4.1). The interviews showed there was more autonomy for the women who stayed behind in regards to contributing their opinions in the decision-making process for both the household and the farming business. No significant change in the role of the head of the household was observed, however, as most husbands and wives agreed that the head of the household remained the husband. In this regard, a female irregular migrant explained: 
"Always my husband is the head of the household, he is important in the decision-making. If he agrees, then I can go, he is superior, he is the head, I'm a woman, I put him first. I only work, but all the decisions I follow him." (Informant 06)

In the past few years, with the booming development of technology, the internet and generations of smartphones have considerably changed how people connect socially in rural Vietnam. Thanks to the internet and mobile connections in the rural Ha Tinh, most migrant workers were able to connect with their family on a daily basis. According to a male migrant, regular contact with his family at home helped him retain his position as the head of the household. He said:

"I still am the head of the household and my wife is my main support. She'd work harder to take care of the family when I'm gone, but all decisions were made with my consultation. It was not difficult to contact each other thanks to the internet. Nowadays it has been easier. Before when I first got there, I had to call home because I only had a simple phone. When things got improved, we were able to afford better smartphones and we were able to connect even cheaper than before with internet calls. The cost for internet top up is not much, and it allows us to connect all the time, we could talk all day until we don't want to talk anymore"

He elaborated further:

"We agree on things through communication. We were able to contact each other through wifi connection, my wife would call me when there's anything at home. We talked to each other twice a day, so we were able to consult with each other on decisions. It was so easy because of the wireless internet, we were able to talk and see each other's face" (Informant 04).

\subsubsection{Irregular migration and the ability to negotiate: how gender and rural livelihoods are reconstructed through migration}

Much research has explained the rise of low-paid and low-skilled female migrant workers to make up for a lack of native women in female dominated employment sectors such as care service, health and domestic work, since women in receiving regions have become reluctant to work in these sectors (Ehrenreich \& 
Hochschild, 2002 cited in Hofmann \& Buckley, 2013). This has been confirmed through this case study, in that participating female migrants were found to be predominantly working in the low-paid service and domestic sectors.

This research has also found that Vietnamese rural society has undergone a shift in social beliefs about gender in relation to irregular migration and livelihood betterment. However, this shift is negotiated for the economic outcomes of migration, and such social change is easier to accept in the rural context of this case study due to the temporary feature of irregular economic migration. Evidently, the fact that globalization has crafted more economic opportunities for women, and that living conditions have not much been improved in their places of origin, has gradually influenced more women to migrate. In the case of a temporary, irregular migration as studied in this research, the findings specifically show that rural people have become more flexible and open to the idea of female migration. The short-term nature of labour migration enabled female migrant workers to still attend to their family responsibilities when necessary. The female migrants in this study were generally found to migrate for a shorter period of time in comparison with their male counterparts; even for female migrants who spent many years working overseas, they had managed to visit home at least once a year to make up for the time being away from their families (Field notes, 2016). This can be considered as a way of negotiating their gendered role and responsibilities in the family. By having the shorter period of migration, the women have made it easier for their partners to adapt to any change in gender relations as a consequence of their migrating (Informant 6.1). On another hand, the women interviewed also expressed a strong connection with their identity as mothers (Informants $03,05,06,07,14$, and 15 ), they were also therefore more at ease with the fact that their time away from their children was only temporary and, ultimately, for the better life of their children.

Across the range of fieldwork in four different villages in Ha Tinh, the general feedback from local people towards irregular labour migration was the acknowledgement of the migrant households' economic achievements (Field notes, 2016). Men are found to receive more respect from other men in the community for their migration and women are being more accepted for their 
absence from home (Field notes, 2016). Unlike other cases of contested masculinity for the men who stayed behind and took on the role of their migrated wives, as Hoang (2011) has identified, the husbands of the female migrants in this research expressed very positive attitudes towards the migration of their partners. The community, from my observation, has also become more open and less judgemental in the cases of men who stay at home. No husbands were found to be ridiculed by neighbours about the fact that they stayed back while their wives migrated (Field notes, 2016). In addition to the community being more open to irregular economic migration, the men who stayed at home still maintained farm work and the role of the head of the household. In this vein, masculinity has been reconstructed to fit in with the new way of sustaining rural livelihoods.

The signs of a change in gender relations, and the fact that the role of the women in the household have been better acknowledged, are positive signals for a more balanced gendered relationship in the family, as well as recognition of increasing gender equality in rural areas. However, it has been clear to me that there are limits to the empowerment that the participating female migrants experienced through irregular migration. While the female migrants and the wives of the male migrants were shown to be more confident, taking on more household responsibility and contributing more to the household decision-making, their roles as women, wives and mothers still constrained their full participation in irregular migration. Women were found to feel more confident with their economic gains, however, they were still bounded by the beliefs of a gendered, traditional role for women; thus they tended to put their husbands and children as their first priority and had to find ways to balance any gendered tensions in their family by compromising their migratory time (Field notes, 2016).

In conclusion, there were changes in gender relations in regards to irregular economic migration. However, the changes were being negotiated by both sides of the relationship thanks to the precariousness of irregular migration. Both men and women have experienced the change in their perceptions towards gender relations, however, the ultimately gendered features remain unchanged. Men have been more flexible, but remain as the heads of the household. Women have 
gained more autonomy and confidence thanks to their economic achievement, however, were still confined by the gender norms and relations of traditional society.

\subsection{Summary}

In this chapter, I have discussed the development impacts of irregular economic migration in three aspects: economic gain; human capital gain through education for the next generation; and social change.

The economic impacts of migration are the most direct, visible and widely acknowledged impacts. They affect the migrants and their families directly through the flow of remittances to achieve better living conditions. In an indirect way, I found that the economic outcomes of irregular migration have transformed the infrastructure of the rural community through improvements in housing conditions, as well as boosted the local economy through the increase in flows of goods purchasing.

The second part of the chapter discussed the role of education as a social upward mobility for the younger generation of migrant families. Education in many circumstances is considered a sustainable way towards livelihood betterment and access to higher social status. This discussion follows a previously discussed section about the role of education in the rural area (section 5.3.4).

From the social relations perspective, this chapter has identified the change in agency that the migrant workers achieved through their migration. Across the board, I find that the more assertive and self-motivated one is, the more likely one is to be successful with migration outcomes. The second part of this section discussed the change in gender perspectives towards the role of the male and female stakeholders in the migration process, which includes the female and male migrants as well as their husbands and wives who remained at home. The view towards gender relations in rural society has changed, however this change was found more likely acceptable to the local people because of the space for negotiation that the temporary nature of irregular migration offered to the migrant workers. Additionally, local people's acceptance of these changes was encouraged by the family's economic betterment. From here, the last section of 
the chapter concludes that irregular migration is different to other types of longterm migration in that it allows a space for gender relations to be negotiated. It points out another distinguishing feature of irregular economic migration evident in my case study: families of migrants will arrange for one parent to work overseas and one parent to remain at home tending to existing farm work and caretaking responsibilities. This approach reflects vividly how irregular migration allows families to strategically diversify their sources of income, while at the same time maintaining the family dynamic in the effort of sustaining their livelihood. 
This page is intentionally left blank 


\section{Chapter 7: Irregular migration, migration theory and sustainable rural livelihoods}

\subsection{Revisiting the research questions}

This research has examined the nature of irregular economic migration from the case of four villages in Ha Tinh, a central province in Vietnam. The theoretical framework guiding this research is based on two main approaches, the New Economics of Labour Migration (NELM) theory and the sustainable livelihoods approach (SLA). The linking of these two approaches allows for a comprehensive analysis of the complexities of irregular economic labour migration and its development impacts from the macro level to the micro level of the migration process. I devised three research questions to approach the study subject. In order to assess whether irregular labour migration is a livelihood strategy for local people to diversify and sustain their livelihoods. I explored the process of how irregular migration took place and evolved in the rural community through the perceptions of my research participants, as well as the range of reasons why it has been the strategy adopted by many rural people from the area looking to gain economic betterment through their illegal labour mobility.

It is clear that the process and causes of irregular labour migration are complex and cannot be pinned down to one single reason for how and why people engage with irregular migration. Moving from the process to the end results of migration, my main research question investigated the effects of irregular migration on the migrants, their families and communities at home, linking them to aspects of development in terms of economic and social changes. Chapters Five and Six presented and discussed the detailed findings of the research. They discussed how the process of regulated regular migration may or may not be suitable for many local people, and further, how irregular migration emerged and fitted in the context of Vietnamese labour migration as a more flexible, "quick and easy" strategy for economic gain, especially when regular migration is still expensive 
and rigid in terms of procedures and contracted employment time and, apparently, also brought about negative consequences.

Despite its benefits, irregular labour migration - by its undocumented nature - is risky and creates vulnerabilities. The discussion on the reasons for migration as well as the exploration of the decision-making process highlighted the motives for adopting such a risky approach to economic betterment. At the same time, this analysis shed light on understanding how irregular migration became more possible when the local people found ways to mitigate the risks by adjusting their lives in destination countries to avoid being caught by local authorities.

In sum, irregular labour migration poses challenges, but it also can be an opportunity for sustainable rural livelihoods. The layers of complexity of this migration process cannot be easily generalized given that irregular economic labour migration is contextual, rather new, and there has not been much literature regarding this matter. With this research's findings I hope to offer more insights towards a better understanding of irregular labour migration. In addition, it is hoped that any policy initiatives directed to address the vulnerability and risks of this undocumented movement recognise its many positive impacts in sustaining rural livelihoods, and recognise the needs of irregular migrant workers and the rural poor, rather than simply labelling it in negative terms.

\subsection{Discussion of research findings}

The main conclusion of my research is that even though irregular economic migration from Ha Tinh entails much vulnerability and risk, it has proved to be a choice of livelihood strategy for a portion of local people. Even though the migratory outcomes were found to be diverse among my research participants, it is undeniable that irregular labour migration brings about changes in the rural areas of origin in terms of economic improvement. This case study research refers to irregular migration specifically as "irregular economic labour migration" due to the fact that all participating migrants migrated to earn remittances to serve their households' economic improvement purposes. The migration process can be periodic due to this factor. As migrants worked overseas to earn enough money for their particular purposes, they could return 
home and re-join the family's farm work then migrate again when they were in need of another source of income, in addition to the one they already have at home through farming.

\subsubsection{Irregular migration and the New Economics of Labour Migration theory} In terms of migration impacts, NELM strongly connects households' migration to remittances and households' remittance use (Massey et al., 1993). NELM theorists predicted that the pattern of remitting was for migrants to send their earnings to their households as a "mutually beneficial contractual arrangement" (Stark \& Bloom, 1985, p. 174). The sending of remittances was believed to not only help raise family incomes and provide more insurance against income and production risks, but also to consequently contribute to development through the loosening of production and investment constraints for households in poor developing countries (Taylor, 1999). According to NELM's economic perspective, the remittances are used by households to improve their living standards and consumption, and provide a potential source of investment capital (De Haas, 2007; Taylor, 2004).

The findings in this research support the NELM theory. First of all, my research participants responded to the push and pull of economic development as defined by NELM. Irregular migrant workers studied in this research were found to leave their homeland due to poor economic conditions and low agriculture productivity and economic outcomes. They migrated to earn a better salary for similar types of jobs they could do at home, due to the differences in living conditions and wage rates between destinations. Secondly, the group of interviewees shared that their migratory decisions were shaped by the visible success of other migrants in their community in terms of upgraded housing and new assets. Through wanting similar migratory outcomes as others in their social groups, local people wanted to work overseas to gain better income and improve their living situation. Participants in this study clearly responded to the idea of "relative deprivation" as a motivation for migration that NELM refers to. Thirdly, migration decisions in this case study were found to be made by the households. I found that the families I studied strategically planned for one of their members to work overseas and remit home, while the ones who stayed behind continued 
with their rural farm work. By doing so, families have gained incomes from different streams, and were more secure in case one source of income was at risk. In terms of remittance use, I have found that the remittances were prioritized by my research participants to improve the current living conditions of most households. Only after they had repaid their debts and renovated their houses would families of migrants consider using the remaining remittances as their source of investment capital. Across the research participants, migration outcomes were turned into improved housing conditions for their families. In the rural community, house-building is not only a sign of economic improvement and therefore a way to elevate a family's social status in the community, it is also a meaningful symbol of stability and settlement for a family. Besides housing improvement, there was reportedly family asset accumulation that contributed to the household's better living conditions.

There is less data on the use of remittances as productive investment among my research participants. There was one family who had turned their family member's remittances into an investment by running a local business of a ricehusking workshop, but only after the remittances were first used to improve their housing. Given the nature of irregular, illegal labour migration, as I have discussed in Chapter Five, many irregular migrants stopped migrating once they were content with the remittances they set out to earn. Often this amount was enough for debt repayment and basic living standard improvement, but there was not a significant surplus for a major number of irregular migrants to accumulate for their investments.

There is a distinction in the two purposes of remittance use for improving living conditions and productive investing that NELM envisages. Accordingly, remittances used towards farming and production development are considered "productive investment", while remittances used towards household expenditures are categorized as improving living standards. According to Taylor (2004), various remittance use surveys found that the predominant way remittances were spent was on household expenditures to improve living conditions. Based on these findings, there are critiques that migration and its remittances do not contribute to the local economic development in sending 
areas because remittances only served households' needs. According to this argument, migration is assumed to have a positive effect on economic development if a large amount of the remittances income was reportedly used on "productive investments" directly beneficial to farming production, rather than household consumptions and housing improvement (Taylor, 2004). Housing improvement is not viewed as an investment despite the fact it contributes to the increase of construction work in the community.

In this regard, Taylor argued that many surveys on remittance use do not consider education as an investment because it does not have a direct, immediate employment and income linkage within migration sending economics (ibid, p. 12). I would argue similarly, that education - even though is not an investment in production - can be a type of long-term investment through which the family hope to obtain a better social and economic situation. As discussed in Chapter Six, remittances put towards the education of migrants' children can be considered an investment for future generations to obtain a more sustainable strategy for their livelihoods and support their parents in the longer run. That way, education is the key to social upward mobility for the migrant households. The improvement of human capital, then, would obviously alter the development dynamics of migrants' areas of origin in a more sustainable way.

\subsubsection{Irregular labour migration and sustainable livelihoods}

As much as I found that the type of irregular economic labour migration studied in this research has similar patterns as predicted by NELM theory for regular migration, the irregularity of labour migration makes the study more complex and contextual; therefore the sustainable livelihood approach (SLA) is useful to providing an additional approach to analysing the issue more diversely and indepth.

On a micro level, the SLA approach helps to understand in a specific manner how migratory decisions were made and how the process of migration affects the households in the community. SLA also allows me to explore more social aspects of the migratory impacts on the lives of the migrants, their families and communities that can be limited by the purely economic view of NELM. From a sustainable livelihoods perspective, this research has found that through 
irregular migration, the research participants have mainly gained three types of assets: economic capital (remittances), human capital (education for migrant's children), and social capital (networks and confidence through gaining new knowledge of development and technology through their living experience in foreign countries). These types of asset accumulation indicate how irregular migration has contributed to improving rural living standards, reducing rural poverty through the loosening of financial constraints for migrating households, empowering the local people, and enhancing their capabilities to cope with livelihood shocks. In sum, irregular migration, similar to regular migration, is found to have its contribution as a livelihood strategy for rural people. Additionally, the differences of irregular migration in comparison to regular migration discussed in section 5.4.1, (for example, its lower cost, its flexibility and the possibility it offers to migrant workers to leave and return at any time their families need them), makes irregular migration a far more sustainable contribution to rural livelihoods. Also, although there are not really any organisations involved in the migratory process, networks of acquaintances, friends and community members support the process, making it more secure and also mitigating the vulnerability and risks associated with working illegally. This way of adapting shows how irregular migration fitted in the context of rural Ha Tinh more sustainably for local people.

Drawing from the sustainable livelihood framework, Figure 12 below presents my research findings in a chain diagram to illustrate the key components of the process of how irregular economic labour migration has become a livelihood strategy for local people in Ha Tinh. The diagram shows the causal relationship of the process, starting from the livelihood context that influenced the migratory decisions of local people. In comparison to farming in the context of rural Ha Tinh, irregular migration is viewed as an easier, faster way to earn better income.

As made clear in Chapter Five, the decision-making around irregular labour migration involves comparing the options of staying at home or going overseas. Decision-making was strongly influenced by the poverty push and economic development pull that NELM theory predicts. From the household calculation, irregular migration was made possible through the help of the migrant's social 
networks, introductions to brokers who arranged the trip, and forming groups of acquaintances to migrate with. Specifically, the first irregular migration was found either to be facilitated by a broker whom the migrant worker had paid to be transported to a destination country, or by travelling with a friend or acquaintance who was also an irregular migrant (Field notes, 2016). I found that irregular migration, even though it carries risks and vulnerability since undocumented and illegal, has become even more popular among the rural people of Ha Tinh since the migrants have found their own way to adapt to life in destination countries to avoid trouble with local authorities. In so doing, they have made significant economic gains in supporting their families, not only sustaining but also improving their living conditions. Given that many are opting for irregular migration, this research also highlights that the risks and vulnerability of the matter are being carefully considered.

My research participants were all aware of the risks involved in their illegal migration, however, they seemed to respond more robustly to the economic gains of the migration. They thus adopted this type of migration as a temporary, shortterm strategy to earn another flow of income, while family members at home remained working on the farm. In fact, due to the temporary nature of irregular migration, local people were found to willingly take risks with their illegal working experience, in compensation for the financial gains. The temporary nature of irregular migration is attractive, drawing many local people to this type of migration as a livelihood strategy.

Evidently, the successful migratory outcomes of irregular migrant workers in the villages strongly encouraged others in the local community to do the same. Gradually, the migrant workers were more informed and empowered throughout their migration. As they became more aware of the situation in destination countries, they adjusted to the terms of their migration, maintaining a low profile in the foreign land to ensure, at least from their view, that their migration was successful. Through the sharing of information, and help in facilitating irregular migratory trips, a system has been established in the villages to support those who want to gain economic betterment through irregular migration. It has been found that the positive outcomes of the migration process, in terms of economic, 
social and human capital, have significantly helped local people reduce poverty, enhance their capability and become more resilient in coping with the difficulties of rural livelihoods. Through these positive outcomes, other community members are encouraged to adopt the same approach to sustaining their lives. This factor, relative deprivation, was also envisaged by NELM theory and confirmed by the findings of my research (See Figure 12). 
Figure 12: Mapping irregular migration on to the sustainable livelihood framework
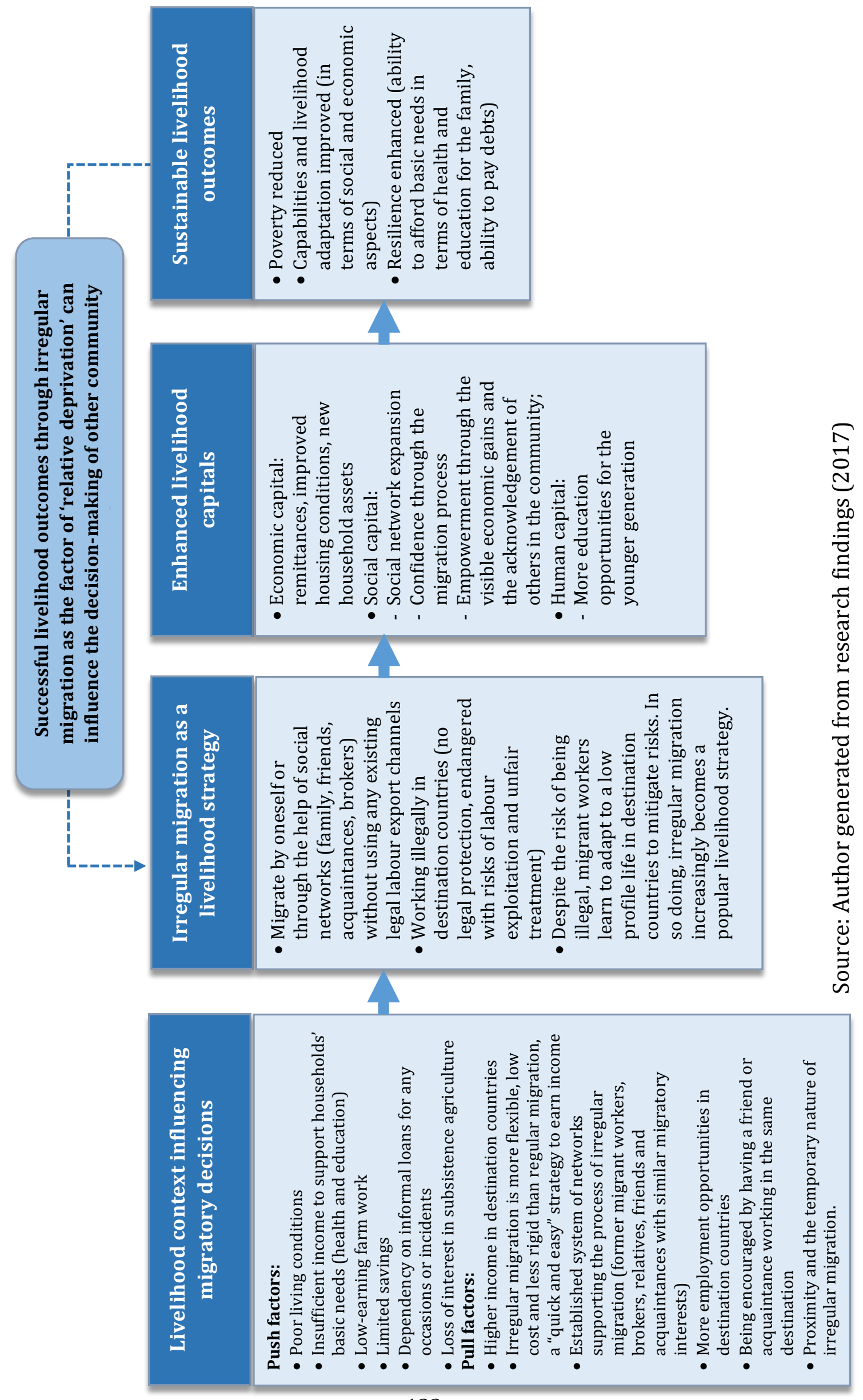
In terms of migrants' agency, this study observes that this may vary in complex ways. Firstly, the research finds that the more self-motivated migrants are, the more successful their migration. The more self-motivated migrants were found to be more positively empowered by gaining and then sharing knowledge with their network. Secondly, the research has identified that irregular migration brings changes in gender dynamics in the home communities of migrants. For example, there were changes in gender roles in the households of migrant workers. Men were found to accept the change in gender roles, and women were found to be more confident and empowered in their roles in the family. Notwithstanding, men remain the head of the household. Throughout the research, female migrant workers were explicitly responsive to the change in gender relations. Even though they risk their lives to gain a better life for their families, these women were also found to feel deeply their sense of gendered responsibility, bringing feelings of guilt if they were unable to fulfil their responsibility. This research acknowledges that such changes in gender relations were compensated by the economic incomes of migration; furthermore, the short period of migration allows these gendered changes to be more easily negotiated.

In terms of social status, even though the outcomes of their migration resulted in better living conditions and higher status in the community, irregular migrant workers, working illegally in low-skilled jobs, remained of low social status in both sending and receiving societies. However, the research finds that those migrant workers were better acknowledged in their home communities, with changes in the way local people viewed them with their economic achievements. In this regard, the confidence the migrants gained through their migration and by achieving migratory outcomes, as well as the acknowledgement of their community, represents a social effect of migration that is gradually changing the social dynamic in the rural community.

\subsection{Research limitations}

This research has several limitations. Firstly, it is worth acknowledging here that the research participants of this study varied across different ages, their period of migration, as well as the time when they migrated. More importantly, no migrant workers had the same starting point prior to their migration due to 
different household situations. Some of the migrant workers who belonged to the oldest group of migrants had stopped working overseas before, while some members of the middle-aged group, as described in the previous chapter, consisted of migrants who were more dynamic and able, and who will continue earning their living through irregular migration in the future. For this reason, there exists a different dynamic among the research participants due to differences in time, economic development, and the employment opportunities they experienced in destination countries through the course of more than a decade of irregular migration. It is, however, the different experience of each migrant worker that paints the picture showing just how diverse and complex irregular migration is. I acknowledge that the research findings can only draw a part of the migrants' experience, and that the findings may also generate discussion and results that fit some migrants' experiences better than others.

Furthermore, here and there in the discussion of this research, I have mentioned the local brokers as the facilitators of irregular migration. I found that these brokers were former migrant workers with extensive experience working overseas and in broad networks. They are no longer irregular workers themselves and in some cases have acquired a legal status in their countries of destination (Field notes, 2016). The research findings do not investigate the role played by these brokers in detail, and instead I have included them as part of the migrants' social networks in the discussion, however their role could have been addressed in more depth.

Thirdly, the research design, as a case study, can make it impossible to generalize the matter on a larger scale. For example, the finding that proximity between $\mathrm{Ha}$ Tinh and some migration destinations offers a reason for the increase of irregular migration from the area is highly contextual due to the strategic location of $\mathrm{Ha}$ Tinh province, close to the borders with Thailand and Laos. The finding therefore does not apply to the small portion of migrants who worked in further destinations. The topic of irregular migration in respect of proximity between home and destination countries needs further investigation should it be considered for other cases. 
Finally, as a Masters student, I am only a novice researcher. I am aware that my ability to conduct the research, to integrate the study methodology and design, as well as my positionality in the field as both an insider and an outsider, can be considered as my limitations. However, I have tried my best to be neutral in my interviews with the research participants, to be flexible with changes during interviews, and have constantly adjusted my research interview guide accordingly. I have attempted to be mindful with my research participants as well as the information I gained through the interviews.

\subsection{Further research recommendations}

More research will be necessary to fully understand how irregular labour migration evolved through time and space in the rural environment of Ha Tinh. This research was conducted in the midst of the booming of Vietnamese irregular labour migration from this area. The dynamics of irregular migration are constantly changing due to changes in migration policy in destination countries as well as the employment opportunities and economic development of labour markets in destination countries. At the time this research was conducted, the findings in remittance use were leaning more towards the spending for household expenditure, however, it is possible that within the coming years this finding will be out of date when more economic gains are realised in local investments. The findings therefore are deemed suitable for the current time. More research conducted later would be able to follow up and provide a more complete picture of remittance use from irregular migration from this province. Moreover, there is room for further research to look at remittance use more specifically. Suggestions for a quantitative study on how and how much the remittances are actually used and what type of businesses benefit from the use of remittances in a detailed manner would be beneficial. Also, as I have acknowledged in the previous section, the role played by local brokers in facilitating and supporting migration workers in the illegal migration process could be made clearer to better benefit the understanding of the complexities of irregular migration.

In terms of education, this study encourages more research to investigate further the role of education as a motivating factor for irregular migration. This research 
has found diverse attitudes and perceptions among local migrant workers towards the future education of their children. Even though all participating migrants with children acknowledged the importance of education for their younger generation, their level of involvement in shaping their children's education varied. On one hand, more research could be useful to study how education plays out as a more sustainable livelihood strategy and in respect of social upward mobility in rural areas. In my view, how education, in the long run, can not only sustain but also transform rural livelihoods should be made robustly clear. Making clearer the linkage between education and rural livelihood betterment has the possibility to become the incentive that encourages more parents to pay proper attention to and investment in their children's education. In other cases, further research can also look at youth employment in the relationship between migration, education and development in the specific case of irregular rural migration.

\subsection{Concluding statement}

It is clear from this research that irregular migration offers a flexible and practical strategy to support the livelihoods of the rural poor in parts of Vietnam. Migration decisions are clearly thought through and are used to earn sufficient income to pay for particular needs, usually in housing and education. This situation is likely to continue unless changes in rural livelihoods offer other economic benefits. While the vulnerabilities of irregular migrants suggest the need for some sort of regulation and protection, this would need to be balanced to ensure the low cost and flexible nature of the labour migration is retained. 
This page is intentionally left blank 


\section{References}

Abreu, A. (2012). The New Economics of Labor Migration: Beware of Neoclassicals Bearing Gifts. Forum for Social Economics, 41(1), 46-67. doi:10.1007/s12143010-9077-2

Adams, R. (2002). Poverty Reduction in Vietnam: 1988 to 1997/98 - A Country Case Study. Retrieved from http://pdf.usaid.gov/pdf docs/Pnacr805.pdf ADB. (2010). Strategy and Action Plan for the Greater Mekong Subregion East-West Economic Corridor. Retrieved from https://www.adb.org/sites/default/files/publication/27496/gms-action-planeast-west.pdf

ADB, \& ILO. (2014). ASEAN Community 2015: Managing integration for better jobs and shared prosperity. Retrieved from https://www.adb.org/sites/default/files/publication/42818/aseancommunity-2015-managing-integration.pdf

Agunias, D., \& Newland, K. (2012). Developing a Road Map for Engaging Diasporas in Development: A Handbook for Policymakers and Practitioners in Home and Host Countries. Geneva: International Organization for Migration.

ASEAN. (2012). ASEAN Agreement on the Movement of Natural Persons. Retrieved from http://www.asean.org/storage/images/2012/Economic/sectoral_aem/service /agreement/ASEAN\%20AGREEMENT\%200N\%20THE\%20MOVEMENT\%200F \%20NATURAL\%20PERSONS.pdf

ASEAN. (n.d.). Building the ASEAN Community: Mutual Recognition Arrangements in Services - ASEAN Professional on the Move. Retrieved from http://www.asean.org/storage/images/2015/October/outreachdocument/Edited\%20MRA\%20Services-2.pdf

Baldwin-Edwards, M. (2008). Towards a Theory of Illegal Migration: historical and structural components. Third World Quarterly, 29(7), 1449-1459. doi:10.1080/01436590802386690

Barry, K. (2006). Home and away: the construction of citizenship in an emigration context. New York University Law Review, 81, 11-2192.

Barslund, M., \& Tarp, F. (2008). Formal and Informal Rural Credit in Four Provinces of Vietnam. The Journal of Development Studies, 44(4), 485-503. doi:10.1080/00220380801980798

Beazley, H., \& Desai, V. (2014). Gender and globalisation. In V. Desai \& R. Potter (Eds.), The Companion to Development Studies (3 ed.). London \& New York: Routledge. 
Bélanger, D., Ueno, K., Hong, K. T., \& Ochiai, E. (2011). From Foreign Trainees to Unauthorized Workers: Vietnamese Migrant Workers in Japan. Asian and Pacific Migration Journal, 20(1), 31-53. doi:10.1177/011719681102000102

Berlinger, J. (2017, January 25). TPP unravels: Where the 11 other countries go from here? CNN. Retrieved from http://edition.cnn.com/2017/01/24/asia/tppother-11-countries-what-next/

Binns, T. (2013). Dualistic and unilinear concepts of development. In Vandana Desai \& R. Potter (Eds.), The companion to development studies: Routledge.

Booth, A., \& Le, H. (2010). Inequality in Vietnamese Urban-Rural Living Standards, 19932006 (Discussion Paper No. 4987). Retrieved from Bonn, Germany: http://repec.iza.org/dp4987.pdf

Boyle, P., Halfacree, K., \& Robinson, V. (1998). Exploring contemporary migration. London: Longman

Caouette, T., Sciortino, R., Guest, P., \& Feinstein, A. (2006). Labour migration in the Greater Mekong Sub-region. Retrieved from Bangkok, Thailand: http://apmrn.anu.edu.au/regional members/LaborMigration\%20in\%20GMS.p $\underline{\mathrm{df}}$

Castles, S. (2009). Development and Migration or Migration and Development: What Comes First? Asian and Pacific Migration Journal, 18(4), 441-471. doi:10.1177/011719680901800401

Castles, S., Cubas, M. A., Kim, C., \& Ozkul, D. (2012). Irregular Migration: Causes, Patterns, and Strategies. In I. Omelaniuk (Ed.), Global Perspectives on Migration and Development: GFMD Puerto Vallarta and Beyond (pp. 117-151). Dordrecht: Springer Netherlands.

Castles, S., \& Miller, M. J. (2009). The age of migration : international population movements in the modern world (4th ed.). Basingstoke, England: Palgrave Macmillan.

Chacko, E. (2004). Positionality and Praxis: Fieldwork Experiences in Rural India. Singapore Journal of Tropical Geography, 25(1), 51-63. doi:10.1111/j.01297619.2004.00172.x

Chiswick, B. (2008). Are immigrants favorably self-selected? An economic analysis. In C. Brettell \& J. Hollified (Eds.), Migration theories: talking across disciplines (2 ed.). New York: Routledge.

CIA. (2015). Vietnam Country Information. Retrieved October 20, from Central Intelligence Agency (CIA) https://www.cia.gov/library/publications/theworld-factbook/geos/vm.html 
Creswell, J. W. (2003). Research design : qualitative, quantitative, and mixed methods approaches (2nd ed.). Thousand Oaks, California: SAGE Publications.

Creswell, J. W. (2009). Research design : qualitative, quantitative, and mixed methods approaches (3rd ed.). Thousand Oaks, California: SAGE Publications.

Creswell, J. W. (2014). Research design : qualitative, quantitative, and mixed methods approaches (4th ed.). Thousand Oaks: SAGE Publications.

Crotty, M. (1998). The foundations of social research : meaning and perspective in the research process. St Leonards, NSW: Allen \& Unwin.

Dang, N. A. (2008). Labor Migration from Vietnam: Issues of policy and practice.

Retrieved from Bangkok, Thailand:

http://www.ilo.org/wcmsp5/groups/public/---asia/---robangkok/documents/publication/wcms_099172.pdf

Dang, N. A., Tacoli, C., \& Hoang, X. T. (2003). Migration in Vietnam: A review of information on current trends and patterns, and their policy implications. Retrieved from http://pubs.iied.org/pdfs/G00479.pdf

De Haas, H. (2007). Remittances, migration and social development: a conceptual review of the literature (34). Retrieved from http://citeseerx.ist.psu.edu/viewdoc/download?doi=10.1.1.515.9483\&rep=rep 1 \&type $=\mathrm{pdf}$

De Haas, H. (2008). Migration and development: a theoretical perspective. International Migration Institute, Working Paper 9

De Haas, H. (2010). Migration and development: a theoretical perspective. International migration review, 44(1), 227-264.

Délano, A., \& Gamlen, A. (2014). Comparing and theorizing state-diaspora relations. Political Geography, 41, 43-53.

Denscombe, M. (2014). The good research guide: for small-scale research projects (5 ed.). Maidenhead, Berkshire: Open University Press.

Desai, V., \& Potter, R. B. (Eds.). (2013). The companion to development studies (Third ed.): Routledge.

DeWind, J., \& Ergun, D. (2013). Development and Migration: Historical trends and future research. In J. Cortina \& E. Ochoa-Reza (Eds.), New Perspective on International Migration and Development. New York: Columbia University Press.

DFID. (1999). Sustainable livelihood guidance sheets. Retrieved from Department for International Development (DFID):

http://www.eldis.org/vfile/upload/1/document/0901/section2.pdf 
Dollar, D., \& Litvack, J. (1998). Macroeconomic Reform and Poverty Reduction in Vietnam. In D. Dollar, P. Glewwe, \& J. Litvack (Eds.), Household Welfare and Vietnam's Transition. Washington D.C.: World Bank.

Drummond, L., \& Rydstrøm, H. (Eds.). (2004). Gender practices in contemporary Vietnam. Copenhagen: NIAS Press.

Elliott, J. A. (2013). An introduction to sustainable development (4th ed.). Abingdon, Oxon: Routledge.

Fukunaga, Y. (2015). Assessing the progress of ASEAN MRAs on professional services. Retrieved from http://www.eria.org/ERIA-DP-2015-21.pdf

Fukunaga, Y., \& Ishido, H. (2015). Values and limitations of the ASEAN Agreement on the Movement of Natural Persons. Retrieved from http://www.eria.org/ERIA-DP2015-20.pdf

Gamlen, A., Murray, W. E., \& Overton, J. (2016). Investigating education, migration and development-Moving triangles in the Pacific. New Zealand Geographer, 1-12. doi:10.1111/nzg.12146

Gilbert, M. R. (1994). The Politics of Location: Doing Feminist Research at "Home". The Professional Geographer, 46(1), 90-96. doi:10.1111/j.0033-0124.1994.00090.x

Gray, D. E. (2004). Doing research in the real world. Thousand Oaks, California: SAGE Publications.

GSO. (2015). General Statistics Office of Vietnam. Retrieved from http://www.gso.gov.vn/

Ha Tinh DOLISA. (2016a). Discussion on Ha Tinh's internal and external labour migration in the period of 2005 - 2016. Department of Labour, Invalids and Social Affairs, Ha Tinh Province. Unpublished.

Ha Tinh DOLISA. (2016b). Regulation on the function, task, power and organization of DOLISA. Retrieved 19 December from Department of Labour, Invalids and Social Affairs, Ha Tinh Province http://ldtbxhhatinh.gov.vn/index.php?nv=about\&op=Chuc-nang-nhiem-vu

Ha Tinh E-Portal. (2016). Overview of Ha Tinh Province. Retrieved October 20, from Ha Tinh E-Portal http://hatinh.gov.vn/Pages/Gi\%E1\%BB\%9Bithi\%E1\%BB\%87u.aspx

Ha Tinh Economic Zone Authority. (2017). Introduction of Ha Tinh Economic Zone. Retrieved from http://kkthatinh.gov.vn/?s=41/introduction/about-heza

Harvie, C., \& Tran, V. H. (1997). Vietnam's reforms and economic growth. Basingstoke, Hampshire: MacMillan Press. 
Hay, I. (2010). Qualitative research methods in human geography (3rd ed.). Oxford, New York: Oxford University Press.

Hoang, L. (2011). Gender Identity and Agency in Migration Decision-Making: Evidence from Vietnam. Journal of Ethnic and Migration Studies, 37(9), 1441. doi:10.1080/1369183X.2011.623618

Hofmann, E. T., \& Buckley, C. J. (2013). Global changes and gendered responses: the feminization of migration from Georgia. International Migration Review, 47(3), 508-538.

Huelser, S., \& Heal, A. (2014). Moving freely? Labour mobility in ASEAN. Asia-Pacific Research and Training Network on Trade Policy Brief, 40.

ILO Vietnam. (2015). Regular and irregular migrant workers in North Central Viet Nam: Findings from household surveys. Retrieved from http://www.ilo.org/wcmsp5/groups/public/---asia/---ro-bangkok/---ilohanoi/documents/publication/wcms_379368.pdf

IOM. (2015). International Organization for Migration. Retrieved from https://www.iom.int/key-migration-terms

Koser, K. (2009). Dimensions and dynamics of irregular migration. Population, Space and Place, 16, 181-193. doi:10.1002/psp.587

Kumar, R. (2014). Research methodology: A step-by-step guide for beginners (4th ed.). Los Angeles: SAGE Publications.

Le, H., Duong, T., Simelton, E., Ferrer, A., Bui, Y., \& Leocadio, S. (2015). Situation Analysis and Needs Assessment Report for My Loi village and Ha Tinh province, Viet Nam. Retrieved from Copenhagen, Denmark: www.ccafs.cgiar.org

Litvack, J., \& Rondinelli, D. (Eds.). (1999). Market reform in Vietnam : building institutions for development. Westport, Connecticut: Quorum Books.

Massey, D., Arango, J., Hugo, G., \& Taylor, J. (1993). Theories of international migration: A review and appraisal. Population and Development Review, 19(3), 431.

McDowell, C., \& De Haan, A. (1997). Migration and Sustainable Livelihoods: A Critical Review of the Literature. Retrieved from http://www.ids.ac.uk/publication/migration-and-sustainable-livelihoods-acritical-review-of-the-literature

Merriam, S. B. (2009). Qualitative research: a guide to design and implementation. In S. B. Merriam \& C. Ebooks (Eds.). San Francisco: Jossey-Bass.

Ministry of Agriculture and Rural Development (MARD). (2015). Implementation report for agriculture sector for the first 9 months of 2015. Retrieved from 
http://www.mard.gov.vn/Lists/appsp01_statistic/Attachments/96/Baocao_T9

\section{5.pdf}

Morse, S., \& McNamara, N. (2013). Sustainable Livelihood Approach: A Critique of Theory and Practice. Dordrecht: Springer.

Munck, R. (2008). Globalisation, Governance and Migration: an introduction. Third World Quarterly, 29(7), 1227-1246. doi:10.1080/01436590802386252

Nguyen, B. G. (2012). Potential Economic Corridors between Vietnam and Lao PDR: Roles Played by Vietnam. In M. Ishida (Ed.), Emerging Economic Corridors in the Mekong Region (Vol. BRC Research Report No. 8). Bangkok, Thailand: Bangkok Research Center, IDE-JETRO.

OECD. (2015). Agricultural policies in Vietnam 2015. Retrieved from OECD Publisher, Paris: http://dx.doi.org/10.1787/9789264235151-en

Østergaard-Nielsen, E. D. (2003). International Migration and Sending Countries : Perceptions, Policies and Transnational Relations. Basingstoke, UK: Palgrave Macmillan.

Pedraza, S. (1991). Women and Migration: The Social Consequences of Gender. Annual Review of Sociology, 17(1), 303-325. doi:10.1146/annurev.so.17.080191.001511

Pham, B. N., \& Hill, P. (2008). The role of temporary migration in rural household economic strategy in a transitional period for the economy of Vietnam. Asian Population Studies, 4(1), 57-75. doi:10.1080/17441730801966683

Pillow, W. (2003). Confession, catharsis, or cure? Rethinking the uses of reflexivity as methodological power in qualitative research. International Journal of Qualitative Studies in Education, 16(2), 175-196.

doi:10.1080/0951839032000060635

Piper, N. (2008). Feminisation of Migration and the Social Dimensions of Development: the Asian case. Third World Quarterly [H.W.Wilson - SSA], 29(7), 1287.

RFA. (2016). Formosa Steel Owns Up to Toxic Spill, Agrees to Pay Vietnam $\$ 500$ Million. Radio Free Asia.

Richards, L. (2005). Handling qualitative data: a practical guide. London: SAGE Publications.

Rigg, J. (2006). Land, farming, livelihoods, and poverty: Rethinking the links in the Rural South. World Development, 34(1), 180-202. doi:10.1016/j.worlddev.2005.07.015

Rose, G. (1997). Situating knowledges: positionality, reflexivities and other tactics. Progress in human geography, 21(3), 305-320. 
Rowley, C., \& Truong, Q. (2009). Setting the scene for the changing face of management in Vietnam. In C. Rowley \& Q. Truong (Eds.), The changing face of Vietnamese management. New York: Routledge.

Scheyvens, R., \& Storey, D. (Eds.). (2003). Development fieldwork: a practical guide. London, UK: SAGE Publications.

Scoones, I. (1998). Sustainable rural livelihoods: a framework for analysis. IDS Working Paper, 72.

Scoones, I. (2009). Livelihoods perspectives and rural development. The Journal of Peasant Studies, 36(1), 171-196. doi:10.1080/03066150902820503

Set Aung, W. (2009). Illegal Heroes and Victimless Crimes: Informal Cross-border Migration from Myanmar: a Comparative View. Stockholm: Institute for Security and Development Policy.

Sinatti, G., \& Horst, C. (2015). Migrants as agents of development: Diaspora engagement discourse and practice in Europe. Ethnicities, 15(1), 134-152. doi:10.1177/1468796814530120

Stark, O., \& Bloom, D. (1985). The New Economics of Labor Migration. The American Economic Review, 75(2), 173.

Sultana, F. (2007). Reflexivity, Positionality and Participatory Ethics: Negotiating Fieldwork Dilemmas in International Research. ACME: An International EJournal for Critical Geographies, 6(3), 374-385.

Taylor, J. E. (1999). The New Economics of Labour Migration and the Role of Remittances in the Migration Process. International Migration, 37(1), 63-88. doi:10.1111/1468-2435.00066

Taylor, J. E. (2004). Remittances, Savings, and Development in Migrant-Sending Areas: Oxford University Press.

The University of Texas Library. (n.d.). Map collection. Retrieved November 2, from The University of Texas Library http://www.lib.utexas.edu/maps/middle_east_and_asia/vietnam_admin_2001. pdf

Tran, T. (2016). Ha Tinh boosting industrial development creating a breakthrough in socio-economic development. Retrieved from https://www.gso.gov.vn/default en.aspx?tabid=467\&idmid=3\&ItemID=15751

UNDP. (2014). UN Human Development Index. Retrieved from http://hdr.undp.org/sites/all/themes/hdr_theme/country-notes/VNM.pdf

Van Arkadie, B., \& Mallon, R. (2004). Viet Nam - a transition tiger? Canberra: ANU E Press \& Asia Pacific Press. 
Vietnam Consular Department. (2011). Vietnam Emigration Report. Ministry of Foreign Affairs. Unpublished.

Vietnam Government E-portal. (2016). Vietnam Geography. Retrieved from http://www.chinhphu.vn/portal/page/portal/chinhphu/NuocCHXHCNVietNa $\underline{m}$ /ThongTinTongHop/dialy

Vietnam Invest Network Corporation. (n.d.). Map of Ha Tinh. Retrieved from http://investinvietnam.vn/data/image/Ha\%20Tinh(2).jpg

Weinar, A. (2010). Instrumentalising diasporas for development: International and European policy discourses. In R. Bauböck \& T. Faist (Eds.), Diaspora and Transnationalism: Concepts, Theories and Methods (pp. 73). Amsterdam: Amsterdam University Press.

Werner, J., Belanger, D. (2002). Gender, Household, State: Doi Moi in Vietnam. U.S.S: Cornell Southeast Asia Program Publications.

Winkels, A., \& Adger, W. N. (2002). Sustainable livelihoods and migration in Vietnam: the importance of social capital as access to resources. Paper presented at the International Symposium on Sustaining Food Security and Managing Natural Resources in Southeast Asia-Challenges for the 21st Century.

World Bank. (2004). Environmental Assessment for Rural Energy II Project in Ha Tinh. Retrieved from Vietnam: http://documents.worldbank.org/curated/en/247411468308962601/pdf/E9 590vol050paper.pdf

World Bank. (2013). World Bank Supports Livelihoods Improvement for Poorest Areas of Vietnam's Central Highlands. Retrieved from http://www.worldbank.org/en/news/press-release/2013/12/27/world-banksupports-livelihoods-improvement-for-poorest-areas-vietnams-centralhighlands

World Bank. (2015). Data. Retrieved from http://data.worldbank.org/indicator/NY.GNP.PCAP.CD

World Bank. (2016). Vietnam Overview. Retrieved from http://www.worldbank.org/en/country/vietnam/overview

Yamanaka, K., \& Piper, P. (2005). Feminized Migration in East and Southeast Asia: Policies, Actions and Empowerment. Retrieved from Switzerland: http://www.unrisd.org/80256B3C005BCCF9/(httpPublications)/06C975DEC6 217D4EC12571390029829A?OpenDocument

Yin, R. K. (2009). Case study research: design and methods (4th ed.). Los Angeles, California: SAGE Publications. 


\title{
Appendices \\ Appendix 1: Participant information sheet (in English)
}

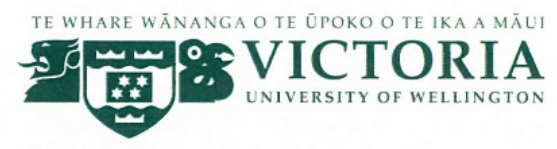

\author{
Vietnamese Irregular Migration: \\ A study on the development impacts of irregular economic migration \\ INFORMATION SHEET FOR PARTICIPANTS
}

\author{
Researcher: Hang Thi Trinh
}

Supervisor: Dr. Polly Stupples

\begin{abstract}
Thank you for your kind interest in this project. Please read the information provided below to gain a better understanding of the research project before deciding whether or not to take part. If you decide to participate, thank you. However, if you do not wish to be a participant, I thank you for considering my request and wish you all the best. Please be noted that should you wish to withdraw from this project, you can do so within 04 weeks after the interview date by contacting myself or my supervisor. We ensure there will be no harm or disadvantage to you in the case of your withdrawal from the project.
\end{abstract}

Who am I?

My name is Hang Thi Trinh and I am a Master student in Development Studies at Victoria University of Wellington, New Zealand. My research will explore the social and economic impacts of the irregular migration process on migrant workers, their families and community in Vietnam. This research project is work towards my thesis as a requirement of graduation.

What is the aim of the project?

The main objective of my research is to study the experience of returned irregular migrant workers from two provinces of Vietnam, who decided to go abroad to work without using the services of any legalised state-owned or private labour recruitment agencies. In doing so, I want to understand, from the migrants' perspective, the effects of the irregular migration process on migrant workers, their families and communities in terms of social status, opportunity and economic betterment. The proposal of this research project has been reviewed and approved by Victoria University of Wellington.

How can you help?

If you have gone abroad from Vietnam without the arrangement or services of any legalised stateowned or private labour recruitment agencies to work; or if you have family member(s) who have gone abroad without using the services of any labour recruitment agency; or if your community has people who have gone abroad without using any services of a labour recruitment agency, I would appreciate your consideration taking part in this study. If you agree to take part, I would like to interview you at a time and place that is most suitable for you. The interview will take place for one 
(01) hour with casual conversation about Vietnamese irregular economic migration and your experience and understanding regarding the matter. I would like to record the interview using an MP3 recorder and write it up later in order to maintain the flow of our conversation. You can stop the interview, refuse to answer any question or decide to go off record at any time, without giving a reason. You can withdraw from the study up to four weeks after the interview date. If you withdraw, the information you provided will be destroyed or returned to you.

\section{What will happen to the information you give?}

Your sharing is valuable information that contributes to the completion of my Master Thesis. This research is confidential thus the information you provided will be treated with respect and confidentiality. I will not name you in any reports, and I will not include any information that would identify you. Only my supervisors and I will read the notes or transcripts of the interview. I may quote your words for cases of illustration in the research; however, all pseudonyms will be used to protect your identity. The interview transcripts, summaries and any recordings will be kept securely and destroyed 02 years after the research ends. You will have time to ask any questions you may have during our conversations, and at the end of the interview if you wish to have any clarification or a summary of our discussion, you can request for a transcript of the interview to be sent to you and make any revision as you see fit.

\section{What will the project produce?}

This research has been approved by Victoria University of Wellington Human Ethics Committee. The information from this research will be used in my Master thesis to submit to Victoria University of Wellington as a requirement for completion of my Master degree. I may also use the results of my research to present at conferences, produce news report or journal articles and academic reports. I wish to provide the findings to relevant community members to offer a better understanding of the situation of irregular migration in Vietnam. If you wish to receive a summary of the findings, please kindly let me know during the interview. I will take care not to identify you or any of the participants in any presentation or report. 
If you have any questions or problems, who can you contact?

If you have any questions, either now or in the future, please feel free to contact either:

Student:

Name: Hang Thi Trinh

Email: HangThi.Trinh@vuw.ac.nz

Phone: +64 221568007 (NZ)

+84988189142(VN)

\section{Supervisor:}

Name: Dr. Polly Stupples

School of Geography, Environment and

Earth Science

Email: polly.stupples@vuw.ac.nz

Phone: +64 44636793

\section{Human Ethics Committee information}

If you have any concerns about the ethical conduct of the research you may contact the Victoria University HEC Convener: Associate Professor Susan Corbett. Email susan.corbett@vuw.ac.nz or telephone +64-4-4635480. 


\title{
Appendix 2: Participant information sheet (in Vietnamese)
}

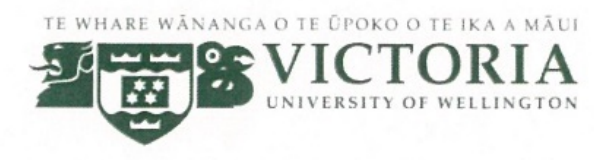

\section{Trường Đai hoc Victoria tai Wellington, Niu Di Lân}

Đề tài: Tác động kinh tế và xã hội của quá trình di cư lao động qua các kênh không chính thức tại Việt Nam

\section{THÔNG TIN DÀNH CHO NGƯỜI THAM GIA}

\author{
Nghiên cứu sinh: Trịnh Thị Hằng Giáo viên hướng dẫn: TS. Polly Stupples
}

Xin chào Quý Anh/ Chị!

Xin cám ơn Anh/ Chị đã dành thời gian quý báu xem xét phiếu thông tin này trước khi quyết định tham gia đề tài nghiên cứu. Tôi tên là Trịnh Thị Hằng, hiện đang là sinh viên cao học ngành Nghiên cứu Phát triển tại Đại học Victoria tại Wellington, Niu Di Lân. Hiện tôi đang thực hiện đề tài nghiên cứu về các tác động phát triển về kinh tế và xã hội của quá trình di cư lao động qua các kênh không chính thức tại Việt Nam. Dự án nghiên cứu được xây dựng với mong muốn tìm hiểu các tác động của quá trình di cư lao động qua các kênh không chính thức đối với người lao động di cư, gia đình và cộng đồng xã hội thông qua chia sẻ từ phía những người trong cuộc; từ đó đánh giá các thay đổi về cơ hội phát triển kinh tế và vị thế xã hội do quá trình di cư qua các kênh không chính thức đưa lại cho các bên liên quan trong bối cảnh phát triển của Việt Nam. Dựa trên kết quả nghiên cứu, đề tài mong muốn đưa ra được một số giải pháp cũng như gợi ý xây dựng chính sách phù hợp với thực trạng di cư lao động không chính thức ở Việt Nam trong những năm gần đây.

Các thông tin do Anh/ Chị cung cấp sẽ được bảo mật, danh xưng và thông tin cá nhân sẽ được thay đổi nhằm mục đích bảo vệ danh tính người tham dự. Trong vòng 4 tuần kể từ ngày tham gia phỏng vấn, Anh/ Chị có quyền rút lui khỏi nghiên cứu bằng cách liên hệ với nghiên cứu sinh hoặc giáo viên hướng dẫn. Chúng tôi xin đảm bảo tôn trọng quyết định của Anh/ Chị và các thông tin do Anh/ Chị cung cấp sẽ được rút khỏi dữ liệu của dự án.

\section{Mục đích nghiên cứu}

Mục đích chính của nghiên cứu là tìm hiểu các trải nghiệm của lao động di cư theo các kênh không chính thức từ hai tỉnh, thành phố tại Việt Nam. Di cư theo các kênh không chính thức trong khuôn khổ đề tài nghiên cứu này được hiểu là các lao động di cư đi làm việc ở nước ngoài không thông qua các trung tâm môi giới và tuyển dụng lao động chính thức của nhà nước hay tư nhân tại Việt Nam. Từ việc tìm hiểu và phỏng vấn sâu cùng các lao động di cư 
không chính thức đã trở về, gia đình và lãnh đạo làng/ xã tại địa phương, dự án mong muốn đưa ra đánh giá chân thực từ phía người lao động và gia đình, cộng đồng về các tác động, thay đổi về phát triển kinh tế và xã hội của quá trình di cư không chính thức. Bản đề xuất dự án này đã được phê duyệt bởi Hội đồng Nghiên cứu trường đại học Victoria tại Wellington, Niu Di Lân.

\section{Đối tượng phỏng vấn và bảo mật thông tin}

Nếu Anh/ Chị đã từng đi nước ngoài làm việc không thông qua dịch vụ của các trung tâm tuyển dụng xuất khẩu lao động trong nước, hoặc nếu Anh/ Chị có người thân trong gia đình đã từng hoặc đang đi làm việc tại nước ngoài theo hướng tự đi, không qua trung tâm tuyển dụng lao động; hoặc nếu trong làng/ xã của Anh/ Chị có người lao động di cư theo hình thức tự đi, không thông qua trung tâm tuyển dụng xuất khẩu lao động, rất mong được $\mathrm{Anh} / \mathrm{Chị}$ dành chút thời gian trao đổi với nghiên cứu sinh. Dự án xin phép được trao đổi với $\mathrm{Anh} / \mathrm{Chị}$ trong khoảng 60 phút về các thông tin Anh/ Chị có được về vấn đề di cư lao động thông qua các kênh không chính thức tại Việt $\mathrm{Nam}$. Anh/ Chị có thể lựa chọn địa điểm và thời gian tham gia trả lời phỏng vấn, dự án xin được $\mathrm{Anh} / \mathrm{Chị} \mathrm{cho} \mathrm{phép} \mathrm{ghi} \mathrm{âm} \mathrm{quá} \mathrm{trình} \mathrm{trao} \mathrm{đổi} \mathrm{bằng}$ máy ghi âm để tránh việc ghi chép có thể làm gián đoạn cuộc nói chuyện với Anh/ Chị. Anh/ Chị có quyền tạm dừng cuộc trao đổi, từ chối trả lời cũng như trả lời không chính thức, không ghi âm đối với bất cứ phần trao đổi nào và không cần đưa ra lí do. Như đã đề cập ở trên, Anh/ Chị có quyền từ chối hoặc rút lui khỏi dự án trong vòng 4 tuần kể từ ngày tham gia phỏng vấn, trong trường hợp đó, các thông tin do Anh/ Chị cung cấp sẽ được rút khỏi dữ liệu dự án và chúng tôi xin đảm bảo tôn trọng tính bảo mật cũng như danh tính của Anh/ Chị.

Những thông tin do Anh/ Chị cung cấp đóng vai trò vô cùng quan trọng cho việc hoàn thành dự án này. Dự án này là nghiên cứu độc lập và tuân thủ nguyên tắc bảo mật cũng như quy định về đạo đức nghiên cứu của các nghiên cứu khoa học, do đó các thông tin thu được qua quá trình trao đổi với Anh/ Chị sẽ được bảo mật và tôn trọng nghiêm ngặt. Chúng tôi sẽ không nêu tên hay địa danh nơi $\mathrm{Anh} / \mathrm{Chị} \mathrm{sinh} \mathrm{sống} \mathrm{hay} \mathrm{tiết} \mathrm{lộ} \mathrm{bất} \mathrm{cứ} \mathrm{thông} \mathrm{tin} \mathrm{nào} \mathrm{có} \mathrm{thể} \mathrm{tiết}$ lộ danh tính của người tham dự. Thông tin dự án sẽ được xử lý nghiêm túc và tuân thủ tính riêng tư và bảo mật, chỉ nghiên cứu sinh và giáo viên hướng dẫn được phép đọc các ghi chép và biên bản phỏng vấn sau khi đã được đánh máy từ cuộc hội thoại được ghi âm. Dự án có thể sẽ sử dụng một số thông tin Anh/ Chị chia sẻ để làm tài liệu diễn giải, tuy nhiên vấn đề bảo mật sẽ được đặt lên hàng đầu, danh xưng, địa danh, thông tin cá nhân hay bất cứ thông tin nào có thể làm lộ danh tính của $\mathrm{Anh} / \mathrm{Chị} \mathrm{sẽ} \mathrm{được} \mathrm{thay} \mathrm{đổi} \mathrm{vì} \mathrm{lí} \mathrm{do} \mathrm{này.} \mathrm{Các} \mathrm{thông} \mathrm{tin} \mathrm{thu}$ được trong quá trình phỏng vấn sẽ được lưu trong vòng 2 năm sau khi dự án kết thúc vào 
tháng 3 năm 2017. Anh/ Chị có thể đưa ra bất kì câu hỏi hay yêu cầu nào đối với thông tin Anh/ Chị cung cấp cũng như về mục đích của dự án, dựa theo yêu cầu của Anh/ Chị, chúng tôi có thể gửi Anh/ Chị biên bản đánh máy của cuộc phỏng vấn để Anh/ Chị xem lại cũng như có những điều chỉnh phù hợp nếu cần thiết.

Dự án này đã được Uỷ ban Đạo đức nghiên cứu Trường đại học Victoria tại Wellington, Niu Di Lân phê duyệt. Thông tin dự án thu được sẽ được sử dụng làm báo cáo tốt nghiệp Thạc sĩ của nghiên cứu sinh. Kết quả của nghiên cứu có thể được sử dụng làm tài liệu trình bày hội thảo hoặc viết báo nếu có cơ hội. Kết quả dự án cũng sẽ được chia sẻ tới các địa phương để cung cấp thêm thông tin về tình hình cũng như các tác động kinh tế, xã hội của quá trình di cư thông qua các kênh không chính thức đối với người lao động, gia đình và xã hội. Xin Anh/ Chị cho dự án biết nếu Anh/ Chị muốn nhận bảng tóm tắt kết quả dự án sau khi đã hoàn thành. Dự án xin đảm bảo không để lộ danh tính của Anh/ Chị trong bất cứ tài liệu trình bày nào sau khi hoàn tất.

Rất mong nhận được sự tham gia của Anh/Chị!

Trong trường hợp Anh/Chị có thắc mắc cũng như cần liên hệ với chúng tôi:

\section{Nghiên cứu sinh}

Trịnh Thị Hằng

Địa chỉ email $\underline{\text { HangThi.Trinh@vuw.ac.nz }}$

ĐT : +64 221568007 (tại Niu Di Lân)

+84988189142 (tại Việt Nam )

\section{Giáo viên hướng dẫn}

Tiến sĩ Polly Stupples

Khoa Địa lý nhân văn, Địa chất và Khoa học Môi trường, trường Đại học Victoria tại TP. Wellington, Niu Di Lân

Email: polly.stupples@vuw.ac.nz

ĐT: +64 44636793 (tại Niu Di Lân)

Uỷ ban Đạo đức Nghiên cứu (HEC), trường Đại học Victoria tại Wellington.

Nếu Anh/ Chị có bất cứ thắc mắc nào về quá trình tuân thủ đạo đức của dự án nghiên cứu này, xin mời liên hệ Uỷ ban Đạo đức con người, trường Đại học Victoria tại Thành phố Wellington, Niu Di Lân theo thông tin sau: Giáo sư Susan Corbett. Email: susan.corbett@vuw.ac.nz; ĐT: +64-4-463 5480. 


\section{Appendix 3: Interview consent form (in English)}

TE WHARE WĀNANGA O TE ŨPOKO O TE IKA A MÃU

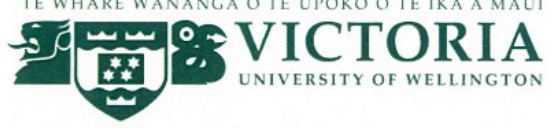

Vietnamese Irregular Migration: A study on the development impacts of irregular economic migration

\section{CONSENT TO INTERVIEW}

This consent form will be held for [5] years.

Researcher: Hang Thi Trinh,

School of Geography, Environment and Earth Sciences, Victoria University of Wellington.

- I have read the Information sheet and the project has been explained to me. My questions have been answered to my satisfaction. I understand that I can ask further questions at any time.

- I agree to take part in an audio recorded interview.

I understand that:

- I may withdraw from this study up to fout (04) weeks after the interview, and any information that I have provided will be returned to me or destroyed.

- The information I have provided will be destroyed 2 years after the research is finished.

- Any information I provide will be kept confidential to the researcher and the supervisor. I understand that the results will be used for a Master thesis and a summary of the results may be used in academic reports and/or presented at conferences.

- My name will not be used in reports, nor will any information that would identify me.

- I would like a copy of the transcript of my interview: Yes No

- I would like a summary of my interview: $\quad$ Yes No

- I would like to receive a copy of the final report and have added my email Yes No address below.

Signature of participant:

Name of participant:

Date:

Contact details: 


\section{Appendix 4: Interview consent form (in Vietnamese)}

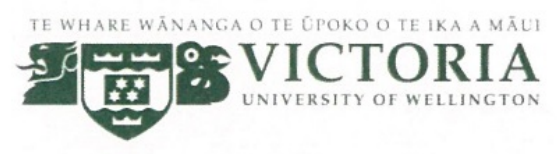

Trường Đai hoc Victoria tai Wellington, Niu Di Lân

Đề tài: Tác động kinh tế và xã hội của quá trình di cư lao động qua các kênh không chính thức tại Việt Nam

Phiếu đồng ý tham gia phỏng vấn

Phiếu thông tin này sẽ được lưu trong vòng 5 năm

Nghiên cứu sinh: Trịnh Thị Hằng, Khoa Địa lý nhân văn, Địa chất và Khoa học Môi trường, trường Đại học Victoria tại TP. Wellington, Niu Di Lân

- Tôi xác nhận đã đọc kĩ phiếu thông tin dành cho người tham gia và được giải thích về mục đích của dự án nghiên cứu cũng như các quyền của người tham gia dự án. Các thắc mắc của tôi đã được giải đáp và tôi có thể có bất cứ câu hỏi thêm nào trong thời gian phỏng vấn.

- Tôi đồng ý cho dự án ghi âm cuộc phỏng vấn

Tôi hiểu rằng:

- Tôi có quyền rút lui khỏi dự án nghiên cứu trong vòng 4 tuần kể từ ngày tham gia phỏng vấn, các thông tin do tôi cung cấp trong trường hợp đó, sẽ được gửi trả lại cho tôi hoặc bị tiêu huỷ.

- Các thông tin do tôi cung cấp sẽ bị tiêu huỷ sau 2 năm khi dự án kết thúc.

- Các thông tin do tôi cung cấp sẽ được bảo mật và chỉ nghiên cứu sinh và giáo viên hướng dẫn có quyền tiếp cận các thông tin này. Kết quả dự án được sử dụng để hoàn thành báo cáo tốt nghiệp Thạc sĩ của nghiên cứu sinh. Các kết quả dự án có thể được sử dụng trong một số bài trình bày và báo cáo khoa học sau dự án.

- Thông tin cá nhân và danh tính của tôi sẽ được bảo mật và không tiết lộ trong bất cứ tài liệu nào liên quan đến dự án.

Tôi muốn nhận bản tóm tắt kết quả dự án

Có Không

Tôi muốn nhận một bản tóm tắt cuộc phỏng vấn của tôi:

Có Không

- Tôi muốn nhận bản báo cáo đầy đủ theo địa chỉ email cung cấp dưới đây Có Không 


\section{Appendix 5: Interview guide (in English)}

\section{Vietnamese Irregular Migration: A study on the development impacts of irregular}

economic migration

\section{Interview Guide}

1. Questions for irregular economic migrants

- Why did you decide to go abroad to work?

- How did you go?

- Why did you go abroad to work without using state-owned or private labour recruitment agency in your area?

- How long did you stay?

- Was going abroad your decision or is there any other family members or people involved in your decision-making?

- Do you know if you could be protected as a Vietnamese citizen in the destination country?

- Are you worried about your working status during your time in the destination country?

- Please tell me about your life in the destination country? Would anything change if you know of your rights while working overseas?

- What are some of the changes in your and your family's life since you've worked overseas? (Would you be able to send your child to school? Could you afford better foods? Do you or your family members work less hours?)

- What is the biggest difference in your life since you've work overseas?

- Do you notice any difference in other households who also have people working abroad like you in your community?

2. Questions for family members

- Do you contribute in the migration decision of your family member?

- What are some of the changes in your household in terms of living standards since your family member's worked overseas?

- What do you think of those changes?

- Do you notice any difference in the way other people in the community view your family?

- Do you notice any change in other families in your community who also have people working overseas like your family member?

- Does your family member send money back home? Who decides to spend it on what? Any change in the role of family members since the emigration of your family member?

3. Questions for community/ provincial leaders

- Can you tell me about the socio-economic development strategies in your province?

- What are some priorities for development in your province? 
- How is your opinion about the labour market in the area? Can you tell me about the employment/ unemployment situation in the area?

- Are there any people migrating through unofficial channels in your province? Why do you think they do that, instead of going through official channels, for example, through a labour export agency?

- Do you notice any change in your community/ province where there are people migrating unofficially/ irregularly?

- What is the most prominent difference in the communities that have people migrating irregularly?

\section{Questions for governmental officials}

- What are the priorities in terms of labour migration from Vietnam?

- What do you think of the current situation of labour migration from Vietnam?

- Do you notice a growing trend of people crossing borders as irregular migrant workers going under unofficial channels? What is your opinion about this increasing trend?

- From your experience, why do people migrate unofficially?

- Can you tell me about the current policy framework governing Vietnamese labour migration? If people migrate through unofficial channels, what is the best way to protect their rights in destination countries?

THANK YOU for your time! 


\section{Appendix 6: Interview guide (in Vietnamese)}

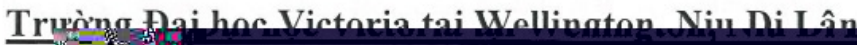

Đề tài nghiên cúru: Tác động kinh tế và xã hội của quá trình di cur lao động qua các kênh không chính thức tại Việt Nam

Danh sách câu hỏi

1. Câu hỏi dành cho người lao động di cư qua các kênh không chính thức

Xin anh/ chị cho biết lí do anh/ chị quyết định đi làm việc ở nước ngoài?

Anh/ chị đi lao động ở nước ngoài theo cách nào? Anh/ chị làm việc ờ nước ngoài trong thời gian bao lâu?

Đi làm việc ở nước ngoài là quyết định của cá nhân anh/ chị hay có các thành viên khác trong gia đình hoặc bạn bè, người quen cùng anh chị đữ ra quyết định này?

Anh/ chị có biết mình được bảo vệ quyền lợi như thế nào khi là công dâr Việt Nam đi làm việc ở nước ngoài?

Anh chị có cảm thấy lo lắng về tình trạng việc làm của mình tại nước ngoài?

Cuộc sống của anh/ chị khi đi làm ở nước ngoài như thế nào? Theo ý kiến của anh/ chị, nếu biết về các quyền lợi của công dân Việt Nam tại nước ngoài khi đi làm việc, cuộc sống của anh chị ở bên đó sẽ khác như thế nàc a?

Từ khi anh/ chị đi làm việc ở nước ngoài, anh chị nhận thấy có những thay đồi gì trong gia đình và cuộc sống của mình? (Con cái anh chị được đ học, được mua quần áo mới, đồ ăn được cải thiện, đồ đạc mới trong giء đình? Vv)

Thay đổi lớn nhất trong cuộc sống của anh chị từ khi đi làm việc ở nước ngoài?

Anh/ chị có nhận thấy các gia đình khác trong làng mình có người thân đỉ làm việc ở nước ngoài có sự thay đổi nào không?

2. Câu hỏi dành cho người nhà của lao động di cư không chính thức

Anh/ chị có tham gia đóng góp ý kiến trong quyết định đi làm việc ở nước ngoài của người nhà mình không?

Từ khi người thân của anh/ chị đi làm việc ở nước ngoài, trong gia đình mình đã có những thay đổi như thế nào trong cuộc sống?

Anh/ chị nghĩ sao về những thay đổi đó?

Hàng xóm hay những người xung quanh có đối xử với gia đình ta khác đ: không khi nhà mình có người thân đỉ làm việc ở nước ngoài? 
- Anh/ chị có nhận thấy các hộ gia đình khác trong xã/ huyện mình có người thân đi làm việc ở nước ngoài có thay đổi gì trong cuộc sống của họ không?

- Người thân của anh/ chị có gửi tiền về nhà không? Số tiền đó được dùng vào việc gì? Ai có quyền quyết định việc tiêu tiền? Trong gia đình có sự thay đổi nào về vai trò của các thành viên gia đình khi có người đi làm việc ở nước ngoài không ạ?

\section{Câu hỏi dành cho lãnh đạo xã/ huyện}

- Xin ông/ bà cho biết về kế hoạch phát triển kinh tế xã hội của địa phương?

- Địa phương của ông/ bà có ưu tiên phát triển những lĩnh vực nào?

- Xin ông/ bà đánh giá thị trường lao động và việc làm trong địa bàn mình? Tình hình việc làm và thất nghiệp ở xã mình hiện nay như thế nào?

- Trong xã của ông bà có nhiều người đi làm việc ở nước ngoài qua các kênh không chính thức không ạ? Theo ý kiến của ông/ bà, tại sao những người đó lại lựa chọn đi làm việc ở nước ngoài theo hình thức tự đi mà không thông qua các cơ quan tuyển dụng và xuất khẩu lao động?

- Ông/ bà nhận thấy những thay đồi gì trong cộng đồng làng xã của mình nơi có người đi làm việc ở nước ngoài theo các hình thức tự đi?

- Theo ông/ bà, thay đổi nào rõ rệt nhất trong làng, xã của mình từ khi có người đi làm việc ở nước ngoài theo hình thức tự đi?

\section{Câu hỏi dành cho các cán bộ nhà nước về mảng lao động di cư}

- Xin ông/ bà cho biết các ưu tiên chính sách của Việt nam trong vấn đề xuất khẩu lao động?

- Xin ông bà cho ý kiến đánh giá về tình hình xuất khẩu/ di cư lao động của Việt Nam hiện nay?

- Ông/ bà có nhận thấy tình hình gia tăng của lao động di cư theo hình thức tự đi? Ông bà có nhận định gì về tình hình này ạ?

- Theo đánh giá của ông/ bà, tại sao lao động lại lựa chọn di cư theo hình thức tự đi, qua các kênh không chính thức như hiện nay?

- Xin ông bà cho biết một vài mô hình chính sách của Việt Nam hiện nay về vấn đề quản lý xuất khẩu lao động Việt Nam? Nếu nhiều người hiện nay đang lựa chọn di cư lao động theo các hình thức không chính thức, cách tốt nhất để bảo đảm quyền lợi và bảo vệ họ là gì?

Xin cám ơn ông/ bà đã dành thời gian cho cuộc phỏng vấn này! 


\section{Appendix 7: Human Ethics Approval}

TE WHARE WRNANGA O TE UPOKO OTE IKA A MR̃U

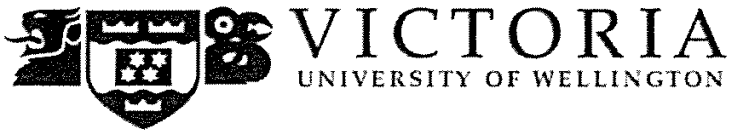

MEMORANDUM

Phone 0-4-4635205

Email stephen.marshall@vuw.ac.nz

\begin{tabular}{l|l}
\hline TO & Hang Thi Trinh \\
\hline COPY TO & \\
\hline FROM & Dr Stephen Marshall, Acting Convener, Human Ethics Committee \\
\hline DATE & 19 May 2016 \\
\hline PAGES & 1 \\
\hline & $\begin{array}{l}\text { Ethics Approval: 23044 } \\
\text { Vietnamese Irregular Migration: A study on the development } \\
\text { impacts of irregular economic migration. }\end{array}$
\end{tabular}

Thank you for your application for ethical approval, which has now been considered by the Standing Committee of the Human Ethics Committee.

Your application has been approved from the above date and this approval continues until 28 February 2017. If your data collection is not completed by this date you should apply to the Human Ethics Committee for an extension to this approval.

Best wishes with the research.

Stephen Marshall,

Acting Convener, Victoria University Human Ethics Committee 